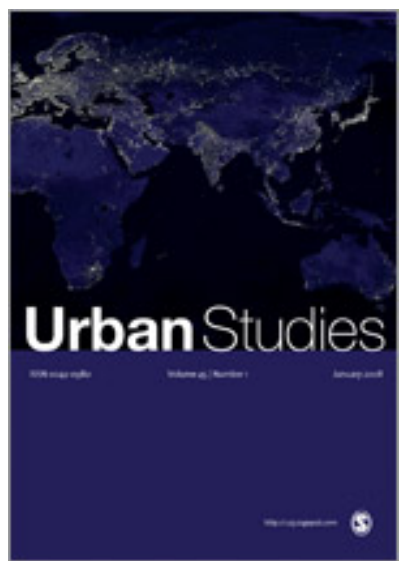

\title{
Does urban concentration matter for changes in country economic performance?
}

\begin{tabular}{|c|c|}
\hline Journal: & Urban Studies \\
\hline Manuscript ID & CUS-093-20-02.R3 \\
\hline Manuscript Type: & Article \\
\hline $\begin{array}{l}<b>\text { Discipline: Please select a } \\
\text { keyword from the following } \\
\text { list that best describes the } \\
\text { discipline used in your paper.: }\end{array}$ & Economics \\
\hline $\begin{array}{l}\text { World Region: Please select } \\
\text { the region(s) that best reflect } \\
\text { the focus of your paper. } \\
\text { Names of individual countries, } \\
\text { cities \& economic groupings } \\
\text { should appear in the title } \\
\text { where appropriate.: }\end{array}$ & Not Applicable \\
\hline $\begin{array}{r}\text { Major Topic: Please identify } \\
\text { up to } 5 \text { topics that best } \\
\text { identify the subject of your } \\
\text { article.: }\end{array}$ & Agglomeration/Urbanisation, Development, Economic Processes \\
\hline $\begin{array}{l}\text { You may add up to } 2 \text { further } \\
\text { relevant keywords of your } \\
\text { choosing below: }\end{array}$ & Long-run economic dynamics, Cross-country analysis \\
\hline
\end{tabular}

\section{SCHOLARONE \\ Manuscripts}




\title{
Does urban concentration matter for changes in country economic performance?
}

\begin{abstract}
This paper uses a novel, globally-harmonised city-level dataset — with cities defined at the Functional Urban Area (FUA) level - to revisit the link between urban concentration and country-level economic dynamics. The empirical analysis, involving 108 low- and high-income countries, examines how differences in urban concentration impinge on changes in employment, Gross Domestic Product (GDP) per capita, and labour productivity at country level over the period 2000-2016. The results indicate that urban concentration reduces employment growth, but increases GDP per capita and labour productivity growth. The returns of urban concentration are higher for high- than for low-income countries, and are mainly driven by the 'core' of FUAs, rather than by sub-urban areas.
\end{abstract}

Keywords: Urban concentration; Long-run economic dynamics; Employment growth; GDP per capita growth; Labour productivity growth; Cross-country analysis.

JEL Codes: E24; O47; O57; R12.

\section{Introduction}

Today about $55 \%$ of world population lives in urban areas. The concentration of the world population in cities is the consequence of rapid urbanisation: between 1950 and 2018 the population living in cities rose from 0.75 to 4.22 billion. Rapid urbanisation has been particularly rife in developing countries. In 1950, 59.4\% of the world urban population lived in developed world cities. This share had declined to a mere $23.6 \%$ by 2018 . Urban growth has also been more intense in large cities. The population living in cities of more than 5 million rose from 162 to 855 million between 1970 and 
2018. Once again, this rise was far more pronounced in low- than in high-income countries. During this period, the rate of population growth in large cities was 4.7 times higher in the former than in the latter (United Nations, 2019).

This global and rapid move towards cities and the corresponding increase in urban concentration have attracted considerable attention. Urban economists and economic geographers have investigated extensively the economic impact of cross-country differences and changes in urban concentration and hierarchy. The dominant view is that economic dynamism is greater in countries with highly concentrated urban structures, with a limited number of very large cities (e.g., Melo et al., 2009; Rosenthal and Strange, 2004). However, this view has been challenged by more recent scholarly work. This research suggests that there is simply not enough evidence to assert that urban concentration drives growth in all countries. It is increasingly posited that the link between urban concentration and economic performance is highly context-specific and related to variations in economic development levels across countries (e.g., Berdegué et al., 2015; Brülhart and Sbergami, 2009; Castells-Quintana, 2017; Frick and Rodríguez-Pose, 2018a; Henderson, 2003).

This paper revisits this debate, addressing the question of whether greater urban concentration leads to improvements in overall economic dynamism. It provides new empirical insights on the longrun effects of urban concentration on employment, wealth, and productivity growth at country level. To do so, it uses a novel, globally-harmonised city-level dataset covering 108 high- and low-income countries over the period 2000-2016. The degree of urban concentration —operationalised by means of a Herfindahl-Hirschman Index (HHI) — is defined at the beginning of the growth period. Different measures of urban concentration are regressed on different types of economic performance, controlling for a large set of country-specific economic, demographic, and geographic characteristics known to affect employment, Gross Domestic Product (GDP) per capita, and productivity growth. We also test for causality and endogeneity issues by means of an instrumental variable (IV) approach -which exploits cross-country variations in terms of land area equipped for irrigation in the year 1900.

The results of the analysis suggest the existence of a negative effect of urban concentration on employment growth. In contrast, urban concentration positively affects GDP per capita and labour productivity growth. These general findings depend, however, on the level of development of the countries considered and the threshold values of Functional Urban Areas' (FUA) population size. Urban concentration propels growth to a greater extent in high-income countries than in low-income ones. Economic performance is also higher in countries with high-density 'cores' than in those with more low-density urban zones.

The paper presents three key novelties with respect to previous research. First, it is among the first to exploit city population data from the new Global Human Settlement Layer (GHSL) database, 
recently developed by the Joint Research Centre and the Directorate-General for Regional and Urban Policy of the European Commission. This new database allows for a considerably more granular approach than previous city-level databases dealing with 'urban concentration'. The logic behind this database is that the traditional concept of 'city' has changed significantly. Cities have augmented their sphere of influence, becoming broader 'functional' — rather than purely administrative — urban areas (Dijkstra et al., 2018). The use of a functional definition allows for a more adequate measurement of cities, going beyond traditional administrative boundaries that follow diverse national definitions, and which, frequently, do not coincide with the physical space where social and economic activities take place within cities (Ahrend et al., 2017). The GHSL database has the great advantage of employing a globally-harmonised definition of FUAs, which allows for a direct comparison of the degree of urban concentration among countries worldwide.

Second, we complement previous evidence on the relationship between urban concentration and economic dynamics at country-level — which was commonly based on short-run analyses — by explicitly focusing on the long term. In doing this, we provide novel insights on the urban concentration-economic growth nexus, by accounting for the heterogeneity between low- vs. highincome countries, and between high-density (core) and low-density (peripheral) urban zones within FUAs. On the one hand, we assess the interplay between the national concentration-dispersion pattern and the monocentric-polycentric internal spatial structure of urban agglomerations. On the other, we also examine if there is an 'optimal' size of FUAs for agglomeration economies to materialise.

Finally, we provide a comparative analysis involving three different economic dimensions: employment, GDP per capita — used as a proxy for wealth—, and labour productivity growth. This implies going beyond the traditional focus on GDP per capita (e.g., Bertinelli and Strobl, 2007; Castells-Quintana, 2017; Frick and Rodríguez-Pose, 2016, 2018a), in order to evaluate whether and how the economic returns of urban concentration vary with respect to different economic dimensions.

The aim is to push the boundaries of existing knowledge, while providing policymakers with a more comprehensive picture for evaluating how country-level variation in urban concentration may affect the returns of development and growth policies.

The rest of the paper is organised as follows. The following Section discusses the theoretical and empirical literature on the relationship between urban concentration and economic growth. The third Section presents the empirical model. The fourth Section presents the results, which are discussed in the fifth Section. The sixth Section concludes and draws some policy implications.

\section{Urban concentration and national economic performance: a view from the literature}


Starting with Marshall (1890), many scholars have emphasised the growth-enhancing powers of the geographic concentration of economic activities. In the Marshallian tradition, the agglomeration of firms and their workers creates a fertile ecosystem for the circulation of ideas and knowledge thanks to labour market pooling, proximity to (specialised) suppliers, and inter-sector linkageswhich, in turn, enhances overall firm-level efficiency (Ciccone and Hall, 1996; Duranton and Puga, 2004; Rosenthal and Strange, 2004). This basic idea was later formalised by the New Economic Geography (NEG) literature (Krugman, 1991), that pointed to increasing returns to scale, reduction of transport costs, and market access as additional urban growth drivers. All these factors led to the formation of a dominant view: the concentration of more dynamic firms in cities creates economic dynamism in urban environments and, especially, in large metropolises (Glaeser et al., 1992; Henderson et al., 1995; Puga, 2010).

From this perspective, the city represents the space where positive agglomeration externalities emerge and intensify, as (traditional) manufacturing activities meet tangible and intangible assets linked to both business services and a creative atmosphere typical of a diversified urban structure (Florida, 2002; Jacobs, 1969). The presence of individuals from different backgrounds and with different skill levels, together with the availability of physical infrastructures and of public and private services concentrated in well-defined urban agglomerates, turn cities into the motors of modern economic dynamism and growth (Duranton, 2015; World Bank, 2009).

Drawing on these theoretical insights, urban economists have focused on the micro-foundations of agglomeration economies at city level, providing evidence of a productivity premium for large and high-agglomerated cities relative to smaller cities, towns, and rural areas in low-density environments (Ciccone and Hall, 1996; Duranton and Puga, 2004; Melo et al., 2009; Rosenthal and Strange, 2004). The NEG literature, however, has also highlighted how productivity follows an inverted U-shape function with respect to city size. From this perspective, an excessive concentration of economic agents (population, workers, firms) in cities can result in agglomeration diseconomies - e.g., congestion, pollution, and high land rents (Duranton and Puga, 2004).

Agglomeration diseconomies can be addressed through migration processes connecting cities of different sizes. The interplay between centripetal and centrifugal agglomeration forces determines the location of economic activities within a country (Fujita et al., 1999; Krugman, 1991). Centripetal forces - through positive agglomeration externalities - further incentivise the concentration in large (and growing) cities. Centrifugal forces - driven by negative agglomeration externalities - push for dispersion, such that migration processes occur until an 'optimal' spatial distribution of agents is reached (Bertinelli and Black, 2004). In particular, migration processes occur at two spatial levels. They happen across cities, leading to national polycentric structures dominated by (almost) equalsized cities, and within large cities, favouring the formation of sub-centres functionally connected 
with urban 'cores'. These sub-centres borrow agglomeration benefits arising from a large and functionally-integrated urban area, but without suffering the productivity slowdowns associated with agglomeration diseconomies ( $\mathrm{Li}$ and Liu, 2018; Shen et al., 2019).

Overall, from a theoretical viewpoint, the adjustment process should lead to a national spatial structure where agents are distributed efficiently over space, such that productivity is maximised both at micro and country level (Duranton and Puga, 2004). However, this theoretical mechanism is far from being empirically validated. Political interests of primary cities, weak infrastructure endowments in more remote and/or less dense locations, and the motivations of individuals may limit or prevent migration processes from congested large cities towards less dense locations. Indeed, not only metropolises in developed countries have become larger and more concentrated over the last decades, but also new ones have emerged mostly in developing countries (Frick and Rodríguez-Pose, 2016, 2018a; United Nations, 2019).

The city-level evaluation of agglomeration economies and diseconomies needs, however, to be complemented by research accounting for the 'overall' spatial structure of a country. There are considerable risks involved in linking a country's economic performance to the productivity of a single or few high-agglomerated cities. The way economic activity is spatially distributed within a country and, consequently, the national degree of concentration of population and economic activity, can have important implications for overall economic development (Frick and Rodríguez-Pose, 2016).

Building on this rationale, many past contributions have analysed the relationship between urban concentration and economic growth at country level (e.g., Ahrend et al., 2017; Atienza and Aroca, 2013; Berdegué et al., 2015; Bertinelli and Strobl, 2007; Bloom et al., 2008; Brülhart and Sbergami, 2009; Castells-Quintana, 2017; Frick and Rodríguez-Pose, 2018a; Henderson, 2003; Lewis, 2014). Most research has underlined the existence of a positive link between urban concentration and economic performance, especially when considering developed and high-income countries (e.g., Melo et al., 2009; Rosenthal and Strange, 2004).

However, there is no complete agreement on the subject. While some contributions underline how urban concentration significantly boosts economic growth up to certain thresholds of economic development (e.g., Brülhart and Sbergami, 2009; Henderson, 2003), or find no evidence of urbanisation-related benefits for economic growth (e.g., Bloom et al., 2008), some more recent scholarly work concludes that the urban concentration-economic growth relationship is highly context-specific, especially when confronting developed vs. developing countries. This is because, although there has been a global tendency towards urban concentration, the paths towards urbanisation have differed greatly between high- and low-income countries. Developed and highincome countries have experienced a process of relative decentralisation of the urban population, 
driven mostly by a physical and functional expansion of the 'traditional' city towards enlarged FUAs. This process has entailed a movement of individuals and economic activities from urban cores to suburban areas within FUAs (Veneri, 2018). Developing and low-income countries, by contrast, have witnessed hefty migration processes from rural to urban areas. The result has been a rapid acceleration of urbanisation with a greater concentration of population within high-monocentric 'megacities' (United Nations, 2019). These processes stand out in the work of Castells-Quintana (2017), who finds that urban concentration pushes short-run GDP per capita growth in developed countries, while this relationship depends on access to basic infrastructures in developing countries. Similarly, Frick and Rodríguez-Pose (2018a) uncover that urban concentration is at the root of short-run GDP per capita growth in developed countries only.

The growing number of empirical studies focusing on the economic returns of urban concentration and the recent trends in urban dynamics in the developed and developing worlds are casting increasing doubts into the hitherto dominant notion of a positive link between urban concentration and economic growth. There are also other factors that are stoking interest on the topic. First, most previous research has focused on the short-term relationship between urban concentration and GDP per capita growth. Second, limited evidence exists on both the returns of urban concentration on other economic dimensions (e.g., employment and labour productivity), and its long-run effects. Third, the different urbanisation paths followed by high- and low-income countries demand a more detailed analysis on the potential economic growth returns of urban concentration in these two types of economies. Different agglomeration-related economic returns for high- vs. lowincome countries can be the result of their diverse — and structural — ability to manage the potential negative externalities arising from urban concentration, such as crowding, environmental degradation, pollution, and over-priced housing markets (Bloom et al., 2008; Rodríguez-Pose and Storper, 2020).

Hence, novel empirical analyses on the link between urban concentration and economic performance are required, especially in light of the attention policymakers are paying to urbanoriented development and growth strategies. The urban concentration-growth nexus has relevant economic policy implications, as long as a 'growth-inequality' trade-off exists and may force policymakers to choose between pushing overall economic growth and promoting socio-economic cohesion (Brülhart and Sbergami, 2009; Martin, 1999; Martin, 2008). We contribute to this debate by analysing the short- and long-run effects of urban concentration on employment, wealth, and labour productivity growth, distinguishing explicitly between low- vs. high-income countries. We provide a more comprehensive picture of the growth returns of urban concentration by evaluating also the interplay between the national concentration-dispersion pattern and the monocentric- 
polycentric internal spatial structure of urban agglomerates. We also examine whether an 'optimal' city size exists for agglomeration economies and diseconomies to materialise.

\section{Empirical framework}

\section{Empirical model}

The relationship between urban concentration and long-run change —over the period 2000-2016of employment, GDP per capita, and labour productivity at country level is assessed using the following cross-sectional empirical growth equation:

$\Delta Y_{c}=\alpha+\beta \log \left(Y_{c}\right)+\gamma$ Urban Concentration $_{c}+\sum_{k=1}^{K} \delta_{k} X_{c}^{k}+\boldsymbol{\theta}_{r}+\varepsilon_{c}$

where the dependent variable is defined as $\Delta Y_{c}=\frac{1}{T-t}\left[\log \left(Y_{c}^{T}\right)-\log \left(Y_{c}^{t}\right)\right]$ and denotes the growth rate of either employment, GDP per capita, or labour productivity — defined as GDP per employeebetween $t=2000$ and $T=2016$ in country $c=1, \ldots, 108$. The right-hand side of Equation (1) includes: a constant term $(\alpha)$; the initial (year 2000) growth value of either employment, GDP per capita, or labour productivity to control for convergence (Barro, 1991); the initial growth variable for urban concentration; the vector $X_{c}^{k}$ of country-specific control variables, defined either as average values over a pre-2000 period or as time invariant, depending on their nature; the vector $\boldsymbol{\theta}_{r}$ of macroregion dummy variables - defined for Asia, Africa, Europe, Latin America and the Caribbean, North America, and Oceania, according to the United Nations' (UN) taxonomy - aimed at capturing nonobservable characteristics which are common to all the countries located within the same macroregion; and the error term, $\varepsilon_{c}{ }^{1}$

The key explanatory variable depicts the degree of concentration of urban population in a country. The variable is defined using urban population data derived from the GHSL database. This database provides detailed information at FUA level for the population residing in high-density urban areas (i.e., the 'core' of FUAs), low-density urban areas (i.e., the suburbs), and the rural outskirts of each FUA in a country. Following Frick and Rodríguez-Pose (2018a), the national concentration of urban population is operationalised through an HHI, which is defined as follows:

Urban Concentration $_{c}=\sum_{\substack{f=1 \\ f \in c}}^{F}\left(\frac{\text { Urban Population }_{f, c}}{\sum_{\substack{f=1 \\ f \in c}}^{F} \text { Urban Population }_{f, c}}\right)^{2}$ 
where Urban Population $f, c$ denotes the urban population of FUA $f$ in country $c$ in the year 2000, with urban population defined as the population residing in low- and high-density urban areas of a FUA. The urban concentration variable ranges in the interval $[1 / F, 1]$. The higher the value of the index, the higher the degree of concentration of urban population in a country. The interpretation of the index is straightforward: a positive coefficient indicates that urban concentration pushes national economic performance. ${ }^{2}$

The vector $X_{c}^{k}$ of country-specific controls includes a set of variables entering the right-hand side of all the three versions of Equation (1) for employment, GDP per capita, and labour productivity growth. This set includes: (i) the Gross Fixed Capital Formation to GDP ratio, defined as the average value over the period 1990-2000, capturing investments in the national economy; (ii) the share of government consumptions, defined as the average value over the period 1990-2000, depicting the weight of the public sector in the national economy; (iii) the oil rents to GDP ratio, defined as the average value over the period 1990-2000, reflecting the dependence on oil exports; (iv) the openness of the national economy, calculated as the sum of exports to GDP and imports to GDP ratios, defined as the average value over the period 1990-2000; (v) the share of high-tech manufacturing exports to total manufacturing exports, defined as the average value over the period 1990-2000, denoting a country's technological level; (vi) a dummy variable for high-income countries, defined according to the World Bank's taxonomy; (vii) population density, defined as total population per square kilometre, averaged over the period 1990-2000, to proxy for the overall degree of concentration of individuals in a country; (viii) the average years of schooling, defined as the average value for 1990, 1995, and 2000, capturing levels of education; (ix) government effectiveness, defined as the average value for 1996, 1998, and 2000, representing the quality and credibility of national institutions; (x) the country' surface, to proxy for its size; (xi) a dummy variable for island countries; (xii) a dummy variable for landlocked countries; (xiii) the geographic coordinates (latitude and longitude) of a country's centroid, to control for geographic heterogeneity. In addition, the employment growth equation is specified by adding to the vector $X_{c}^{k}$ a measure of GDP per capita - defined as the average value over the period 1990-2000 — as an indicator of the overall national wealth. The GDP per capita and labour productivity growth equations contain in the vector $X_{c}^{k}$ a variable representing the level of employment in a country, measured as its average value over the period 1991-2000. ${ }^{3}$

\section{Estimation approach}

We adopt, following Barro (1991), an Ordinary Least Squares (OLS) estimation approach. However, the potential endogeneity of the urban concentration variable can bias the OLS estimates. Endogeneity may emerge for several reasons, including reverse causality (the urban structure of a country can be the result of its economic performance and dynamism, rather than the other way round) 
and measurement errors (related to difficulties in identifying the proper geographic unit capturing the 'urban space') (e.g., Brülhart and Sbergami, 2009; Castells-Quintana, 2017; Frick and RodríguezPose, 2018a; Henderson, 2003). We address potential endogeneity problems by means of a TwoStage Least Squares (TSLS) estimator.

The proposed identification strategy exploits cross-country variations in the irrigated land area in 1900 to instrument for the current degree of urban concentration at country level. The rationale behind the chosen IV is that improvements in agricultural productivity could have contributed to shape the 'modern' process of urbanisation and, consequently, the current urban structure of a country. As discussed by Motamed et al. (2014), among others, first-nature geographic factors, such as soil fertility, represented key forces that favoured the establishment of cities in the past. Historically, cities have been set up in accessible locations that could act as markets for the agricultural production of neighbouring areas. Being surrounded by fertile land was also essential to satisfy the nutrition needs of large urban populations. The availability of fertile land would therefore have favoured the concentration of rural population and the formation of cities. Subsequent improvements in agricultural productivity and an increased availability of agricultural products, together with improvements in transportation, would have freed part of the agricultural workforce to be used in non-agricultural production activities, inducing migration processes from rural areas to nearby cities (Michaels et al., 2012; Motamed et al., 2014). Hence, interventions aimed at increasing agricultural production — such as, for example, improvements in irrigation infrastructures - could have, first, led to an increase in the density of rural population in response to rises in agricultural productivity, followed by a push towards urban centres. In such a scenario, improvements in agricultural activities could be at the root of the emergence of cities and of the concentration of population in certain cities (Frick and Rodríguez-Pose, 2018a). The IV capturing a country's irrigated land area in 1900 can therefore be considered a good predictor of current urban concentration in a country. The validity of the identification strategy is guaranteed by the fact that the IV is likely to be exogenous to national growth rates in employment, GDP per capita, and labour productivity taking place more than a century later.

The data on irrigated land area are drawn from the global Historical Irrigation Dataset, which provides estimates — based on sub-national irrigation statistics collected from various sources - of the time development of the irrigated land between 1900 and 2005 at a 5 arcmin resolution — see Siebert et al. (2015) for details.

\section{Results}

Urban concentration pushes wealth and productivity but harms employment growth 
Table 1 reports the results of the OLS — see columns (1), (3), and (5) - and TSLS - see columns (2), (4), and (6) — estimation of Equation (1). ${ }^{4}$

The OLS results suggest that urban concentration is negatively but negligibly associated with employment growth. By contrast, a positive and statistically significant association is found with both GDP per capita and labour productivity growth. They also indicate that convergence in all three economic dimensions considered has been the norm in recent years.

However, as previously discussed, the OLS estimation of the urban concentration parameter can be biased by endogeneity. The TSLS estimation highlights that the IV capturing irrigated land area in 1900 has a good predictive power, as the first-stage F statistic on the excluded IV is higher than the conservative cut-off value of 10 in all the estimated specifications. Particularly, the TSLS results indicate that urban concentration increased both GDP per capita and labour productivity growth. This effect is strongly statistically significant. In contrast, urban concentration reduced employment growth. Hence, in the long run, higher urban concentration leads to higher economic growth and productivity, but weakens the labour market by reducing the capacity to create new jobs.

At first glance these results may seem puzzling, as the expectation, based on the dominating urban economics and NEG theories, is that urban concentration - depending on the prevalence of agglomeration economies or diseconomies - would either positively or negatively affect all three economic dimensions. However, this may not always be the case. ${ }^{5}$ Agglomeration externalities can positively affect productivity and wealth, while, simultaneously, destroy jobs. For example, positive agglomeration economies can trigger higher innovation, which, in turn, can push firms to shed employment while improving production processes. New production methods based on efficiencyenhancing technologies (e.g., robotisation) tend to be more capital than labour intensive, leading to productivity increases and, potentially, to labour substitution. Moreover, positive agglomeration economies drive inward migration allowing firms to choose from a pool of high-quality and highlyproductive workers (Francis, 2009; Zenou, 2009). The concentration of high-productivity workers in the city will further increase overall productivity, but also make prices and living costs soar in core cities. This may drive away and/or prevent lower-skilled workers from living in large city centres, pushing them to the urban fringes or preventing them from joining the large city worker pool altogether (Rodríguez-Pose and Storper, 2020). ${ }^{6}$

\section{[--- Table 1 about here ---]}

\section{The returns of urban concentration are greater in high-than in low-income countries}

The most recent empirical literature has emphasised how the short-run returns of urban concentration on economic performance are not homogeneous across different types of countries and, in particular, 
between high- and low-income countries. Following this rationale, the TSLS estimation of Equation (1) is replicated by splitting the sample into low- and high-income countries to evaluate the extent to which the economic returns of urban concentration depend on a country's development level.

Table 2 reports the TSLS estimates of Equation (1). The results reveal that the negative longrun returns of urban concentration on employment are only statistically significant for high-income countries. The agglomeration effects linked to urban concentration, therefore, do not work in the same way in both groups of countries. By contrast, positive and statistically significant effects of urban concentration on GDP per capita and labour productivity growth are in place in both low- and highincome countries. However, the estimated coefficients show that the positive economic returns of urban concentration are considerably higher for high- than for low-income countries in the long run. That the returns of urban concentration on wealth and labour productivity are higher in high- than low-income countries and that labour-market diseconomies are more prevalent in high-income countries may come down to different life-cycle processes in cities depending on their level of development (Shen et al., 2019). It may be the case that large urban agglomerations in high-income countries have already reached a turning point, with centrifugal forces playing a stronger role and undermining centripetal ones. By contrast, the 'newer' megacities in low-income countries can benefit from increasing agglomeration economies, with agglomeration diseconomies still playing a limited role (Brülhart and Sbergami, 2009). In this respect, the positive wealth and productivity returns associated with agglomeration economies may have not yet peaked, while the negative employment returns can still emerge. A further explanation could be related to differences in technological development between low- and high-income countries. Agglomeration-related technological progress drives up productivity and wealth, but depresses employment to a greater extent in high- than in low-income countries. This may be related to the prevalence in high-income country urban agglomerations of service- and information-based activities - characterised by capital intensive, high value-added sectors - triggering a greater concentration of highly productive, but also higher-wage workers in big developed cities. This concentration builds up, once again, productivity and wealth without necessarily requiring a larger labour force. In contrast, labour-intensive activities remain dominant in most low-income country megalopolises, meaning that the productivity and wealth returns are lower, while those of employment higher.

\section{[--- Table 2 about here ---]}

To understand better whether and how time matters in evaluating the economic returns of urban concentration, the TSLS estimation of Equation (1) for low- and high-income countries is replicated considering two shorter time horizons of five and eight years, respectively. This exercise aims at 
providing a comparison with the results of Frick and Rodríguez-Pose (2018a), who analyse the shortrun, five-year relationship between urban concentration and GDP per capita growth in developed vs. developing countries.

Table 3 reports the TSLS results. Two interesting insights emerge. First, the time horizon considered in analysing the growth returns of urban concentration matters. The short- and mid-term results differ significantly with respect to the long-run estimates of Table 2 . Second, it takes time for urban concentration to produce its effects on the economy of a country. The five-year results (upper panel of Table 3) suggest that urban concentration has a positive and statistically significant impact - albeit weaker than in the long run - on the short-run growth of GDP per capita and labour productivity in high-income countries only. In this time horizon, urban concentration remains completely irrelevant for low-income countries. However, as the time dimension increases to eight years (lower panel of Table 3), the productive efficiency of low-income countries marginally benefits from urban concentration. The economic returns of urban concentration are, thus, weak and affect economic trajectories more in the long- than in the short-run. This is particularly the case for lowincome countries.

[--- Table 3 about here ---]

\section{The growth returns of urban concentration are driven by the urban 'core' of FUAs}

One important new dimension of the analysis is the focus on whether urban concentration produces different economic effects when distinguishing between the low- and high-density parts of FUAs, i.e., between the core of cities and the suburbs. The GHSL database contains disaggregated data on the population residing within both the high-density centre (i.e., the 'core') and the low-density urban area (i.e., the 'suburb') of FUAs. This allows us to calculate the HHI to capture urban concentration considering the urban population residing in these two urban zones separately. This exercise accounts for intra-FUA heterogeneity, evaluating the interplay between the national concentration-dispersion pattern and the monocentric-polycentric internal spatial structure of urban agglomerates ( $\mathrm{Li}$ and Liu, 2018).

Table 4 reports the TSLS estimates of Equation (1) considering the two variables for urban concentration in low- and high-density urban areas separately. The negative long-run returns of urban concentration on employment growth and the positive returns on GDP per capita and labour productivity growth are higher for high-density than for low-density urban zones. This evidence suggests that agglomeration-related advantages and congestion effects arise from 'true' urban cores, while the prevalence of suburbs diminishes the economic returns of urban concentration. The concentration of (self-selected) highly-productive, high-wage workers in high-density urban cores 
appears as a key growth-enhancing factor for overall productivity and wealth. Simultaneously, greater suburbanisation does not reduce the negative employment growth returns of excessive urban concentration. The presence of large, low-density suburbs also contributes —albeit to a lesser extent than high-density cores - to overall productivity and wealth growth through the generation of additional positive agglomeration externalities. In any case, the negative employment growth effects remain. This may be because the spatial evolution of FUAs from a monocentric to a polycentric internal structure is far from complete. The ongoing re-allocation processes of low-wage workers and unemployed individuals from city centres to suburbs could go a long way in explaining negative employment effects in the urban 'core'. It may also be the case that suburbs with still limited infrastructure endowment and weaker services than 'cores' may have not yet fully maximised their economic potential - e.g., in terms of their capacity to attract firms fleeing the high prices of urban centres or of generating start-ups. Hence, their job creation capacity is not strong enough to counterbalance the arrival of individuals fleeing expensive urban centres. The overall picture suggests that positive agglomeration economies related to urban concentration at country level can be maximised through a spatial re-configuration process of economic activities within individual FUAs.

\section{[--- Table 4 about here ---]}

\section{Detecting the size-related effects of FUAs}

Finally, the TSLS estimation of Equation (1) is replicated considering a series of urban concentration variables defined over subsets of FUAs identified with respect to population threshold values. This exercise considers the size-related effects of FUAs, testing for possible aggregation biases (Rosen and Resnick, 1980). Specifically, the HHI is calculated including FUAs with population greater than or equal to $50,000,100,000,150,000,200,000$, and 250,000 inhabitants.

Table 5 reports the TSLS results. They suggest two interesting insights. First, the magnitude of the estimated coefficients of the urban concentration variables decreases as the population size of the FUAs increases. The positive and negative urban concentration effects on long-run growth are consequently lower in the presence of highly concentrated urban structures dominated by large urban areas. Second, the negative effect of urban concentration on long-run employment growth becomes negligible above a threshold value of 150,000 inhabitants. This implies that job market-related congestion effects are almost absent in contexts where the urban population is concentrated in relatively large urban areas. In contrast, the estimated positive effects of urban concentration on both GDP per capita and labour productivity growth remain highly statistically significant with respect to all the cut-off values of population size —although decreasing in magnitude. Furthermore, the difference in estimated coefficients between cut-off values becomes statistically negligible at a 
threshold value of 150,000 inhabitants. These results complement those reported in Table 4 . They also add new insights on the 'optimal' size of FUAs at which agglomeration economies arising from a highly concentrated national urban structure push overall productivity and wealth growth, before agglomeration diseconomies become detrimental for employment growth. The picture emerging from Table 5 suggests that labour market-related diseconomies are active in smaller FUAs but affect larger ones less. Drawing on the previous arguments, a possible explanation could be related to the fact that larger FUAs - those above 200,000 inhabitants - have largely developed polycentric internal spatial structures with well-functioning — and functionally integrated - suburbs, resulting in a greater within-city spatial equilibrium. Smaller FUAs, instead, are behind in the city life-cycle process. Thus, the combination of ongoing adjustment processes in terms of migration into and out of the urban 'core', together with less efficient services and infrastructure endowments in still-evolving suburbs, could help explain the presence of labour market-related diseconomies.

\section{[--- Table 5 about here ---]}

\section{Discussion}

The empirical results presented in the previous Section corroborate some existing knowledge on the economic returns of urban concentration, while simultaneously providing novel insights on the casual effect of urban concentration on employment, wealth, and labour productivity growth.

The analysis offers a comprehensive assessment of whether having highly concentrated national urban structures is a driver of economic performance across four main dimensions. First, we provide a comparative analysis of the long-run growth returns of urban concentration on employment, wealth, and labour productivity. This analysis complements previous research that focused almost exclusively on the short-run effects of urban concentration on GDP per capita growth (e.g., Bertinelli and Strobl, 2007). Second, and following recent investigations (e.g., Castells-Quintana, 2017; Frick and Rodríguez-Pose, 2018a), we distinguish between low- and high-income countries to account for both heterogeneity in development levels (e.g., Henderson, 2003) and variations in urbanisation paths between developed and developing countries (e.g., United Nations, 2019) in the short- and long-run. Third, we evaluate the interplay between the national concentration-dispersion pattern and the monocentric-polycentric internal spatial structure of urban agglomerations, expecting to find differences in the spatial adjustment processes of economic activities both across cities and between the urban 'core' and the suburbs of a city (e.g., Bertinelli and Black, 2004; Li and Liu, 2018; Shen et al., 2019). Finally, we analyse population threshold values to evaluate whether an 'optimal' city size exists for the emergence and interplay of agglomeration economies and diseconomies (e.g., Frick and Rodríguez-Pose, 2018b). 
Considering the first two dimensions, we find that high levels of urban concentration have opposing growth returns on employment vs. wealth and labour productivity. Urban concentration has a negative impact on employment growth in high-income countries only. However, this negative impact is only in evidence in the long run. By contrast, urban concentration has a positive effect on both wealth and labour productivity growth, both in low- and high-income countries. These positive growth returns of urban concentration, however, take some time to materialise, especially in lowincome countries. Our results corroborate previous evidence according to which urban concentration has positive short-run effects on GDP per capita growth in high-income countries only (e.g., CastellsQuintana, 2017; Frick and Rodríguez-Pose, 2018a). But we also find that also low-income countries benefit from urban concentration in terms of wealth growth, although this only happens in the long run. In addition, the positive urban concentration returns on labour productivity growth in low-income countries take time to materialise (i.e., eight-year period). By contrast, they are observable already over a short-run (i.e., five-year) period in high-income countries.

Overall, we find that the growth returns of urban concentration are greater for high- than for low-income countries, and that the impact of urban concentration on economic performance varies depending on the time horizon and the type of economic output considered. We shed further light on the negligible (Frick and Rodríguez-Pose, 2018a) or negative (Castells-Quintana, 2017) returns of urban concentration on wealth and productivity in low-income countries, which seem to be predominantly a short-run phenomenon, and we add new evidence on how urban concentration shapes employment trends.

Concerning the third and fourth dimensions, we provide new evidence suggesting that the growth returns of urban concentration are primarily driven by the urban 'core' of FUAs. Indeed, the negative long-run returns of urban concentration on employment growth, and the positive returns on GDP per capita and labour productivity growth, are higher for high-density than for low-density areas within FUAs. We also uncover that the growth returns of urban concentration diminish as the population size of FUAs increases. These results corroborate previous evidence indicating that the positive urban concentration effects on wealth growth are lower in countries with highly concentrated urban structures dominated by large urban areas (e.g., Frick and Rodríguez-Pose, 2016, 2018b). They also confirm this pattern with respect to labour productivity growth and provide new evidence suggesting that the negative urban concentration effects on employment growth become negligible above a threshold value of 150,000 inhabitants. Altogether, these findings indicate that the positive and negative country-level growth returns of highly concentrated national urban structures can be balanced only if adjustment processes occur both across cities of different size, and between welldeveloped urban 'cores' and suburbs within FUAs. 


\section{Conclusions}

This paper has investigated the relationship between urban concentration and growth of employment, GDP per capita, and labour productivity over the period 2000-2016, using a sample of 108 low- and high-income countries. It has exploited novel information on urban population residing in FUAs using a new, globally-harmonised database. The aim was to revisit previous research on the short-run returns of urban concentration on GDP per capita growth by focusing on the long-run returns of urban concentration on three different economic dimensions (employment, GDP per capita, labour productivity), accounting for the heterogeneity between low- and high-income countries, as well as for differences in the spatial structure of FUAs.

Overall, the empirical analysis suggests a negative effect of urban concentration on employment growth and a positive one on GDP per capita and labour productivity growth. However, these results are highly dependent on the level of development of the country considered. The returns of urban concentration are greater for high- than for low-income countries and become stronger over the long run. In addition, the growth returns of urban concentration are higher for countries with a prevalence of high-density urban cores than for those dominated by low-density suburbs. They also become stronger in highly concentrated national urban structures made up by relatively small urban areas.

Our results in part confirm previous research, but also provide novel insights. In particular, they suggest that the dimension and direction of urban concentration returns vary according to the economic dimension evaluated, the type of country considered, the time horizon analysed, and the urban thresholds applied in the analysis.

Can policy implications be derived from these results? While prescribing more investment on education or innovation is relatively straightforward, recommending that countries should alter urban structures that have been built over long-term historical periods is far more difficult and could be counterproductive. However, it is important to recognise that different national forms and degrees of urban structure and concentration contribute to shape country-level economic trajectories and may thus affect the impact of other policies. Our results show how any growth strategy needs to consider that variations in urban structures may result in potentially opposing effects on different economic dimensions. They also suggest that the level of development of a country matters in the role cities play in national economic performance. Hence, it may be the case that labour market-related measures are more needed in urban areas in high-income countries, and especially in those with highly agglomerated urban areas at the top of the urban hierarchy, if we are to counterbalance agglomeration diseconomies limiting job creation and increasing inequality. By contrast, in developing countries measures aimed at reinforcing the labour market in primary cities — for example, by providing better urban infrastructure and services to accommodate high rural-urban migration (e.g., Castells-Quintana, 2017) - may be more effective. 


\section{Acknowledgements}

We are grateful to the Editor in charge, Markus Moos, and to four anonymous reviewers for their insightful comments and suggestions to our paper. We are also grateful to Lewis Dijkstra (Directorate-General for Regional and Urban Policy of the European Commission), and to participants to the $59^{\text {th }}$ Congress of the European Regional Science Association (Lyon, 2019) for valuable comments and feedbacks. This research has benefitted from the financial support of the Directorate-General for Regional and Urban Policy of the European Commission. All errors and omissions are our own.

\section{Endnotes}

1. Online Appendix A presents information on the sample, the data, and the cleaning procedure. It also provides descriptive statistics and the correlation matrix of the variables used in the empirical analysis.

2. Other measures of urban concentration alternative to the HHI have been proposed in the literature. These fundamentally include primacy (share of the largest city to national urban population) and density (urban population per square kilometre) measures. As noted by Henderson (2003, p. 50), "primary measures tend to be closely correlated with Hirschman-Herfindahl indices". The HHI has, however, the advantage of considering the entire population of cities rather than only the largest one. Furthermore, with respect to density measures, the HHI accounts for the spatial distribution of population among urban areas (Shen et al., 2019).

3. The control variables referring to the pre-2000 period are defined as average values over different time spans depending on data availability. Given the cross-sectional nature of the analysis, the inclusion of pre-2000 time-averaged control variables allows us to relax business cycle effects that cannot be controlled for using time fixed effects.

4. Online Appendix B reports the full set of results of the OLS and TSLS estimations presented in Table 1, as well as full results concerning the estimations presented in the remainder of the paper.

5. A numerical example of the opposing dynamics characterising employment vs. GDP per capita and labour productivity growth is given by France, i.e., a relatively high-concentrated country characterised by the presence of few very large cities. A comparison with Germany shows that both countries have a similar percentage of urban population (76\% in France, $75 \%$ in Germany), but France has an index of urban concentration 2.5 times larger than Germany. In this example, we consider the long-run growth rate of employment, GDP, GDP per capita, and labour productivity over the period 1984-2014, and focus on the departments where the four French largest cities - Paris, Marseille, Lyon, and Toulouse - are located. The exercise is based on 
Eurostat data (Regio database), with departments corresponding to the level 3 of the Nomenclature des Unités Territoriales Statistiques adopted by the European Union. In France, employment growth increased by $19.38 \%$ at country level, but this increase cannot be attributed to large cities. Indeed, employment growth was slightly higher when considering the average value across all departments, rather than just those where the four largest cities are located (20.46\%). It was lower when considering the average value across the four departments locating the largest cities (14.02\%), and negative when considering Paris only (-6.98\%). In contrast, growth rates of GDP, GDP per capita, and labour productivity were higher in Paris $(85.35 \%, 76.52 \%$, and 99.27\%, respectively) —and, on average, in the departments where the four largest cities are located $(102.91 \%, 69.34 \%$, and $77.97 \%$, respectively) — than in France as a whole $(71.90 \%, 46.91 \%$, and $44.00 \%$, respectively), and in the remaining French departments (65.92\%, 42.24\%, and 37.74\%, respectively). This example corroborates our general empirical results.

6. Online Appendix $\mathrm{C}$ presents several exercises performed to test the robustness of the main results reported in Table 1, that are fully confirmed.

\section{References}

Ahrend R, Lembcke AC and Schumann A (2017) The role of urban agglomerations for economic and productivity growth. International Productivity Monitor 32: 161-179.

Atienza M and Aroca P (2013) Concentration and growth in Latin American countries. In: CuadradoRoura JR and Aroca P (eds) Regional Problems and Policies in Latin America. Berlin: Springer, pp. 113-133.

Barro RJ (1991) Economic growth in a cross section of countries. The Quarterly Journal of Economics 106(2): 407-443.

Berdegué JA, Carriazo F, Jara B, Modrego F and Soloaga I (2015) Cities, territories, and inclusive growth: Unraveling urban-rural linkages in Chile, Colombia, and Mexico. World Development 73: $56-71$.

Bertinelli L and Black D (2004) Urbanization and growth. Journal of Urban Economics 56(1): 8096.

Bertinelli L and Strobl E (2007) Urbanisation, urban concentration and economic development. Urban Studies 44(13): 2499-2510.

Bloom DE, Canning D and Fink G (2008) Urbanization and the wealth of nations. Science 319(5864): $772-775$.

Brülhart M and Sbergami F (2009) Agglomeration and growth: Cross-country evidence. Journal of Urban Economics 65(1): 48-63. 
Castells-Quintana D (2017) Malthus living in a slum: Urban concentration, infrastructure and economic growth. Journal of Urban Economics 98: 158-173.

Ciccone A and Hall R (1996) Productivity and the density of economic activity. American Economic Review 86(1): 54-70.

Dijkstra L, Florczyk A, Freire S, Kemper T and Pesaresi M (2018) Applying the degree of urbanisation to the globe: A new harmonised definition reveals a different picture of global urbanisation. Conference Paper presented at $16^{\text {th }}$ Conference of the International Association of Official Statisticians (IAOS), OECD Headquarters, Paris, France, September 2018.

Duranton G (2015) Growing through cities in developing countries. World Bank Research Observer 30(1): 39-73.

Duranton G and Puga D (2004) Micro-foundations of urban agglomeration economies. In: Henderson JV and Thisse JF (eds) Handbook of Regional and Urban Economics. Burlington: Elsevier, pp. 2064-2117.

Florida RL (2002) The Rise of the Creative Class, and How it is Transforming Work, Leisure, Community and Everyday Life. New York, NY: Basic Books.

Francis J (2009) Agglomeration, job flows and unemployment. The Annals of Regional Science 43: 181-198.

Frick SA and Rodríguez-Pose A (2016) Average city size and economic growth. Cambridge Journal of Regions, Economy and Society 9(2): 301-318.

Frick SA and Rodríguez-Pose A (2018a) Change in urban concentration and economic growth. World Development 105: 156-170.

Frick SA and Rodríguez-Pose A (2018b) Big or small cities? On city size and economic growth. Growth and Change 49(1): 4-32.

Fujita M, Krugman P and Venables AJ (1999) The Spatial Economy: Cities, Regions and International Trade. Cambridge, MA: MIT Press.

Glaeser E, Kallal H, Scheinkman J and Shleifer A (1992) Growth in cities. Journal of Political Economy 100(6): 1126-1152.

Henderson JV (2003) The urbanization process and economic growth: The so-what question. Journal of Economic Growth 8(1): 47-71.

Henderson JV, Kunkoro A and Turner M (1995) Industrial development in cities. Journal of Political Economy 103(5): 1067-1090.

Jacobs J (1969) The Economy of Cities. New York, NY: Vintage.

Krugman P (1991) Geography and Trade. Cambridge, MA: The MIT Press.

Lewis B (2014) Urbanization and economic growth in Indonesia: Good news, bad news and (possible) local government mitigation. Regional Studies 48(1): 192-207. 
Li Y and Liu X (2018) How did urban polycentricity and dispersion affect economic productivity? A case study of 306 Chinese cities. Landscape and Urban Planning 173: 51-59.

Marshall A (1890) Principles of Economics. London: Mcmillan and Co.

Martin P (1999) Public policies, regional inequalities and growth. Journal of Public Economics 73(1): 85-105.

Martin R (2008) National growth versus spatial equality? A cautionary note on the new 'trade-off' thinking in regional policy discourse. Regional Science Policy \& Practice 1(1): 3-13.

Melo PC, Graham DJ and Noland RB (2009) A meta-analysis of estimates of urban agglomeration economies. Regional Science and Urban Economics 39(3): 332-342.

Michaels G, Rauch F and Redding SJ (2012) Urbanization and structural transformation. The Quarterly Journal of Economics 127(2): 535-586.

Motamed MJ, Florax R and Masters WA (2014) Agriculture, transportation and the timing of urbanization: Global analysis at the grid cell level. Journal of Economic Growth 19(3): 339368.

Puga D (2010) The magnitude and causes of agglomeration economies. Journal of Regional Science 50(1): 203-219.

Rodríguez-Pose A and Storper M (2020) Housing, urban growth and inequalities: The limits to deregulation and upzoning in reducing economic and spatial inequality. Urban Studies 57(2): $223-248$.

Rosen KT and Resnick M (1980) The size distribution of cities: An examination of the Pareto law and primacy. Journal of Urban Economics 8(2): 165-186.

Rosenthal S and Strange W (2004) Evidence on the nature and sources of agglomeration economies. In: Henderson JV and Thisse JF (eds) Handbook of Regional and Urban Economics. Burlington: Elsevier, pp. 2119-2171.

Shen J, Chen C, Yang M and Zhang K (2019) City size, population concentration and productivity: Evidence from China. China \& World Economy 27(1): 110-131.

Siebert S, Kummu M, Porkka M, Döll P, Ramankutty N and Scanlon BR (2015) A global data set of the extent of irrigated land from 1900 to 2005. Hydrology and Earth System Science 19(3): $1521-1545$.

United Nations (2019) World Urbanization Prospects: The 2018 Revision. United Nations, Department of Economic and Social Affairs, Population Division, New York, NY.

Veneri P (2018) Urban spatial structure in OECD cities: Is urban population decentralising or clustering? Papers in Regional Science 97(4): 1355-1374.

World Bank (2009) World Development Report 2009. Reshaping Economic Geography. World Bank, Washington, DC. 
Zenou Y (2009) Endogenous job destruction and job matching in cities. Journal of Urban Economics 65(3: 323-336. 
Table 1. The economic returns of urban concentration - All countries.

\begin{tabular}{|c|c|c|c|c|c|c|}
\hline \multirow{2}{*}{$\begin{array}{l}\text { Dependent Variable } \\
\text { Estimation Method }\end{array}$} & \multicolumn{2}{|c|}{ 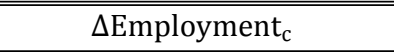 } & \multicolumn{2}{|c|}{ 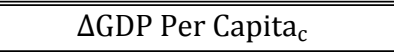 } & \multicolumn{2}{|c|}{$\Delta$ Labour Productivity $_{\mathrm{c}}$} \\
\hline & OLS & TSLS & OLS & TSLS & OLS & TSLS \\
\hline & (1) & (2) & (3) & (4) & (5) & (6) \\
\hline Urban Concentration $_{\mathrm{c}}^{2000}$ & $\begin{array}{l}-0.009 \\
(0.006)\end{array}$ & $\begin{array}{c}-0.030 * * \\
(0.013)\end{array}$ & $\begin{array}{l}0.015^{*} \\
(0.008)\end{array}$ & $\begin{array}{c}0.060 * * * \\
(0.019)\end{array}$ & $\begin{array}{l}0.022 * * \\
(0.009)\end{array}$ & $\begin{array}{c}0.085^{* * * *} \\
(0.020)\end{array}$ \\
\hline $\log \left(\right.$ Employment $\left._{c}^{2000}\right)$ & $\begin{array}{c}-0.003 * * \\
(0.001)\end{array}$ & $\begin{array}{c}-0.006^{* * *} \\
(0.002)\end{array}$ & $\ldots$ & $\ldots$ & $\ldots$ & $\ldots$ \\
\hline $\log \left(\right.$ Labour Productivity $\left.{ }_{c}^{2000}\right)$ & $\ldots$ & $\ldots$ & $\ldots$ & $\ldots$ & $\begin{array}{c}-0.016^{* * * *} \\
(0.003)\end{array}$ & $\begin{array}{c}-0.018^{* * * *} \\
(0.003)\end{array}$ \\
\hline Control Variables & Yes & Yes & Yes & Yes & Yes & Yes \\
\hline Macro-Region Dummies & Yes & Yes & Yes & Yes & Yes & Yes \\
\hline Number of Countries & 108 & 108 & 108 & 108 & 108 & 108 \\
\hline Area Equipped for Irrigation ${ }_{\mathrm{c}}^{1900}$ & $\cdots$ & $\begin{array}{c}0.199^{* * * * *} \\
(0.042)\end{array}$ & $\ldots$ & $\begin{array}{l}0.201^{* * * *} \\
(0.039)\end{array}$ & $\ldots$ & $\begin{array}{l}0.200 * * * * \\
(0.043)\end{array}$ \\
\hline First-Stage F Statistic on Excluded IV [p-value] & $\ldots$ & $22.12[0.000]$ & $\ldots$ & $26.52[0.000]$ & $\ldots$ & $21.47[0.000]$ \\
\hline
\end{tabular}

Notes: $* p<0.1 ; * * p<0.05 ; * * * p<0.01 ; * * * * p<0.001$. Robust standard errors are reported in parentheses. All specifications include a constant term. Table A2 (Online Appendix A) reports the definition of the variables. Tables B1 and B2 (Online Appendix B) report the full set of OLS and TSLS results, respectively. 
Table 2. The economic returns of urban concentration in low- vs. high-income countries.

\begin{tabular}{|c|c|c|c|c|c|c|}
\hline \multirow{2}{*}{$\begin{array}{l}\text { Dependent Variable } \\
\text { Low- vs. High-Income Countries }\end{array}$} & \multicolumn{2}{|c|}{$\Delta$ Employment $_{\mathrm{c}}$} & \multicolumn{2}{|c|}{$\Delta$ GDP Per Capita ${ }_{c}$} & \multicolumn{2}{|c|}{$\Delta$ Labour Productivity $_{\mathrm{c}}$} \\
\hline & Low-Income & High-Income & Low-Income & High-Income & Low-Income & High-Income \\
\hline & $(1)$ & $(2)$ & (3) & $(4)$ & $(5)$ & $(6)$ \\
\hline Urban Concentration $_{\mathrm{c}}^{2000}$ & $\begin{array}{l}-0.029 \\
(0.019)\end{array}$ & $\begin{array}{c}-0.042 * * * \\
(0.015)\end{array}$ & $\begin{array}{l}0.049 * * \\
(0.021)\end{array}$ & $\begin{array}{c}0.080 * * * \\
(0.027)\end{array}$ & $\begin{array}{c}0.077 * * * \\
(0.025)\end{array}$ & $\begin{array}{c}0.108^{* * * * *} \\
(0.032)\end{array}$ \\
\hline $\log \left(\right.$ Employment $\left._{\mathrm{c}}^{2000}\right)$ & $\begin{array}{l}-0.005 \\
(0.004)\end{array}$ & $\begin{array}{c}-0.007 * * * \\
(0.002)\end{array}$ & $\ldots$ & $\ldots$ & $\ldots$ & $\ldots$ \\
\hline $\log \left(\right.$ Labour Productivity $\left.{ }_{c}^{2000}\right)$ & $\cdots$ & $\ldots$ & $\ldots$ & $\ldots$ & $\begin{array}{c}-0.018 * * * * \\
(0.005)\end{array}$ & $\begin{array}{c}-0.019 * * * * \\
(0.004)\end{array}$ \\
\hline Control Variables & Yes & Yes & Yes & Yes & Yes & Yes \\
\hline Macro-Region Dummies & Yes & Yes & Yes & Yes & Yes & Yes \\
\hline Number of Countries & 44 & 64 & 44 & 64 & 44 & 64 \\
\hline First-Stage Estimation & & & & & & \\
\hline Area Equipped for Irrigation ${ }_{c}^{1900}$ & $\begin{array}{l}0.217 * * * * \\
(0.051)\end{array}$ & $\begin{array}{c}0.206^{* * *} \\
(0.065)\end{array}$ & $\begin{array}{l}0.217 * * * * \\
(0.049)\end{array}$ & $\begin{array}{c}0.197 * * * \\
(0.059)\end{array}$ & $\begin{array}{l}0.210^{* * * *} \\
(0.050)\end{array}$ & $\begin{array}{c}0.195 * * * \\
(0.061)\end{array}$ \\
\hline First-Stage F Statistic on Excluded IV [p-value] & $17.96[0.000]$ & $10.07[0.003]$ & $19.36[0.000]$ & $11.21[0.002]$ & $17.37[0.000]$ & $10.31[0.003]$ \\
\hline
\end{tabular}

Notes: $* p<0.1 ; * * p<0.05 ; * * * p<0.01 ; * * * p<0.001$. TSLS estimates. Robust standard errors are reported in parentheses. All specifications include a constant term. The test of equal urban concentration coefficients for low- vs. high-income countries is obtained through bootstrapping (1,000 replications). Table A2 (Online Appendix A) reports the definition of the variables. Table B3 (Online Appendix B) reports the full set of results. 
Table 3. The short- and mid-run economic returns of urban concentration in low-vs. high-income countries.

\begin{tabular}{|c|c|c|c|c|c|c|}
\hline \multirow{3}{*}{$\begin{array}{l}\text { Growth Period of Dependent Variable } \\
\text { Dependent Variable } \\
\text { Low- vs. High-Income Countries } \\
\end{array}$} & \multicolumn{6}{|c|}{$2000-2005$} \\
\hline & \multicolumn{2}{|c|}{$\Delta$ Employment $_{\mathrm{c}}$} & \multicolumn{2}{|c|}{$\Delta$ GDP Per Capita ${ }_{\mathrm{c}}$} & \multicolumn{2}{|c|}{$\Delta$ Labour Productivity $_{c}$} \\
\hline & Low-Income & High-Income & Low-Income & High-Income & Low-Income & High-Income \\
\hline & $(1)$ & $(2)$ & (3) & (4) & $(5)$ & (6) \\
\hline Urban Concentration $_{\mathrm{c}}^{2000}$ & $\begin{array}{c}0.009 \\
(0.021)\end{array}$ & $\begin{array}{l}-0.028 \\
(0.027)\end{array}$ & $\begin{array}{c}0.048 \\
(0.037)\end{array}$ & $\begin{array}{c}0.063 * * \\
(0.026)\end{array}$ & $\begin{array}{c}0.044 \\
(0.040)\end{array}$ & $\begin{array}{l}0.070^{*} \\
(0.038)\end{array}$ \\
\hline $\log \left(\right.$ Employment $\left._{\mathrm{c}}^{2000}\right)$ & $\begin{array}{c}0.000 \\
(0.004)\end{array}$ & $\begin{array}{l}-0.007 \\
(0.004)\end{array}$ & $\ldots$ & $\ldots$ & $\ldots$ & $\ldots$ \\
\hline $\log \left(\right.$ GDP Per Capita $\left.{ }_{c}^{2000}\right)$ & $\ldots$ & $\ldots$ & $\begin{array}{l}-0.014 \\
(0.011)\end{array}$ & $\begin{array}{c}-0.023 * * * * \\
(0.004)\end{array}$ & $\cdots$ & $\ldots$ \\
\hline $\log \left(\right.$ Labour Productivityc $\left.{ }_{c}^{2000}\right)$ & $\cdots$ & $\cdots$ & $\ldots$ & $\ldots$ & $\begin{array}{l}-0.014 \\
(0.009)\end{array}$ & $\begin{array}{c}-0.025^{* * * * *} \\
(0.005)\end{array}$ \\
\hline Control Variables & Yes & Yes & Yes & Yes & Yes & Yes \\
\hline Macro-Region Dummies & Yes & Yes & Yes & Yes & Yes & Yes \\
\hline Number of Countries & 44 & 64 & 44 & 64 & 44 & 64 \\
\hline $\mathrm{R}^{2}$ & 0.47 & 0.56 & 0.57 & 0.74 & 0.53 & 0.71 \\
\hline Model F Statistic [p-value] & $12.55[0.000]$ & $5.51[0.000]$ & $5.78[0.000]$ & $45.55[0.000]$ & $9.11[0.000]$ & $44.31[0.000]$ \\
\hline Equality of Urban Concentration ${ }_{c}^{2000}$ (p-value) & \multicolumn{2}{|c|}{0.093} & \multicolumn{2}{|c|}{0.060} & \multicolumn{2}{|c|}{0.002} \\
\hline \multicolumn{7}{|l|}{ First-Stage Estimation } \\
\hline Area Equipped for Irrigation ${ }_{c}^{1900}$ & $\begin{array}{c}0.217^{* * * *} \\
(0.051)\end{array}$ & $\begin{array}{c}0.206^{* * *} \\
(0.065)\end{array}$ & $\begin{array}{c}0.217^{* * * *} \\
(0.049)\end{array}$ & $\begin{array}{c}0.197 * * * \\
(0.059)\end{array}$ & $\begin{array}{c}0.210 * * * * \\
(0.050)\end{array}$ & $\begin{array}{c}0.195 * * * \\
(0.061)\end{array}$ \\
\hline First-Stage F Statistic on Excluded IV [p-value] & $17.96[0.000]$ & $10.07[0.003]$ & $19.36[0.000]$ & $11.21[0.002]$ & $17.37[0.000]$ & $10.31[0.003]$ \\
\hline Growth Period of Dependent Variable & \multicolumn{6}{|c|}{$2000-2008$} \\
\hline Dependent Variable & \multicolumn{2}{|c|}{$\Delta$ Employment $_{\mathrm{c}}$} & \multicolumn{2}{|c|}{$\Delta$ GDP Per Capita ${ }_{c}$} & \multicolumn{2}{|c|}{$\Delta$ Labour Productivity $_{\mathrm{c}}$} \\
\hline Low- vs. High-Income Countries & Low-Income & High-Income & Low-Income & High-Income & Low-Income & High-Income \\
\hline & $(1)$ & $(2)$ & $(3)$ & $(4)$ & $(5)$ & $(6)$ \\
\hline Urban Concentration $_{\mathrm{c}}^{2000}$ & $\begin{array}{l}-0.019 \\
(0.023)\end{array}$ & $\begin{array}{l}-0.027 \\
(0.018)\end{array}$ & $\begin{array}{c}0.055 \\
(0.039)\end{array}$ & $\begin{array}{l}0.071 * * \\
(0.028)\end{array}$ & $\begin{array}{l}0.081 * \\
(0.043)\end{array}$ & $\begin{array}{l}0.082 * * \\
(0.038)\end{array}$ \\
\hline $\log \left(\right.$ Employment $\left._{c}^{2000}\right)$ & $\begin{array}{l}-0.003 \\
(0.005)\end{array}$ & $\begin{array}{c}-0.005 * * \\
(0.003)\end{array}$ & $\ldots$ & $\cdots$ & $\cdots$ & $\cdots$ \\
\hline $\log \left(\right.$ GDP Per Capita $\left.{ }_{c}^{2000}\right)$ & $\ldots$ & $\cdots$ & $\begin{array}{l}-0.019 * \\
(0.011)\end{array}$ & $\begin{array}{c}-0.025^{* * * * *} \\
(0.004)\end{array}$ & $\cdots$ & $\cdots$ \\
\hline $\log \left(\right.$ Labour Productivity $\left.{ }_{c}^{2000}\right)$ & $\ldots$ & $\cdots$ & $\ldots$ & $\ldots$ & $\begin{array}{c}-0.020 * * \\
(0.010)\end{array}$ & $\begin{array}{c}-0.025^{* * * *} \\
(0.005)\end{array}$ \\
\hline Control Variables & Yes & Yes & Yes & Yes & Yes & Yes \\
\hline Macro-Region Dummies & Yes & Yes & Yes & Yes & Yes & Yes \\
\hline Number of Countries & 44 & 64 & 44 & 64 & 44 & 64 \\
\hline $\mathrm{R}^{2}$ & 0.55 & 0.60 & 0.55 & 0.71 & 0.53 & 0.67 \\
\hline Model F Statistic [p-value] & $5.04[0.000]$ & $6.70[0.000]$ & $6.18[0.000]$ & $59.12[0.000]$ & $15.16[0.000]$ & $112.11[0.000]$ \\
\hline Equality of Urban Concentration ${ }_{c}^{2000}$ (p-value) & \multicolumn{2}{|c|}{0.024} & \multicolumn{2}{|c|}{0.056} & \multicolumn{2}{|c|}{0.011} \\
\hline First-Stage Estimation & & & & & & \\
\hline Area Equipped for Irrigation ${ }_{c}^{1900}$ & $\begin{array}{c}0.217 * * * * \\
(0.051)\end{array}$ & $\begin{array}{c}0.206^{* * *} \\
(0.065)\end{array}$ & $\begin{array}{c}0.217 * * * * \\
(0.049)\end{array}$ & $\begin{array}{c}0.197 * * * \\
(0.059)\end{array}$ & $\begin{array}{c}0.210^{* * * * *} \\
(0.050)\end{array}$ & $\begin{array}{c}0.195 * * * \\
(0.061)\end{array}$ \\
\hline First-Stage F Statistic on Excluded IV [p-value] & $17.96[0.000]$ & $10.07[0.003]$ & $19.36[0.000]$ & $11.21[0.002]$ & $17.37[0.000]$ & $10.31[0.003]$ \\
\hline
\end{tabular}

Notes: $* p<0.1 ; * * p<0.05 ; * * * p<0.01 ; * * * * p<0.001$. TSLS estimates. Robust standard errors are reported in parentheses. All specifications include a constant term. The test of equal urban concentration coefficients for low- vs. high-income countries is obtained through bootstrapping (1,000 replications). Table A2 (Online Appendix A) reports the definition of the variables. Tables B4 and B5 (Online Appendix B) report the full set of results for the short- and mid-run periods, respectively. 
Table 4. The economic returns of urban concentration for low- vs. high-density urban areas within FUAs.

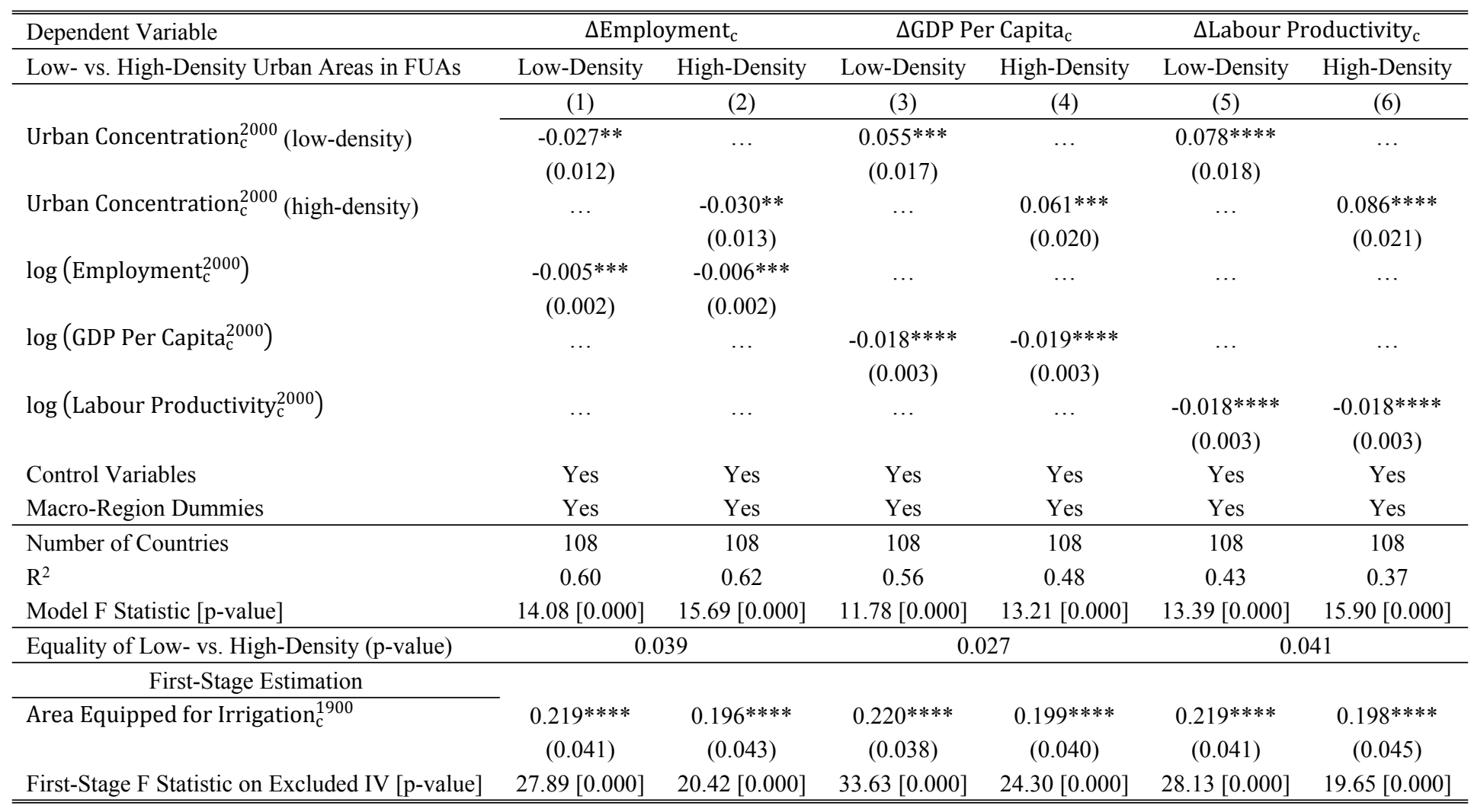

Notes: $* p<0.1 ; * * p<0.05 ; * * * p<0.01 ; * * * p<0.001$. TSLS estimates. Robust standard errors are reported in parentheses. All specifications include a constant term. The test of equality between low- vs. high-density urban concentration coefficients is obtained through bootstrapping (1,000 replications). Table A2 (Online Appendix A) reports the definition of the variables. Table B6 (Online Appendix B) reports the full set of results. 
Table 5. The economic returns of urban concentration by FUAs' population threshold values.

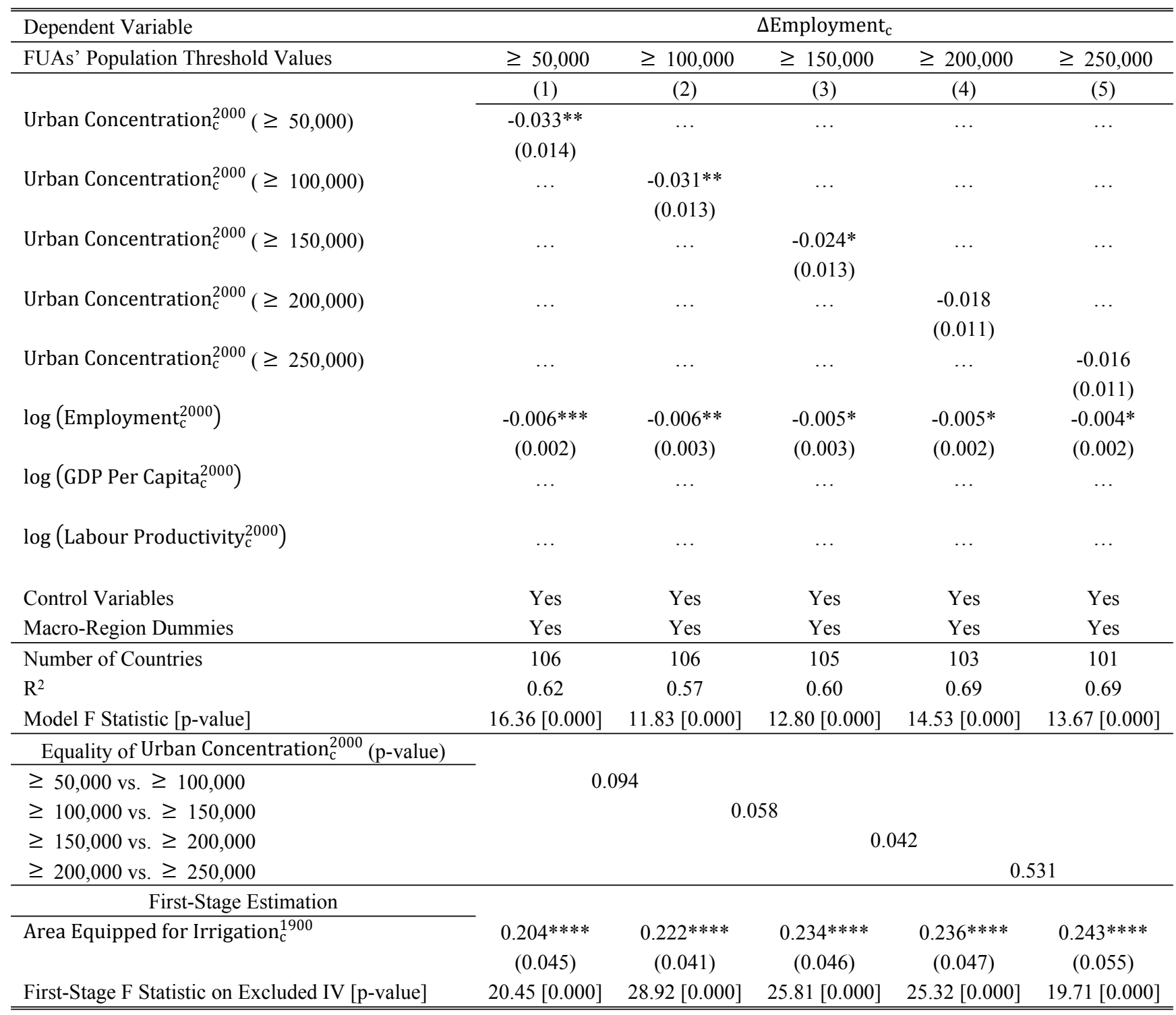

Notes: $* p<0.1 ; * * p<0.05 ; * * * p<0.01 ; * * * * p<0.001$. TSLS estimates. Robust standard errors are reported in parentheses. All specifications include a constant term. Threshold values are defined in terms of (urban and rural) population residing within a FUA. The test of equality between pairs of urban concentration coefficients is obtained through bootstrapping (1,000 replications). Table A2 (Online Appendix A) reports the definition of the variables. Table B7 (Online Appendix B) reports the full set of results. 
Table 5 - Continued.

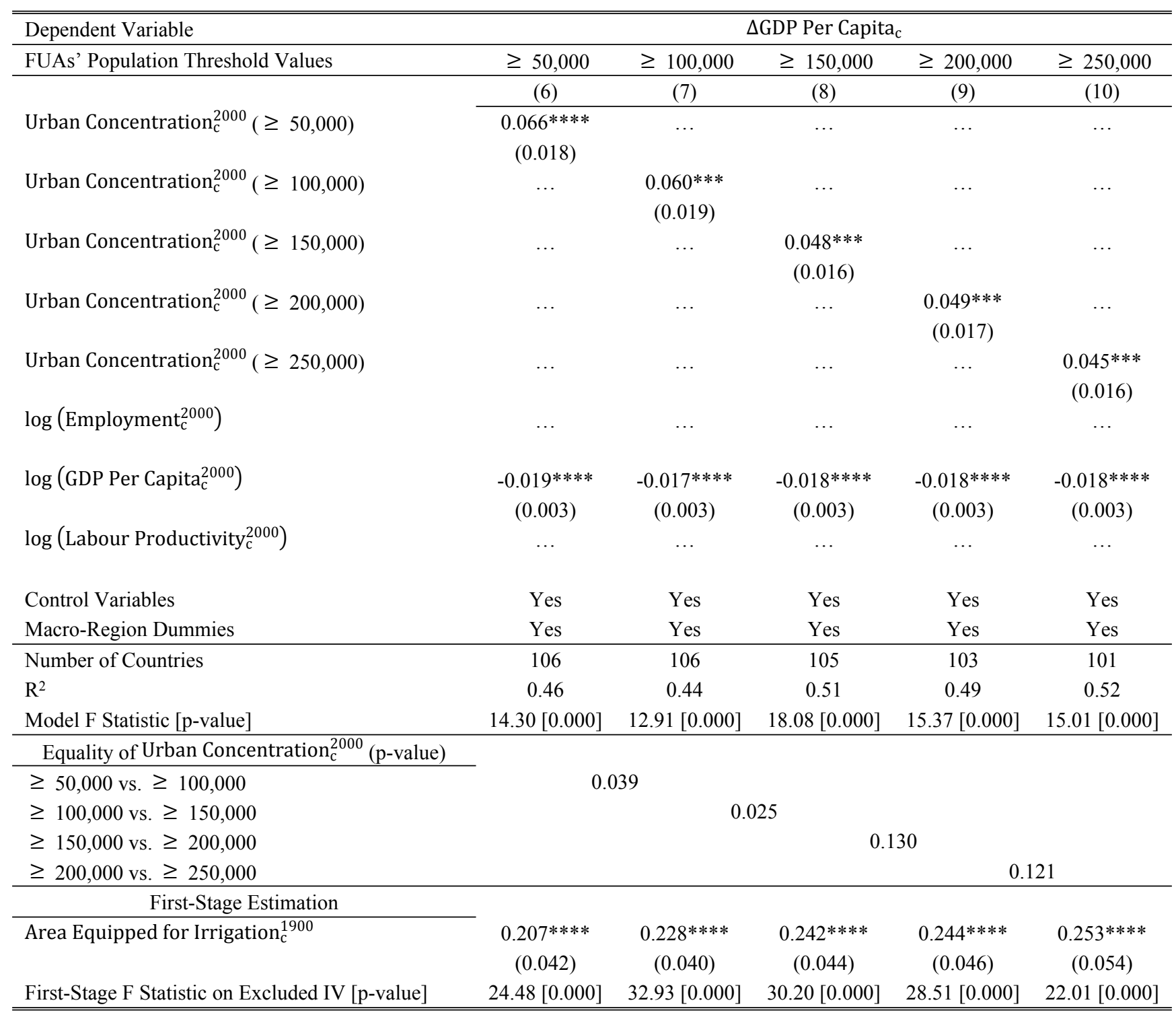

Notes: $* p<0.1 ; * * p<0.05 ; * * * p<0.01 ; * * * p<0.001$. TSLS estimates. Robust standard errors are reported in parentheses. All specifications include a constant term. Threshold values are defined in terms of (urban and rural) population residing within a FUA. The test of equality between pairs of urban concentration coefficients is obtained through bootstrapping (1,000 replications). Table A2 (Online Appendix A) reports the definition of the variables. Table B7 (Online Appendix B) reports the full set of results. 
Table 5 - Continued.

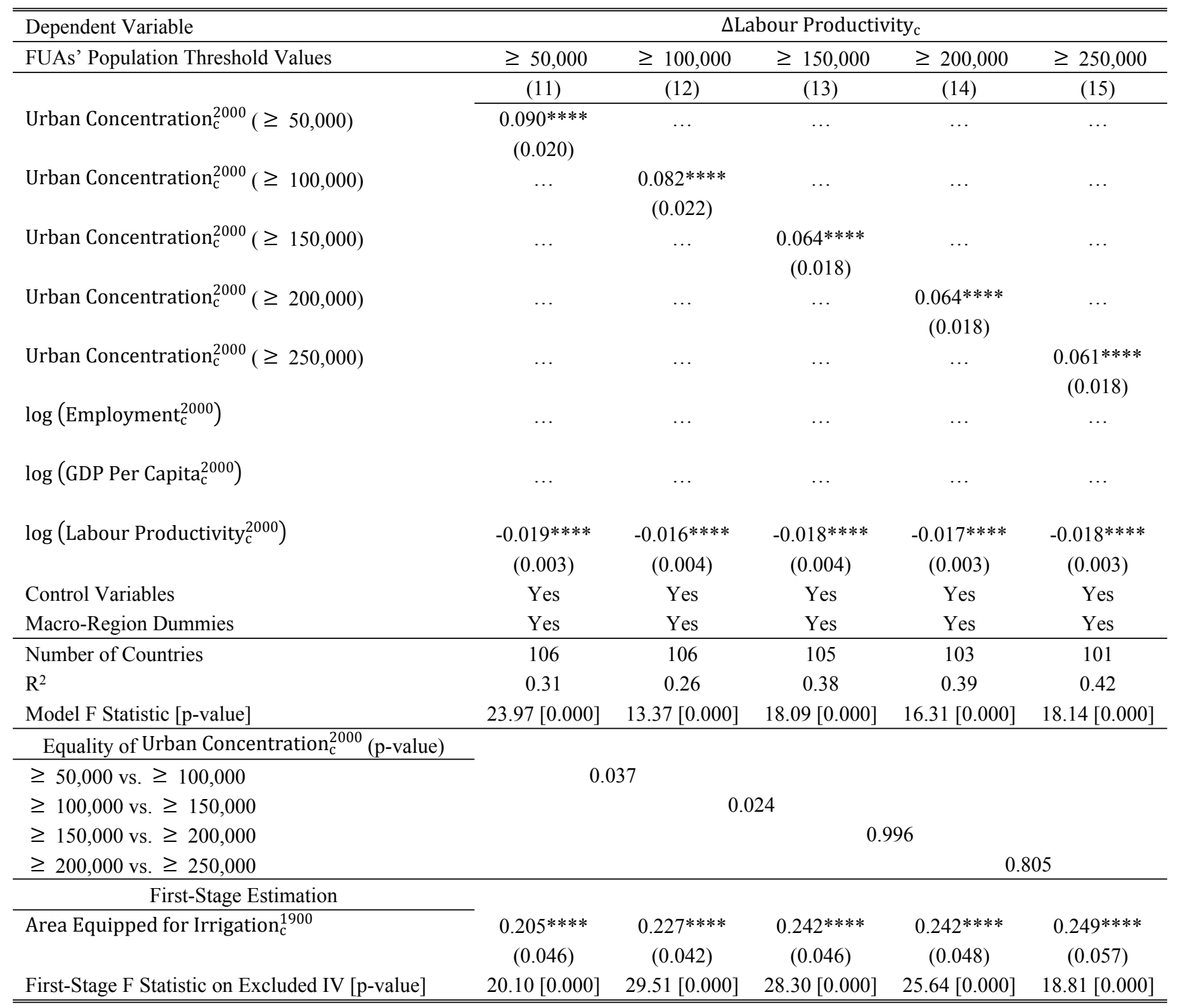

Notes: $* p<0.1 ; * * p<0.05 ; * * * p<0.01 ; * * * * p<0.001$. TSLS estimates. Robust standard errors are reported in parentheses. All specifications include a constant term. Threshold values are defined in terms of (urban and rural) population residing within a FUA. The test of equality between pairs of urban concentration coefficients is obtained through bootstrapping (1,000 replications). Table A2 (Online Appendix A) reports the definition of the variables. Table B7 (Online Appendix B) reports the full set of results. 


\section{ONLINE APPENDICES}

\section{ONLINE APPENDIX A - Sample, data, and descriptive statistics}

The sample used in the empirical analysis consists of 108 low- and high-income countries, defined according to the taxonomy adopted by the World Bank Group (WBG). Countries in the sample have been selected starting from the 190 States included in the Global Human Settlement Layer (GHSL) database. This database, developed by the Joint Research Centre and the Directorate-General for Regional and Urban Policy (DG REGIO) of the European Commission, provides detailed information on population residing in urban areas defined in terms of Functional Urban Areas (FUA), i.e., adopting a 'functional' rather than an administrative and city-level definition of the urban space. The GHSL database provides gridded population data reconstructed from national censuses. It represents one of the most accurate population databases available, in particular given its detailed information on internal characteristics of FUAs, i.e., the identification of high-density urban, low-density suburban, and rural areas within FUAs.

However, despite its detailed information, it comes with some limitations. First, the Landsat remote sensing process used to collect fine-level geographic data does not present the same degree of accuracy in all macro-regions around the world, such that automated retrieving process of urban settlements tends to under- or over-estimate urban population in some macro-regions. Second, there are some differences between the GHSL database and its analogue developed by the Organisation for Economic Co-operation and Development (OECD), such that some FUAs are not identified in either one or both databases, or do not perfectly match. Finally, there are cases in which built contiguity surpasses a FUA's boundaries. ${ }^{1}$

\footnotetext{
${ }^{1}$ The population data defined at the FUA level used in the empirical analysis have been provided by the DG REGIO in a shapefile format, with FUAs defined according to the methodology adopted by the European Union and the OECD. Dijkstra et al. (2018) provide a description of the database and of its characteristics and compare it with the widely-used World Urbanization Prospects (WUP) database provided by the United Nations (UN). For further details, visit also the website "https://ghsl.jrc.ec.europa.eu/".
} 
In any case, the key advantage of the GHSL database is that of employing a globallyharmonised definition of FUAs that allows for a direct comparison of the degree of urban concentration among countries worldwide. This makes the GHSL database more suitable for the purposes of the paper with respect to other databases usually employed in the analysis of countrylevel urban concentration - such as, for example, the WUP database developed by the UN - that use the city as the spatial unit of analysis. In these databases, cities are measured following diverse national definitions. In addition, the FUA definition of the 'urban space' has the advantage of capturing the physical and functional space where socio-economic activities take place, while the administrative-based concept of 'city' does not necessarily encompass these dimensions (Ahrend et al., 2017; Dijkstra et al., 2018).

Subsequently, a cleaning procedure has been applied to remove city-states (e.g., Kuwait, Luxembourg, Singapore) and autonomous territories (e.g., Hong Kong, Macao) due to their peculiar and extremely concentrated urban structure. The sample has also been cleaned to consider only countries for which the economic and demographic data series needed to construct the dependent and control variables were available. Specifically, economic and demographic data were drawn from four main source: the World Development Indicators database (WBG), the World Governance Indicators database (WBG), the Penn World Table (Feenstra et al., 2015), and the Barro and Lee Dataset. These are data sources usually employed in cross-country economic growth analyses. Cross-country data comparability is guaranteed by the fact that data are globally harmonised although they are drawn from different national statistical sources.

Table A1 provides the list of countries included in the sample by macro-region (Africa, Asia, Europe, Latin America and the Caribbean, North America, and Oceania) defined according to the taxonomy adopted by the UN. Table A2 reports the definition and data source of each variable employed in the empirical analysis. Tables A3 and A4 present some descriptive statistics relating to the dependent and explanatory variables, and the correlation matrix of the explanatory variables, respectively. 
Figures A1 to A3 map the spatial distribution of the dependent variables for employment, GDP per capita, and labour productivity growth over the period 2000-2016, while Figures A4 and A5 map the spatial distribution of urban concentration by country and its variability within macro-region, respectively. Finally, Figure A6 maps the spatial distribution of low- and high-income countries included in the sample. 
Table A1: Countries in the sample.

\begin{tabular}{cc}
\hline \hline Macro-Region & Africa \\
\hline Countries & $\begin{array}{c}\text { Algeria, Benin, Botswana, Burundi, Cameroon, Central African Republic, Côte d'Ivoire, Egypt, Gabon, } \\
\text { Gambia, Ghana, Kenya, Malawi, Mali, Morocco, Mozambique, Namibia, Niger, Republic of Congo, Rwanda, } \\
\text { Senegal, Sierra Leone, South Africa, Swaziland, Tunisia, Uganda, Zimbabwe }\end{array}$ \\
\hline Macro-Region & Asia \\
\hline Countries & $\begin{array}{c}\text { Armenia, Bahrain, Bangladesh, Brunei, Cambodia, China, Cyprus, India, Indonesia, Iran, Israel, Japan, Jordan, } \\
\text { Kazakhstan, Kyrgyzstan, Malaysia, Mongolia, Nepal, Pakistan, Philippines, Saudi Arabia, South Korea, Sri } \\
\text { Lanka, Tajikistan, Thailand, Turkey, Vietnam }\end{array}$
\end{tabular}

\begin{tabular}{cc}
\hline Macro-Region & Europe \\
\hline \multirow{2}{*}{ Countries } & Albania, Austria, Belgium, Bulgaria, Croatia, Czech Republic, Denmark, Estonia, Finland, France, Germany, \\
& $\begin{array}{l}\text { Greece, Hungary, Ireland, Italy, Latvia, Lithuania, Moldova, Netherlands, Norway, Poland, Portugal, } \\
\text { Romania, Russia, Slovak Republic, Slovenia, Spain, Sweden, Switzerland, Ukraine, United Kingdom }\end{array}$
\end{tabular}

\begin{tabular}{cc}
\hline Macro-Region & Latin America and the Caribbean \\
\hline Countries & Argentina, Barbados, Belize, Bolivia, Brazil, Chile, Colombia, Costa Rica, Dominican Republic, Ecuador, El \\
Salvador, Guatemala, Honduras, Jamaica, Mexico, Nicaragua, Panama, Paraguay, Peru
\end{tabular}

\begin{tabular}{ll}
\hline Macro-Region & North America \\
\hline
\end{tabular}

Countries Canada, United States of America

\begin{tabular}{ll}
\hline Macro-Region & Oceania \\
\hline Countries
\end{tabular}

Countries

Australia, New Zealand \begin{tabular}{l}
\hline Notes: Countries are classified by macro-region according to the taxonomy adopted by the United Nations. China does not include \\
the autonomous regions of Hong Kong and Macao.
\end{tabular} 
Table A2: Definition and data source of variables.

\begin{tabular}{|c|c|c|}
\hline Variable & Definition & Data Source \\
\hline$\Delta$ Employment $_{\mathrm{c}}$ & Average yearly growth rate of total employment between 2000 and 2016 & World Development Indicators (World Bank Group) \\
\hline$\Delta$ GDP Per Capita & Average yearly growth rate of total GDP-to-population ratio between 2000 and 2016 & World Development Indicators (World Bank Group) \\
\hline$\Delta$ Labour Productivity $_{\mathrm{c}}$ & Average yearly growth rate of total GDP-to-total employment ratio between 2000 and 2016 & World Development Indicators (World Bank Group) \\
\hline Urban Concentration $_{c}^{2000}$ & $\begin{array}{l}\text { Herfindahl-Hirschman Index defined on urban population within FUAs (i.e., people residing } \\
\text { in high-density urban core and low-density suburban areas) }\end{array}$ & Global Human Settlement Layer (European Commission) \\
\hline $\log \left(\right.$ Employment $\left.{ }_{c}^{2000}\right)$ & Total employment in 2000 & World Development Indicators (World Bank Group) \\
\hline $\log \left(\right.$ Employment $t_{c}^{\text {Avg. } 1991 \text { to } 2000)}$ & Average value (period 1991-2000) of total employment & World Development Indicators (World Bank Group) \\
\hline $\log ($ GDP Per Capita 2000$)$ & Total GDP-to-population ratio in 2000 & World Development Indicators (World Bank Group) \\
\hline $\log \left(\right.$ GDP Per Capita ${ }_{c}^{\text {Avg. }} 1990$ to 2000$)$ & Average value (period 1990-2000) of total GDP-to-population ratio & World Development Indicators (World Bank Group) \\
\hline $\log \left(\right.$ Labour Productivity $\left.{ }_{c}^{2000}\right)$ & Total GDP-to-total employment ratio in 2000 & World Development Indicators (World Bank Group) \\
\hline Gross Fixed Capital Formation to GDP Avg. 1990 to 2000 & Average value (period 1990-2000) of gross fixed capital formation as percentage of total GDP & World Development Indicators (World Bank Group) \\
\hline Share of Government Consumption ${ }_{c}^{\text {Avg. }} 1990$ to 2000 & Average value (period 1990-2000) of the share of government consumptions & Penn World Table V. 9.0 (Feenstra et al., 2015) \\
\hline Oil Rent to GDP Avg. 1990 to 2000 & Average value (period 1990-2000) of oil rents as percentage of total GDP & World Development Indicators (World Bank Group) \\
\hline 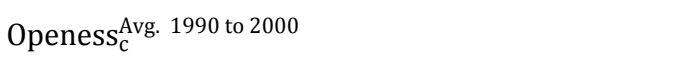 & Average value (period 1990-2000) of export-to-GDP plus import-to-GDP ratios & World Development Indicators (World Bank Group) \\
\hline Share of High Tech Export ${ }_{c}^{\text {Avg. }} 1990$ to 2000 & $\begin{array}{l}\text { Average value (period 1990-2000) of the share of high-tech manufacturing exports to total } \\
\text { manufacturing exports }\end{array}$ & World Development Indicators (World Bank Group) \\
\hline High Income $_{c}(\mathrm{~d})$ & Dummy variable taking value one for high-income countries; zero otherwise & World Bank Group \\
\hline Population Density Avg. 1990 to 2000 & Average value (period 1900-2000) of total population per square kilometre & World Development Indicators (World Bank Group) \\
\hline Years of Schooling Avg. 1990, 1995, 2000 & Average value (years $1990,1995,2000$ ) of the absolute number of years of schooling & Barro and Lee Dataset V. 2.2 (http://www.barrolee.com) \\
\hline
\end{tabular}




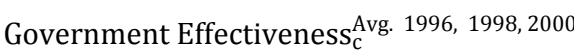

$\log \left(\right.$ Surface $\left._{c}\right)$

Island $_{c}(\mathrm{~d})$

Landlocked $_{c}(\mathrm{~d})$

Latitude $_{c}$

Longitude $_{c}$

Area Equipped for Irrigation $_{\mathrm{c}}^{1900}$

Terrain Ruggedness

Share Urban Land ${ }_{c}^{1881}$

Percentage Urban Population ${ }_{\mathrm{c}}^{\text {Avg. }} 1990$ to 2000

$\log \left(\right.$ GDP Per Capita $\left.{ }_{c}^{1900}\right)$
Average value (years 1996, 1998, 2000) of a synthetic index capturing perceptions of quality of public services, quality of the civil service and degree of its independence from political pressures, quality of policy formulation and implementation, and credibility of the government's commitment to such policies

\section{Land surface (square kilometre)}

Dummy variable taking value one for insular countries; zero otherwise

Dummy variable taking value one for landlocked countries; zero otherwise

Latitude value of geographic centroid of a country

Longitude value of geographic centroid of a country

Share of land area equipped for irrigation over total land area in 1900

Terrain ruggedness index as calculated by Nunn and Puga (2012)

Share of land defined as 'urban' over total land area in 1881

Average value (period 1990-2000) of urban population-to-total population

Total GDP-to-population ratio in 1900
Worldwide Governance Indicators (World Bank Group)

World Development Indicators (World Bank Group)

Authors' Elaboration

Centre d'Etudes Prospectives et d'Informations Internationales

Centre d'Etudes Prospectives et d'Informations Internationales

Centre d'Etudes Prospectives et d'Informations Internationales

Historical Irrigation Dataset (Siebert et al. 2015)

Nunn and Puga (2012)

Historical Database of the Global Environment HYDE V. 3.1

(Goldewijk et al. 2010; Goldewijk et al. 2011)

World Development Indicators (World Bank Group)

Geiger and Frieler (2018)

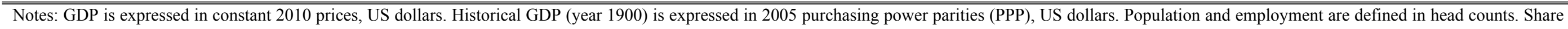
of government consumptions is defined in constant PPPs. Oil rents are the difference between the value of crude oil production at regional prices and total costs of production. 
Table A3: Descriptive statistics of the dependent and the explanatory variables.

\begin{tabular}{|c|c|c|c|c|}
\hline & Mean & Std. Dev. & Min. & Max. \\
\hline \multicolumn{5}{|l|}{ Dependent Variables } \\
\hline$\Delta$ Employment $_{\mathrm{c}}$ & 0.018 & 0.014 & -0.016 & 0.064 \\
\hline$\Delta$ GDP Per Capita ${ }_{c}$ & 0.023 & 0.018 & -0.018 & 0.085 \\
\hline$\Delta$ Labour Productivity $_{\mathrm{c}}$ & 0.017 & 0.018 & -0.027 & 0.086 \\
\hline \multicolumn{5}{|l|}{ Explanatory Variables } \\
\hline Urban Concentration $_{\mathrm{c}}^{2000}$ & 0.319 & 0.255 & 0.005 & 1.000 \\
\hline $\log \left(\right.$ Employment $\left._{\mathrm{c}}^{2000}\right)$ & 15.352 & 1.618 & 11.285 & 20.369 \\
\hline $\log \left(\right.$ Employment ${ }_{c}^{\text {Avg. } 1991 \text { to 2000 })}$ & 15.272 & 1.628 & 11.091 & 20.310 \\
\hline $\log \left(\right.$ GDP Per Capita $\left.{ }_{c}^{2000}\right)$ & 8.413 & 1.565 & 5.431 & 11.311 \\
\hline $\log \left(\right.$ GDP Per Capita ${ }_{c}^{\text {Avg. }} 1990$ to 2000$)$ & 8.335 & 1.534 & 5.309 & 11.169 \\
\hline $\log \left(\right.$ Labour Productivity $\left.{ }_{c}^{2000}\right)$ & 9.375 & 1.502 & 6.306 & 11.970 \\
\hline Gross Fixed Capital Formation to GDP $P_{\mathrm{c}}^{\text {Avg. }} 1990$ to 2000 & 0.212 & 0.054 & 0.063 & 0.357 \\
\hline 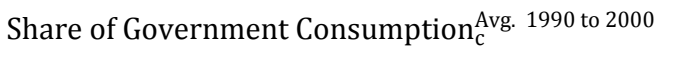 & 0.194 & 0.086 & 0.074 & 0.544 \\
\hline Oil Rent to GDP Avg. 1990 to 2000 & 0.020 & 0.058 & 0.000 & 0.373 \\
\hline Openess $\mathrm{C}_{\mathrm{c}}^{\text {Avg. } 1990 \text { to } 2000}$ & 0.704 & 0.325 & 0.181 & 1.820 \\
\hline Share of High Tech Export ${ }_{c}^{\text {Avg. }} 1990$ to 2000 & 0.093 & 0.106 & 0.000 & 0.501 \\
\hline $\operatorname{High~Income~}_{\mathrm{c}}(\mathrm{d})$ & 0.593 & 0.494 & 0 & 1 \\
\hline Population DensityAvg. 1990 to 2000 & $1,127.551$ & $1,492.216$ & 14.664 & $9,127.264$ \\
\hline Years of Schooling ${ }_{c}^{\text {Avg. }}$ 1990, 1995, 2000 & 7.219 & 2.824 & 1.003 & 12.477 \\
\hline 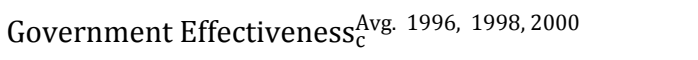 & 0.187 & 0.938 & -1.543 & 2.031 \\
\hline $\log \left(\right.$ Surface $\left._{c}\right)$ & 12.247 & 1.877 & 6.064 & 16.612 \\
\hline $\operatorname{Island}_{c}(\mathrm{~d})$ & 0.120 & 0.327 & 0 & 1 \\
\hline Landlocked $_{c}(\mathrm{~d})$ & 0.213 & 0.411 & 0 & 1 \\
\hline Latitude $_{c}$ & 22.501 & 26.047 & -41.806 & 64.481 \\
\hline Longitude $_{c}$ & 16.268 & 60.599 & -112.982 & 171.478 \\
\hline
\end{tabular}

Notes: Statistics refer to the 108 countries in the sample. (d) denotes a binary variable. Table A2 (Online Appendix A) reports the definition of the variables. 
Table A4: Correlation matrix of the explanatory variables.

\begin{tabular}{|c|c|c|c|c|c|c|c|c|c|c|c|c|c|c|c|c|c|c|c|c|c|}
\hline & & [1] & [2] & [3] & [4] & [5] & [6] & [7] & [8] & [9] & [10] & [11] & [12] & [13] & [14] & [15] & [16] & [17] & [18] & [19] & [20] \\
\hline Urban Concentration $_{\mathrm{c}}^{2000}$ & [1] & 1 & & & & & & & & & & & & & & & & & & & \\
\hline $\log \left(\right.$ Employment $\left._{c}^{2000}\right)$ & {$[2]$} & -0.8 & 1 & & & & & & & & & & & & & & & & & & \\
\hline $\log \left(\right.$ Employment ${ }_{c}^{\text {Avg. } 1991 \text { to } 2000)}$ & {$[3]$} & -0.8 & 1.0 & 1 & & & & & & & & & & & & & & & & & \\
\hline $\log \left(\right.$ GDP Per Capitac $\left.{ }_{c}^{2000}\right)$ & {$[4]$} & 0.1 & 0.0 & 0.0 & 1 & & & & & & & & & & & & & & & & \\
\hline $\log ($ GDP Per Capita Avg. 1990 to 2000) & {$[5]$} & 0.1 & 0.0 & 0.0 & 1.0 & 1 & & & & & & & & & & & & & & & \\
\hline $\log \left(\right.$ Labour Productivity $\left._{c}^{2000}\right)$ & {$[6]$} & 0.1 & 0.0 & 0.0 & 1.0 & 1.0 & 1 & & & & & & & & & & & & & & \\
\hline Gross Fixed Capital Formation to GDP Cvg. $^{\text {Avg }} 1990$ to 2000 & [7] & -0.1 & 0.2 & 0.2 & 0.4 & 0.4 & 0.4 & 1 & & & & & & & & & & & & & \\
\hline Share of Government Consumption $\mathrm{c}_{\mathrm{c}}^{\text {Avg. }} 1990$ to 2000 & {$[8]$} & 0.2 & -0.2 & -0.2 & -0.1 & -0.1 & -0.1 & 0.1 & 1 & & & & & & & & & & & & \\
\hline Oil Rent to GDP ${ }_{c}^{\text {Avg. }} 1990$ to 2000 & [9] & 0.0 & -0.1 & -0.1 & 0.1 & 0.1 & 0.1 & 0.2 & 0.1 & 1 & & & & & & & & & & & \\
\hline 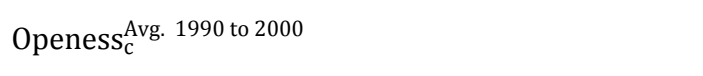 & {$[10]$} & 0.5 & -0.6 & -0.6 & 0.1 & 0.1 & 0.2 & 0.2 & 0.3 & 0.1 & 1 & & & & & & & & & & \\
\hline Share of High Tech Export $\mathrm{c}_{\mathrm{c}}^{\text {Avg. }} 1990$ to 2000 & {$[11]$} & 0.0 & 0.1 & 0.1 & 0.3 & 0.3 & 0.3 & 0.2 & 0.0 & 0.0 & 0.2 & 1 & & & & & & & & & \\
\hline High Income $_{c}(d)$ & {$[12]$} & 0.0 & 0.0 & 0.0 & 0.8 & 0.8 & 0.8 & 0.4 & -0.1 & 0.1 & 0.0 & 0.2 & 1 & & & & & & & & \\
\hline Population Density Avg. 1990 to 2000 & {$[13]$} & 0.1 & 0.1 & 0.1 & 0.1 & 0.1 & 0.0 & 0.0 & -0.1 & -0.2 & 0.0 & 0.1 & -0.1 & 1 & & & & & & & \\
\hline Years of Schooling Avg. 1990, 1995, 2000 & {$[14]$} & 0.1 & 0.0 & 0.0 & 0.8 & 0.8 & 0.7 & 0.4 & 0.3 & -0.1 & 0.3 & 0.3 & 0.7 & 0.0 & 1 & & & & & & \\
\hline 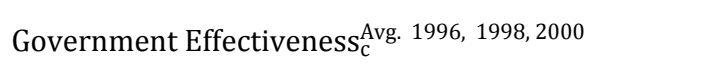 & {$[15]$} & 0.1 & 0.0 & 0.0 & 0.9 & 0.9 & 0.8 & 0.4 & -0.2 & -0.2 & 0.1 & 0.3 & 0.6 & 0.1 & 0.7 & 1 & & & & & \\
\hline $\log \left(\right.$ Surface $\left._{c}\right)$ & {$[16]$} & -0.6 & 0.7 & 0.7 & -0.1 & -0.1 & -0.1 & 0.1 & -0.1 & 0.2 & -0.5 & 0.0 & 0.1 & -0.5 & -0.1 & -0.1 & 1 & & & & \\
\hline Island $_{c}(\mathrm{~d})$ & {$[17]$} & 0.3 & -0.1 & -0.1 & 0.2 & 0.2 & 0.2 & 0.1 & -0.1 & 0.0 & 0.2 & 0.2 & 0.1 & 0.3 & 0.2 & 0.2 & -0.3 & 1 & & & \\
\hline Landlocked $_{c}(\mathrm{~d})$ & {$[18]$} & 0.1 & -0.2 & -0.2 & -0.3 & -0.3 & -0.3 & -0.2 & 0.3 & -0.1 & 0.1 & -0.1 & -0.3 & -0.1 & -0.1 & -0.3 & 0.0 & -0.2 & 1 & & \\
\hline
\end{tabular}




\begin{tabular}{|c|c|c|c|c|c|c|c|c|c|c|c|c|c|c|c|c|c|c|c|c|c|}
\hline Latitude $_{c}$ & [19] & -0.1 & 0.1 & 0.1 & 0.4 & 0.4 & 0.4 & 0.2 & 0.3 & -0.1 & 0.1 & 0.2 & 0.3 & 0.1 & 0.4 & 0.4 & -0.1 & -0.1 & -0.1 & 1 & \\
\hline Longitude $_{c}$ & {$[20]$} & -0.1 & 0.2 & 0.2 & -0.1 & -0.1 & -0.1 & 0.3 & 0.2 & 0.1 & 0.1 & 0.1 & -0.1 & 0.2 & 0.0 & 0.0 & 0.1 & 0.2 & 0.1 & 0.1 & 1 \\
\hline
\end{tabular}

Notes: Correlation coefficients refer to the 108 countries in the sample. (d) denotes a binary variable. Table A2 (Online Appendix A) reports the definition of the variables. 
Figure A1: Spatial distribution of employment growth over the period 2000-2016.

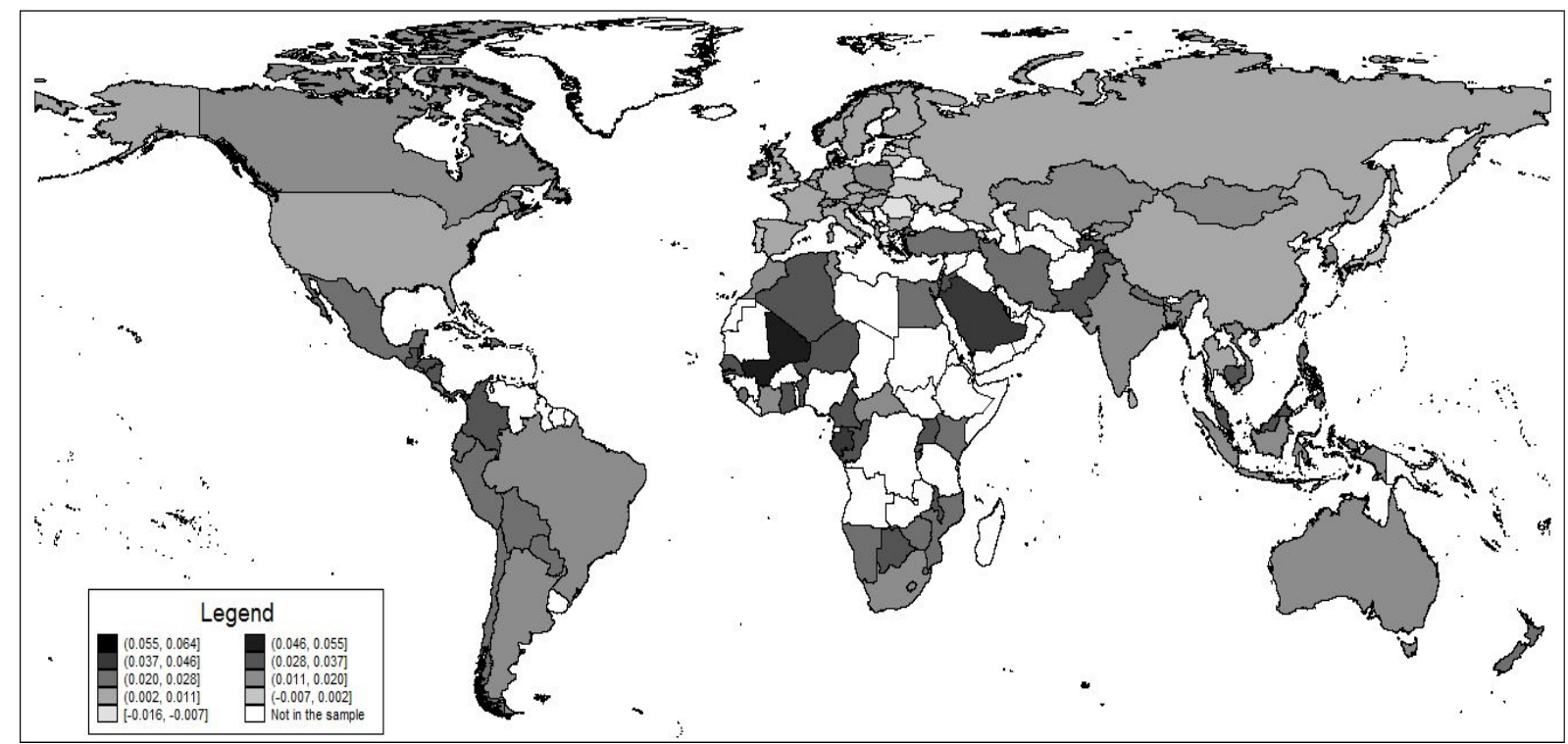

Notes: The map considers the dependent variable for employment growth entering Equation (1), and defined as average yearly growth rate between the years 2000 and 2016. Darker shades refer to higher values of the mapped variable. 
Figure A2: Spatial distribution of GDP per capita growth over the period 2000-2016.

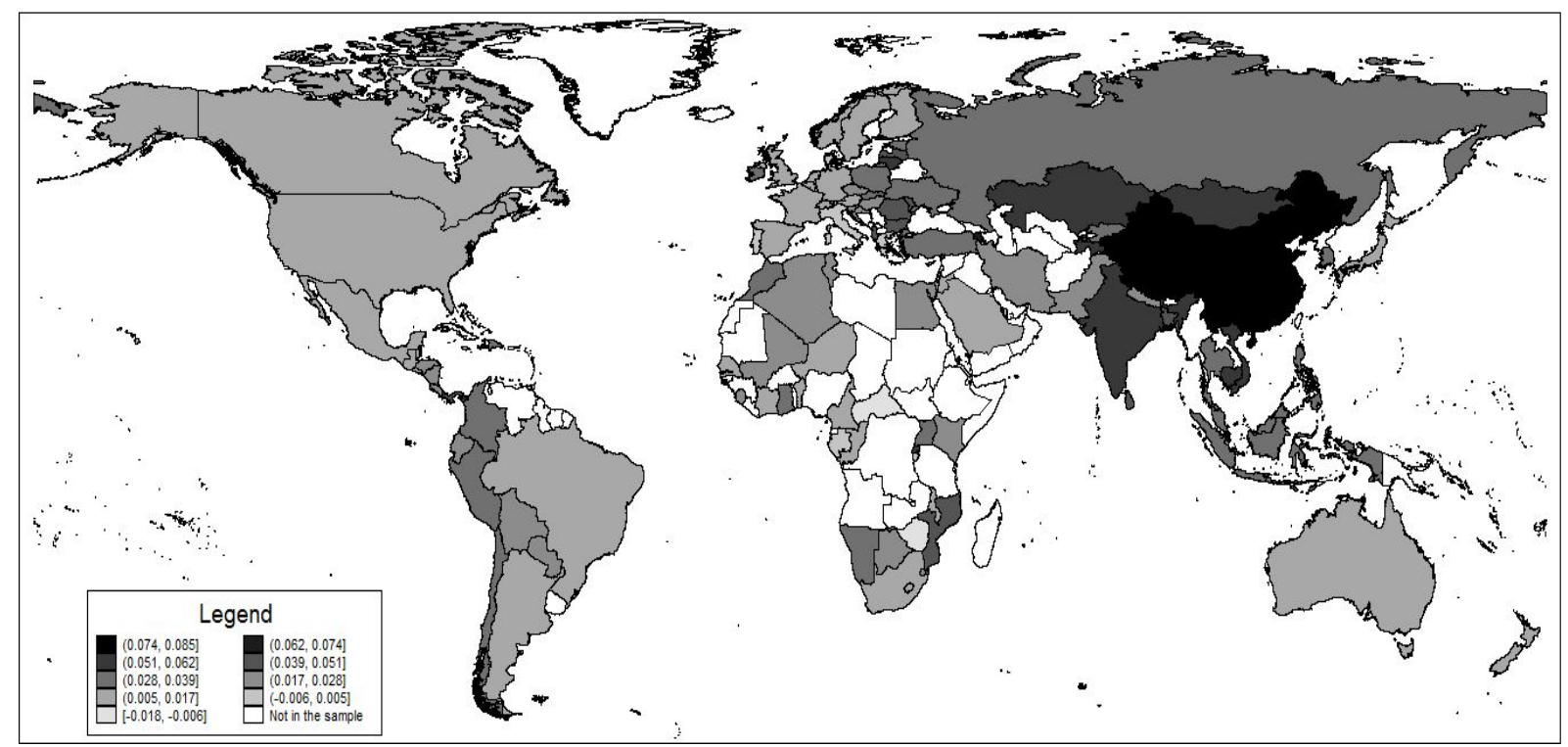

Notes: The map considers the dependent variable for GDP per capita growth entering Equation (1), and defined as average yearly growth rate between the years 2000 and 2016. Darker shades refer to higher values of the mapped variable. 
Figure A3: Spatial distribution of labour productivity growth over the period 2000-2016.

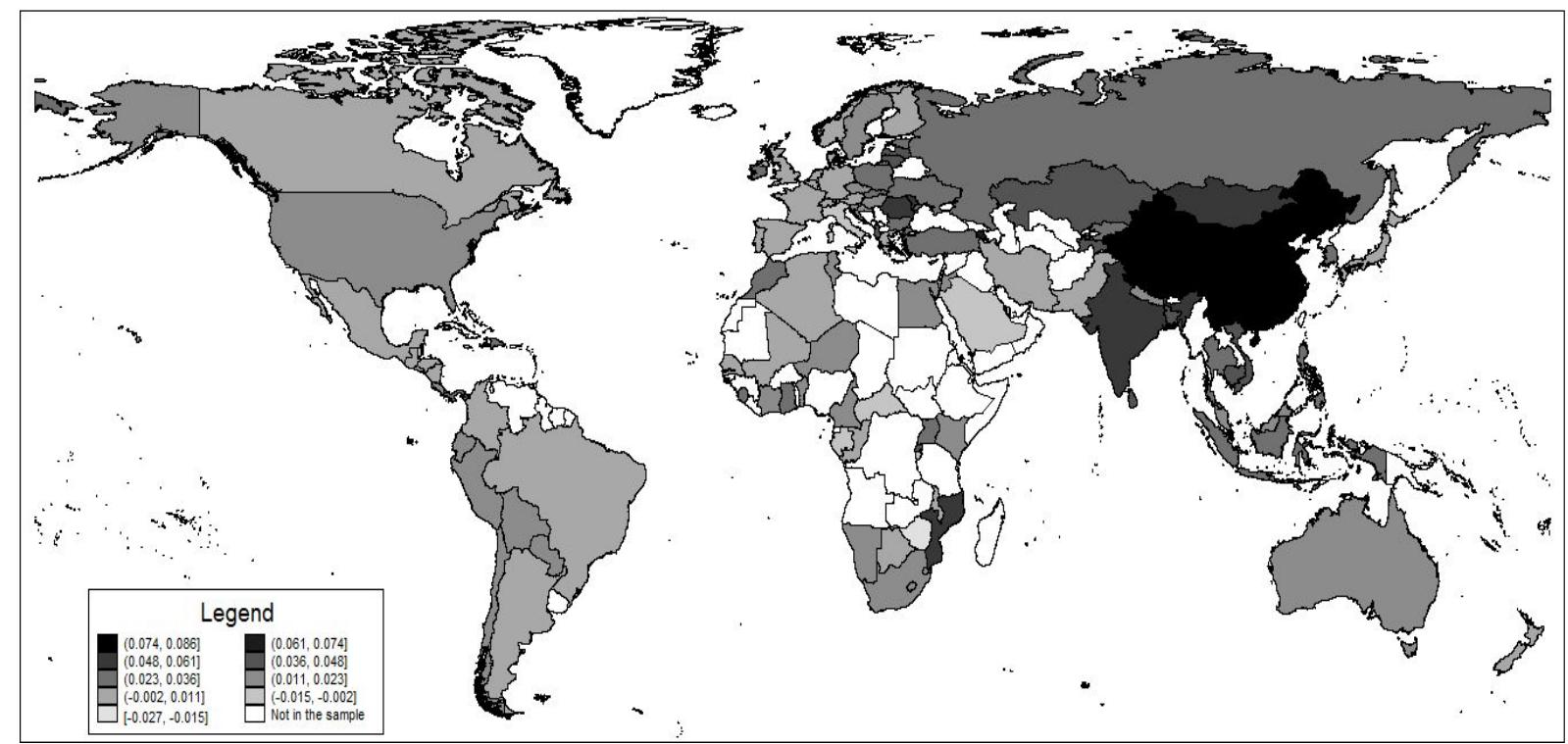

Notes: The map considers the dependent variable for labour productivity growth entering Equation (1), and defined as average yearly growth rate between the years 2000 and 2016. Darker shades refer to higher values of the mapped variable. 
Figure A4: Spatial distribution of urban concentration in the year 2000.

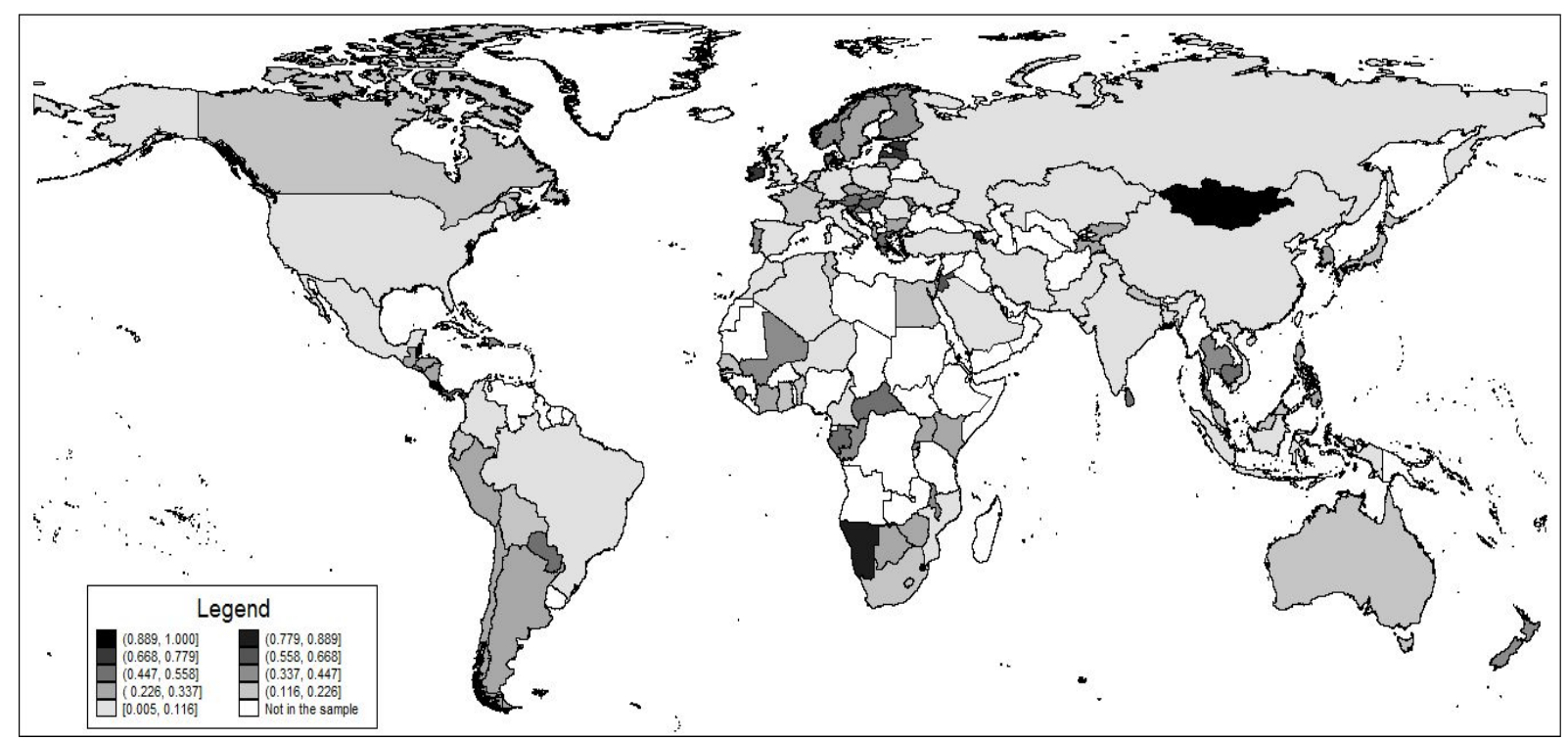

Notes: The map considers the variable for urban concentration defined in Equation (2), and entering Equation (1). Darker shades refer to higher values of the mapped variable. 
Figure A5: Variability of urban concentration within macro-region in the year 2000.

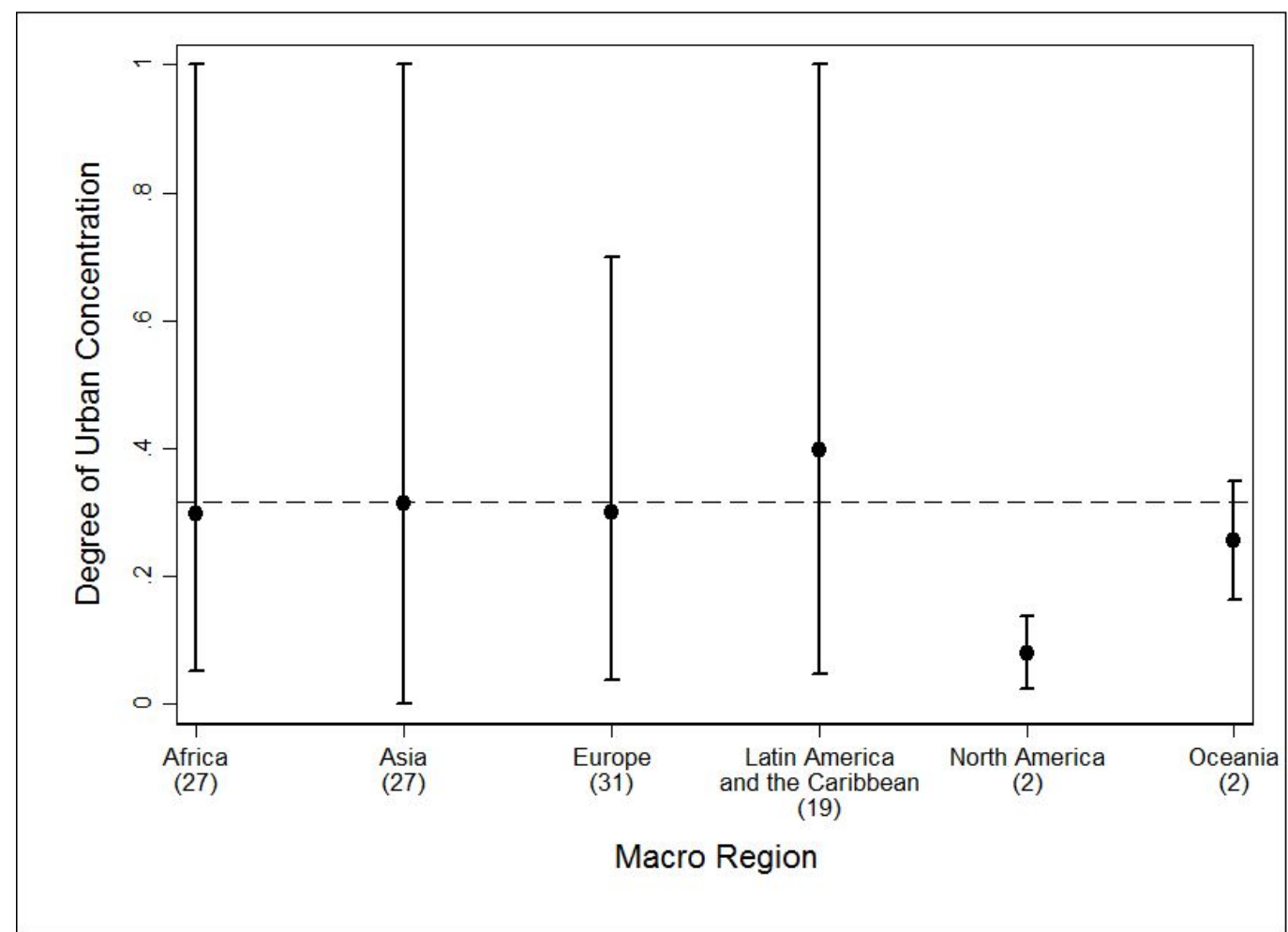

Notes: The plot considers the variable for urban concentration defined in Equation (2), and then standardised in the interval $[0,1]$. The dashed line refers to the sample mean. The circles denote macro-regions' mean values. The number of countries within each macroregion is reported in parentheses on the horizontal axis. Macro-regions are defined according to the taxonomy adopted by the United Nations. 
Figure A6: Spatial distribution of low- and high-income countries.

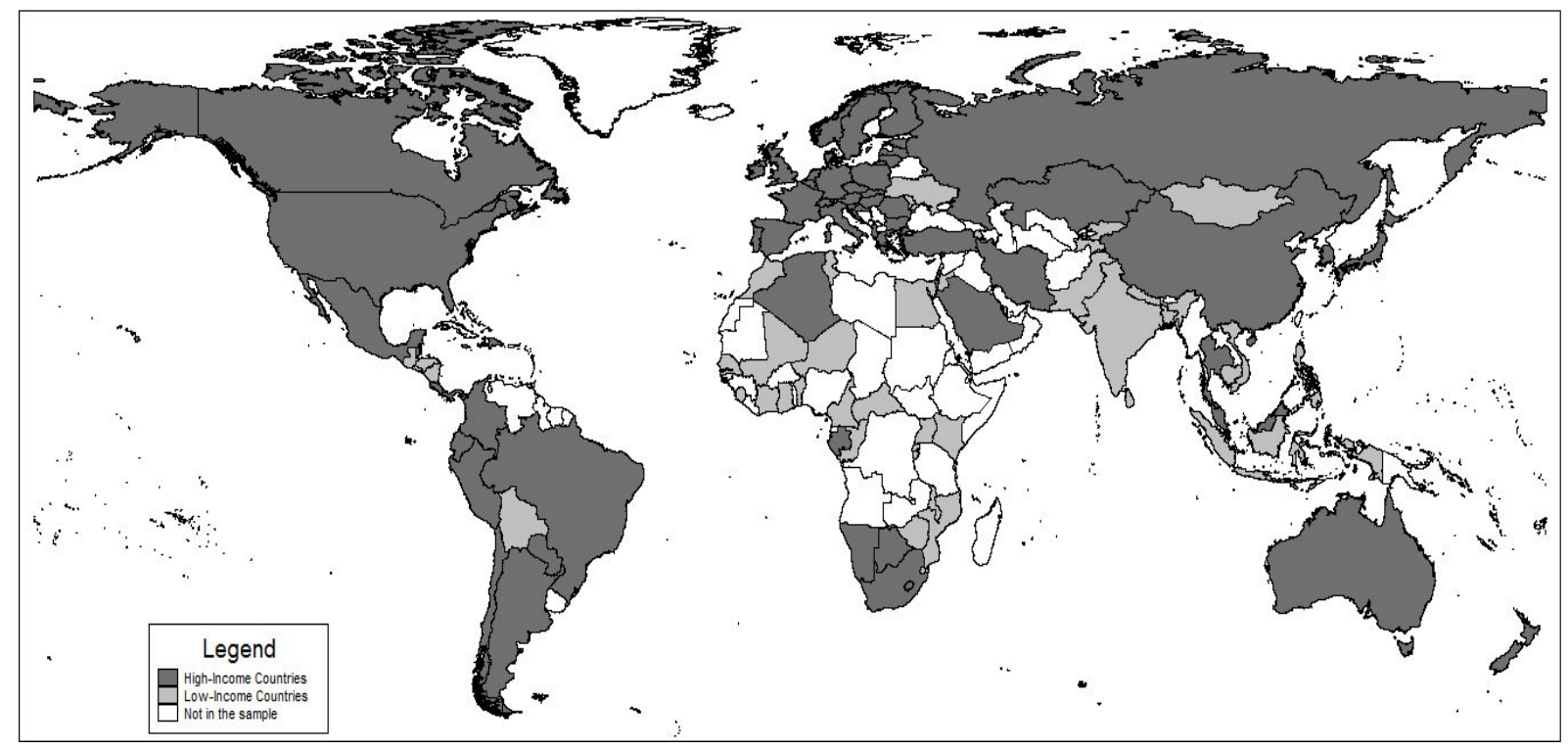

Notes: The map shows the classification of the countries in the sample according to the income level (i.e. low- vs. high-income) defined following the taxonomy adopted by the World Bank Group. Low-income countries are denoted in light grey, while high-income countries are denoted in dark grey. 


\section{ONLINE APPENDIX B - Main results}

Table B1: The economic returns of urban concentration - OLS estimates on all countries.

\begin{tabular}{|c|c|c|c|}
\hline Dependent Variable & $\Delta$ Employment $_{\mathrm{c}}$ & $\Delta$ GDP Per Capita ${ }_{c}$ & $\Delta$ Labour Productivity $_{c}$ \\
\hline \multirow{3}{*}{ Urban Concentration $_{\mathrm{c}}^{2000}$} & (1) & (2) & (3) \\
\hline & -0.009 & $0.015^{*}$ & $0.022 * *$ \\
\hline & $(0.006)$ & $(0.008)$ & $(0.009)$ \\
\hline \multirow[t]{2}{*}{$\log \left(\right.$ Employment $\left._{c}^{2000}\right)$} & $-0.003 * *$ & $\cdots$ & $\cdots$ \\
\hline & $(0.001)$ & & \\
\hline \multirow[t]{2}{*}{$\log \left(\right.$ GDP Per Capita $\left.{ }_{c}^{2000}\right)$} & $\ldots$ & $-0.016^{* * * *}$ & $\cdots$ \\
\hline & & $(0.003)$ & \\
\hline \multirow[t]{2}{*}{$\log \left(\right.$ Labour Productivity $\left.{ }_{c}^{2000}\right)$} & $\ldots$ & ... & $-0.016^{* * * *}$ \\
\hline & & & $(0.003)$ \\
\hline \multirow[t]{2}{*}{$\log \left(\right.$ Employment $_{\mathrm{c}}^{\text {Avg. }} 1991$ to 2000 $)$} & $\cdots$ & 0.004 & $0.004 *$ \\
\hline & & $(0.002)$ & $(0.002)$ \\
\hline \multirow[t]{2}{*}{$\log \left(\right.$ GDP Per Capita ${ }_{\mathrm{c}}^{\text {Avg. } 1990 \text { to } 2000)}$} & 0.000 & ... & $\ldots$ \\
\hline & $(0.002)$ & & \\
\hline \multirow[t]{2}{*}{ Gross Fixed Capital Formation to GDP Avg. 1990 to 2000} & -0.014 & 0.035 & 0.027 \\
\hline & $(0.024)$ & $(0.029)$ & $(0.028)$ \\
\hline \multirow[t]{2}{*}{ 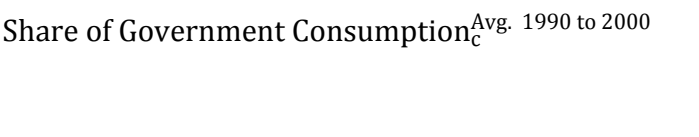 } & -0.012 & -0.007 & -0.004 \\
\hline & $(0.014)$ & $(0.023)$ & $(0.020)$ \\
\hline \multirow[t]{2}{*}{ Oil Rent to GDPAvg. 1990 to 2000} & $0.040^{* *}$ & -0.006 & -0.020 \\
\hline & $(0.016)$ & $(0.020)$ & $(0.018)$ \\
\hline \multirow[t]{2}{*}{ Openess ${ }_{\mathrm{c}}^{\text {Avg. }} 1990$ to 2000} & $0.010^{* *}$ & $0.013 * *$ & 0.008 \\
\hline & $(0.004)$ & $(0.005)$ & $(0.005)$ \\
\hline \multirow[t]{2}{*}{ Share of High Tech Export ${ }_{c}^{\text {Avg. }} 1990$ to 2000} & 0.003 & -0.015 & -0.005 \\
\hline & $(0.008)$ & $(0.010)$ & $(0.011)$ \\
\hline \multirow[t]{2}{*}{ High Income $_{c}(\mathrm{~d})$} & -0.002 & $0.015 * * *$ & $0.011^{* *}$ \\
\hline & $(0.003)$ & $(0.005)$ & $(0.005)$ \\
\hline \multirow[t]{2}{*}{ Population Density Avg. 1990 to 2000} & 0.000 & 0.000 & 0.000 \\
\hline & $(0.000)$ & $(0.000)$ & $(0.000)$ \\
\hline
\end{tabular}




\begin{tabular}{|c|c|c|c|}
\hline \multirow{2}{*}{ Years of Schooling Avg. 1990, 1995, 2000} & $-0.001^{*}$ & $0.003^{* * *}$ & $0.003^{* * *}$ \\
\hline & $(0.001)$ & $(0.001)$ & $(0.001)$ \\
\hline \multirow[t]{2}{*}{ Government Effectiveness $_{c}^{\text {Avg. }}$ 1996, 1998, 2000} & 0.001 & 0.003 & 0.002 \\
\hline & $(0.002)$ & $(0.003)$ & $(0.003)$ \\
\hline \multirow[t]{2}{*}{$\log \left(\right.$ Surface $\left._{c}\right)$} & $0.002 * *$ & 0.002 & 0.002 \\
\hline & $(0.001)$ & $(0.002)$ & $(0.002)$ \\
\hline \multirow[t]{2}{*}{ Island $_{c}(\mathrm{~d})$} & -0.000 & -0.000 & -0.000 \\
\hline & $(0.003)$ & $(0.005)$ & $(0.005)$ \\
\hline \multirow[t]{2}{*}{ Landlocked $_{c}(\mathrm{~d})$} & 0.003 & -0.004 & $-0.007 *$ \\
\hline & $(0.002)$ & $(0.003)$ & $(0.004)$ \\
\hline \multirow[t]{2}{*}{ Latitude $_{\mathrm{c}}$} & -0.000 & 0.000 & 0.000 \\
\hline & $(0.000)$ & $(0.000)$ & $(0.000)$ \\
\hline \multirow[t]{2}{*}{ Longitude $_{c}$} & $-0.000 * *$ & -0.000 & -0.000 \\
\hline & $(0.000)$ & $(0.000)$ & $(0.000)$ \\
\hline Macro-Region Dummies & Yes & Yes & Yes \\
\hline Number of Countries & 108 & 108 & 108 \\
\hline $\mathrm{R}^{2}$ & 0.67 & 0.62 & 0.61 \\
\hline Model F Statistic [p-value] & $15.60[0.000]$ & $14.97[0.000]$ & $9.39[0.000]$ \\
\hline
\end{tabular}

Notes: $* p<0.1 ; * * p<0.05 ; * * * p<0.01 ; * * * * p<0.001$. Robust standard errors are reported in parentheses. All specifications include a constant term. (d) denotes a binary variable. Table A2 (Online Appendix A) reports the definition of the variables. 
Table B2: The economic returns of urban concentration - TSLS estimates on all countries.

\begin{tabular}{|c|c|c|c|}
\hline Dependent Variable & " $\Delta$ Employment $_{\mathrm{c}}$ & $\Delta$ AGDP Per Capita $_{\mathrm{c}}$ & 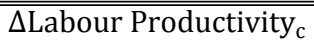 \\
\hline & (1) & (2) & (3) \\
\hline \multirow[t]{2}{*}{ Urban Concentration $_{\mathrm{c}}^{2000}$} & $-0.030^{* *}$ & $0.060^{* * *}$ & $0.085^{* * * *}$ \\
\hline & $(0.013)$ & $(0.019)$ & $(0.020)$ \\
\hline \multirow[t]{2}{*}{$\log \left(\right.$ Employment $\left._{\mathrm{c}}^{2000}\right)$} & $-0.006^{* * *}$ & .. & $\cdots$ \\
\hline & $(0.002)$ & & \\
\hline \multirow[t]{2}{*}{$\log \left(\right.$ GDP Per Capita $\left.{ }_{c}^{2000}\right)$} & $\cdots$ & $-0.019 * * * *$ & $\cdots$ \\
\hline & & $(0.003)$ & \\
\hline \multirow[t]{2}{*}{$\log \left(\right.$ Labour Productivity $\left._{c}^{2000}\right)$} & $\ldots$ & $\ldots$ & $-0.018 * * * *$ \\
\hline & & & $(0.003)$ \\
\hline \multirow[t]{2}{*}{$\log \left(\right.$ Employment $\left._{\mathrm{c}}^{\text {Avg. } 1991 \text { to 2000 }}\right)$} & $\cdots$ & $0.010 * * * *$ & $0.013 * * * *$ \\
\hline & & $(0.003)$ & $(0.003)$ \\
\hline \multirow[t]{2}{*}{$\log \left(\right.$ GDP Per Capita ${ }_{c}^{\text {Avg. }} 1990$ to 2000$)$} & 0.001 & .. & $\ldots$ \\
\hline & $(0.002)$ & & \\
\hline \multirow[t]{2}{*}{ Gross Fixed Capital Formation to GDP Avg. 1990 to 2000} & -0.009 & 0.027 & 0.018 \\
\hline & $(0.026)$ & $(0.037)$ & $(0.041)$ \\
\hline \multirow[t]{2}{*}{ 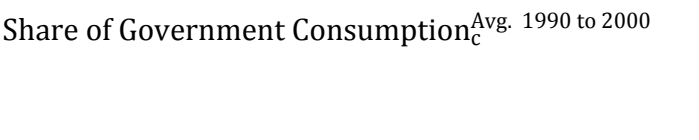 } & -0.008 & -0.020 & -0.021 \\
\hline & $(0.015)$ & $(0.027)$ & $(0.026)$ \\
\hline \multirow[t]{2}{*}{ Oil Rent to GDP Avg. 1990 to 2000} & $0.028^{*}$ & 0.024 & 0.018 \\
\hline & $(0.015)$ & $(0.025)$ & $(0.026)$ \\
\hline \multirow[t]{2}{*}{ 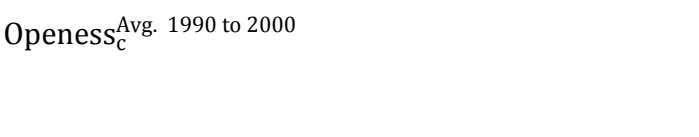 } & $0.010^{* *}$ & $0.014 * * *$ & 0.009 \\
\hline & $(0.005)$ & $(0.005)$ & $(0.006)$ \\
\hline \multirow[t]{2}{*}{ Share of High Tech Export ${ }_{c}^{\text {Avg. } 1990 ~ t o ~} 2000$} & 0.005 & $-0.020^{*}$ & -0.012 \\
\hline & $(0.010)$ & $(0.012)$ & $(0.015)$ \\
\hline \multirow[t]{2}{*}{ High Income $_{c}(d)$} & -0.002 & $0.017 * * *$ & $0.013 * *$ \\
\hline & $(0.003)$ & $(0.005)$ & $(0.006)$ \\
\hline \multirow[t]{2}{*}{ Population Density Avg. 1990 to 2000} & 0.000 & 0.000 & -0.000 \\
\hline & $(0.000)$ & $(0.000)$ & $(0.000)$ \\
\hline \multirow[t]{2}{*}{ Years of Schooling Avg. 1990, 1995, 2000} & $-0.002 * *$ & $0.004^{* * *}$ & $0.004 * * *$ \\
\hline & $(0.001)$ & $(0.001)$ & $(0.001)$ \\
\hline
\end{tabular}




\begin{tabular}{|c|c|c|c|}
\hline \multirow[t]{2}{*}{ 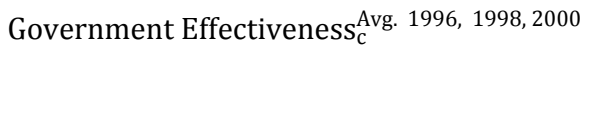 } & 0.002 & 0.003 & 0.002 \\
\hline & $(0.002)$ & $(0.003)$ & $(0.003)$ \\
\hline \multirow[t]{2}{*}{$\log \left(\right.$ Surface $\left._{c}\right)$} & $0.002 *$ & 0.002 & 0.002 \\
\hline & $(0.001)$ & $(0.002)$ & $(0.002)$ \\
\hline \multirow[t]{2}{*}{$\operatorname{Island}_{c}(\mathrm{~d})$} & 0.000 & -0.001 & -0.001 \\
\hline & $(0.003)$ & $(0.005)$ & $(0.005)$ \\
\hline \multirow[t]{2}{*}{ Landlocked $_{c}(\mathrm{~d})$} & 0.003 & -0.003 & -0.006 \\
\hline & $(0.002)$ & $(0.004)$ & $(0.005)$ \\
\hline \multirow[t]{2}{*}{ Latitude $_{c}$} & -0.000 & 0.000 & 0.000 \\
\hline & $(0.000)$ & $(0.000)$ & $(0.000)$ \\
\hline \multirow[t]{2}{*}{ Longitude $_{c}$} & -0.000 & $-0.000^{*}$ & $-0.000 * * *$ \\
\hline & $(0.000)$ & $(0.000)$ & $(0.000)$ \\
\hline Macro-Region Dummies & Yes & Yes & Yes \\
\hline Number of Countries & 108 & 108 & 108 \\
\hline $\mathrm{R}^{2}$ & 0.62 & 0.50 & 0.38 \\
\hline \multirow[t]{2}{*}{ Model F Statistic [p-value] } & $15.66[0.000]$ & $13.15[0.000]$ & $15.72[0.000]$ \\
\hline & & & \\
\hline \multirow[t]{2}{*}{ Area Equipped for Irrigation $_{c}^{1900}$} & $0.199 * * * *$ & $0.201 * * * *$ & $0.200 * * * *$ \\
\hline & $(0.042)$ & $(0.039)$ & $(0.043)$ \\
\hline First-Stage F Statistic on Excluded IV [p-value] & $22.12[0.000]$ & $26.52[0.000]$ & $21.47[0.000]$ \\
\hline
\end{tabular}

\footnotetext{
Notes: $* p<0.1 ; * *<<0.05 ; * * * p<0.01 ; * * * * p<0.001$. Robust standard errors are reported in parentheses. All specifications include a constant term. (d) denotes a binary variable. Table A2 (Online Appendix A) reports the definition of the variables. The full set of firststage estimates is available upon request.
} 
Table B3: The economic returns of urban concentration in low- vs. high-income countries.

\begin{tabular}{|c|c|c|c|c|c|c|}
\hline \multirow{2}{*}{$\begin{array}{l}\text { Dependent Variable } \\
\text { Low- vs. High-Income Countries }\end{array}$} & \multicolumn{2}{|c|}{ 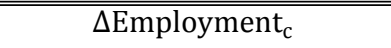 } & \multicolumn{2}{|c|}{$\Delta$ GGDP Per Capita $_{\mathrm{c}}$} & \multicolumn{2}{|c|}{ 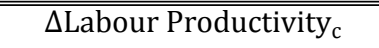 } \\
\hline & Low-Income & High-Income & Low-Income & High-Income & Low-Income & High-Income \\
\hline \multirow{3}{*}{ Urban Concentration $_{\mathrm{c}}^{2000}$} & (1) & (2) & (3) & (4) & (5) & (6) \\
\hline & -0.029 & $-0.042 * * *$ & $0.049 * *$ & $0.080 * * *$ & $0.077 * * *$ & $0.108 * * * *$ \\
\hline & $(0.019)$ & $(0.015)$ & $(0.021)$ & $(0.027)$ & $(0.025)$ & $(0.032)$ \\
\hline \multirow[t]{2}{*}{$\log \left(\right.$ Employment $\left._{\mathrm{c}}^{2000}\right)$} & -0.005 & $-0.007 * * *$ & $\ldots$ & $\ldots$ & $\ldots$ & $\ldots$ \\
\hline & $(0.004)$ & $(0.002)$ & & & & \\
\hline \multirow[t]{2}{*}{$\log \left(\right.$ GDP Per Capita $\left.{ }_{c}^{2000}\right)$} & $\cdots$ & $\cdots$ & $-0.016^{* * *}$ & $-0.022 * * * *$ & $\cdots$ & $\cdots$ \\
\hline & & & $(0.006)$ & $(0.004)$ & & \\
\hline \multirow[t]{2}{*}{$\log \left(\right.$ Labour Productivity $\left.y_{c}^{2000}\right)$} & $\ldots$ & $\cdots$ & $\ldots$ & $\ldots$ & $-0.018^{* * * *}$ & $-0.019 * * * *$ \\
\hline & & & & & $(0.005)$ & $(0.004)$ \\
\hline \multirow[t]{2}{*}{$\log \left(\right.$ Employment $\left.\mathrm{c}_{\mathrm{c}}^{\text {Avg. } 1991 \text { to } 2000}\right)$} & $\cdots$ & $\cdots$ & $0.009 * *$ & $0.013^{* * * *}$ & $0.012 * * *$ & $0.017 * * * *$ \\
\hline & & & $(0.004)$ & $(0.004)$ & $(0.004)$ & $(0.005)$ \\
\hline \multirow[t]{2}{*}{$\log ($ GDP Per Capita Avg. 1990 to 2000) } & 0.001 & -0.001 & $\cdots$ & $\cdots$ & $\cdots$ & $\cdots$ \\
\hline & $(0.003)$ & $(0.002)$ & & & & \\
\hline \multirow[t]{2}{*}{ Gross Fixed Capital Formation to $\mathrm{GDP}_{\mathrm{c}}^{\text {Avg. }} 1990$ to 2000} & -0.024 & 0.035 & $0.110^{*}$ & $-0.089 *$ & $0.100^{*}$ & $-0.108^{* *}$ \\
\hline & $(0.060)$ & $(0.026)$ & $(0.065)$ & $(0.051)$ & $(0.055)$ & $(0.054)$ \\
\hline \multirow[t]{2}{*}{ 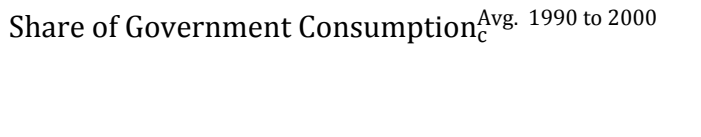 } & -0.052 & 0.015 & $0.079 *$ & -0.068 & $0.121 * * *$ & $-0.097 *$ \\
\hline & $(0.038)$ & $(0.021)$ & $(0.044)$ & $(0.044)$ & $(0.042)$ & $(0.051)$ \\
\hline \multirow[t]{2}{*}{ Oil Rent to GDP Avg. 1990 to 2000} & 0.041 & $0.042 *$ & -0.021 & 0.042 & -0.041 & 0.044 \\
\hline & $(0.030)$ & $(0.025)$ & $(0.045)$ & $(0.034)$ & $(0.039)$ & $(0.043)$ \\
\hline \multirow[t]{2}{*}{ 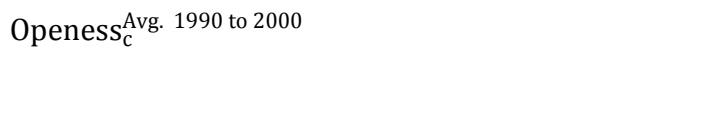 } & $0.019 * *$ & 0.001 & 0.004 & $0.022 * * *$ & 0.001 & $0.024 * * *$ \\
\hline & $(0.009)$ & $(0.004)$ & $(0.014)$ & $(0.008)$ & $(0.013)$ & $(0.009)$ \\
\hline \multirow[t]{2}{*}{ Share of High Tech Export ${ }_{c}^{\text {Avg. }} 1990$ to 2000} & 0.012 & $0.027^{*}$ & 0.012 & $-0.059 * *$ & 0.020 & $-0.073 * *$ \\
\hline & $(0.014)$ & $(0.015)$ & $(0.031)$ & $(0.027)$ & $(0.033)$ & $(0.033)$ \\
\hline \multirow[t]{2}{*}{ Population Densityc Avg. 1990 to 2000} & 0.000 & -0.000 & -0.000 & 0.000 & -0.000 & 0.000 \\
\hline & $(0.000)$ & $(0.000)$ & $(0.000)$ & $(0.000)$ & $(0.000)$ & $(0.000)$ \\
\hline \multirow[t]{2}{*}{ Years of Schooling ${ }_{c}^{\text {Avg. }}$ 1990, 1995, 2000} & -0.002 & -0.001 & 0.000 & $0.006 * * *$ & 0.000 & $0.007 * * *$ \\
\hline & $(0.001)$ & $(0.001)$ & $(0.002)$ & $(0.002)$ & $(0.002)$ & $(0.002)$ \\
\hline 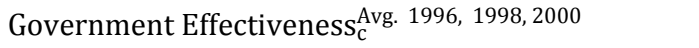 & 0.002 & 0.004 & 0.006 & 0.005 & 0.009 & 0.001 \\
\hline
\end{tabular}




\begin{tabular}{|c|c|c|c|c|c|c|}
\hline & $(0.004)$ & $(0.003)$ & $(0.006)$ & $(0.005)$ & $(0.007)$ & $(0.005)$ \\
\hline \multirow[t]{2}{*}{$\log \left(\right.$ Surface $\left._{c}\right)$} & 0.002 & 0.001 & -0.002 & 0.003 & -0.001 & 0.002 \\
\hline & $(0.002)$ & $(0.002)$ & $(0.003)$ & $(0.003)$ & $(0.003)$ & $(0.004)$ \\
\hline \multirow[t]{2}{*}{ Island $_{c}(\mathrm{~d})$} & 0.007 & -0.002 & -0.008 & -0.002 & -0.011 & -0.001 \\
\hline & $(0.008)$ & $(0.003)$ & $(0.012)$ & $(0.006)$ & $(0.011)$ & $(0.006)$ \\
\hline \multirow[t]{2}{*}{ Landlocked $_{c}(\mathrm{~d})$} & 0.010 & 0.001 & $-0.014 * *$ & 0.005 & $-0.024 * * *$ & 0.002 \\
\hline & $(0.006)$ & $(0.003)$ & $(0.007)$ & $(0.006)$ & $(0.007)$ & $(0.007)$ \\
\hline \multirow[t]{2}{*}{ Latitude $_{c}$} & -0.000 & 0.000 & 0.000 & 0.000 & 0.000 & 0.000 \\
\hline & $(0.000)$ & $(0.000)$ & $(0.000)$ & $(0.000)$ & $(0.000)$ & $(0.000)$ \\
\hline \multirow[t]{2}{*}{ Longitude $_{c}$} & -0.000 & -0.000 & 0.000 & -0.000 & 0.000 & $-0.000 *$ \\
\hline & $(0.000)$ & $(0.000)$ & $(0.000)$ & $(0.000)$ & $(0.000)$ & $(0.000)$ \\
\hline Macro-Region Dummies & Yes & Yes & Yes & Yes & Yes & Yes \\
\hline Number of Countries & 44 & 64 & 44 & 64 & 44 & 64 \\
\hline $\mathrm{R}^{2}$ & 0.56 & 0.72 & 0.64 & 0.53 & 0.64 & 0.38 \\
\hline Model F Statistic [p-value] & $16.46[0.000]$ & $8.16[0.000]$ & $21.17[0.000]$ & $22.70[0.000]$ & $18.41[0.000]$ & $27.44[0.000]$ \\
\hline \multirow[t]{2}{*}{ Equality of Urban Concentration ${ }_{c}^{2000}$ (p-value) } & \multicolumn{2}{|c|}{0.011} & \multicolumn{2}{|c|}{0.001} & \multicolumn{2}{|c|}{0.018} \\
\hline & & & & & & \\
\hline \multirow[t]{2}{*}{ Area Equipped for Irrigation ${ }_{\mathrm{c}}^{1900}$} & $0.217 * * * *$ & $0.206^{* * *}$ & $0.217 * * * *$ & $0.197 * * *$ & $0.210^{* * * *}$ & $0.195 * * *$ \\
\hline & $(0.051)$ & $(0.065)$ & $(0.049)$ & $(0.059)$ & $(0.050)$ & $(0.061)$ \\
\hline First-Stage F Statistic on Excluded IV [p-value] & $17.96[0.000]$ & $10.07[0.003]$ & $19.36[0.000]$ & $11.21[0.002]$ & $17.37[0.000]$ & $10.31[0.003]$ \\
\hline
\end{tabular}

Notes: $* p<0.1 ; * * p<0.05 ; * * * p<0.01 ; * * * * p<0.001$. TSLS estimates. Robust standard errors are reported in parentheses. All specifications include a constant term. (d) denotes a binary variable. Low- and high-income countries are classified according the World Bank Group's taxonomy. The test of equal urban concentration coefficients for low- vs. high-income countries is obtained through bootstrapping (1,000 replications). Table A2 (Online Appendix A) reports the definition of the variables. The full set of first-stage estimates is available upon request. 
Table B4: The short-run economic returns (five-year growth rates) of urban concentration in low- vs. high-income countries.

\begin{tabular}{|c|c|c|c|c|c|c|}
\hline \multirow{3}{*}{$\begin{array}{l}\text { Growth Period of Dependent Variable } \\
\text { Dependent Variable } \\
\text { Low- vs. High-Income Countries }\end{array}$} & \multicolumn{6}{|c|}{$2000-2005$} \\
\hline & \multicolumn{2}{|c|}{$\Delta$ Employment $_{c}$} & \multicolumn{2}{|c|}{$\Delta$ GDP Per Capita ${ }_{c}$} & \multicolumn{2}{|c|}{$\Delta$ Labour Productivity $_{c}$} \\
\hline & Low-Income & High-Income & Low-Income & High-Income & Low-Income & High-Income \\
\hline & (1) & (2) & (3) & (4) & (5) & (6) \\
\hline \multirow[t]{2}{*}{ Urban Concentration $_{c}^{2000}$} & 0.009 & -0.028 & 0.048 & $0.063^{* *}$ & 0.044 & $0.070^{*}$ \\
\hline & $(0.021)$ & $(0.027)$ & $(0.037)$ & $(0.026)$ & $(0.040)$ & $(0.038)$ \\
\hline \multirow[t]{2}{*}{$\log \left(\right.$ Employment $\left._{c}^{2000}\right)$} & 0.000 & -0.007 & $\ldots$ & $\ldots$ & $\ldots$ & $\ldots$ \\
\hline & $(0.004)$ & $(0.004)$ & & & & \\
\hline \multirow[t]{2}{*}{$\log \left(\right.$ GDP Per Capita $\left.{ }_{c}^{2000}\right)$} & $\ldots$ & $\ldots$ & -0.014 & $-0.023 * * * *$ & $\ldots$ & $\ldots$ \\
\hline & & & $(0.011)$ & $(0.004)$ & & \\
\hline \multirow[t]{2}{*}{$\log \left(\right.$ Labour Productivity $\left.{ }^{2000}\right)$} & $\ldots$ & $\ldots$ & $\ldots$ & $\ldots$ & -0.014 & $-0.025^{* * * *}$ \\
\hline & & & & & $(0.009)$ & $(0.005)$ \\
\hline \multirow[t]{2}{*}{$\log ($ Employment Avg. 1991 to 2000$)$} & $\ldots$ & $\ldots$ & 0.005 & 0.006 & 0.005 & 0.009 \\
\hline & & & $(0.007)$ & $(0.004)$ & $(0.006)$ & $(0.006)$ \\
\hline \multirow[t]{2}{*}{$\log \left(\right.$ GDP Per Capita ${ }_{c}^{\text {Avg. }} 1990$ to 2000) } & -0.002 & 0.002 & $\ldots$ & $\ldots$ & $\ldots$ & $\ldots$ \\
\hline & $(0.004)$ & $(0.003)$ & & & & \\
\hline \multirow[t]{2}{*}{ Gross Fixed Capital Formation to GDP Acg. 1990 to 2000} & $-0.137^{*}$ & $0.099^{* *}$ & $0.286^{* * *}$ & -0.080 & $0.344 * * * *$ & $-0.147^{* *}$ \\
\hline & $(0.074)$ & $(0.043)$ & $(0.092)$ & $(0.053)$ & $(0.066)$ & $(0.059)$ \\
\hline \multirow[t]{2}{*}{ Share of Government Consumption ${ }_{c}^{\text {Avg. }} 1990$ to 2000} & $-0.072^{* *}$ & 0.032 & 0.089 & 0.026 & 0.122 & -0.023 \\
\hline & $(0.037)$ & $(0.029)$ & $(0.078)$ & $(0.047)$ & $(0.074)$ & $(0.049)$ \\
\hline
\end{tabular}




\begin{tabular}{|c|c|c|c|c|c|c|}
\hline \multirow[t]{2}{*}{ Oil Rent to GDP ${ }_{c}^{\text {Avg. }} 1990$ to 2000} & $0.090 * * *$ & 0.032 & -0.073 & -0.015 & $-0.111^{*}$ & -0.004 \\
\hline & $(0.030)$ & $(0.044)$ & $(0.073)$ & $(0.032)$ & $(0.064)$ & $(0.051)$ \\
\hline \multirow[t]{2}{*}{ Openess ${ }_{\mathrm{c}}^{\text {Avg. }} 1990$ to 2000} & 0.010 & -0.001 & -0.009 & 0.010 & -0.002 & 0.011 \\
\hline & $(0.014)$ & $(0.007)$ & $(0.023)$ & $(0.007)$ & $(0.020)$ & $(0.011)$ \\
\hline \multirow[t]{2}{*}{ Share of High Tech Export Avg. $_{c}^{\text {Avg }} 1990$ to 2000} & 0.020 & 0.029 & 0.043 & -0.037 & 0.050 & -0.048 \\
\hline & $(0.020)$ & $(0.021)$ & $(0.036)$ & $(0.024)$ & $(0.032)$ & $(0.031)$ \\
\hline \multirow[t]{2}{*}{ Population DensityAdg. 1990 to 2000} & 0.000 & -0.000 & -0.000 & 0.000 & -0.000 & -0.000 \\
\hline & $(0.000)$ & $(0.000)$ & $(0.000)$ & $(0.000)$ & $(0.000)$ & $(0.000)$ \\
\hline \multirow[t]{2}{*}{ Years of Schooling Avg. 1990, 1995, 2000} & 0.001 & -0.003 & -0.002 & $0.005^{* * *}$ & -0.004 & $0.007^{* * *}$ \\
\hline & $(0.001)$ & $(0.002)$ & $(0.003)$ & $(0.002)$ & $(0.004)$ & $(0.002)$ \\
\hline \multirow[t]{2}{*}{ Government Effectiveness Avg. 1996, 1998, 2000} & 0.006 & 0.000 & -0.008 & 0.003 & -0.012 & 0.004 \\
\hline & $(0.004)$ & $(0.005)$ & $(0.011)$ & $(0.005)$ & $(0.010)$ & $(0.006)$ \\
\hline \multirow[t]{2}{*}{$\log \left(\right.$ Surface $\left._{c}\right)$} & 0.002 & 0.003 & -0.006 & 0.005 & -0.005 & 0.002 \\
\hline & $(0.002)$ & $(0.002)$ & $(0.004)$ & $(0.003)$ & $(0.004)$ & $(0.003)$ \\
\hline \multirow[t]{2}{*}{ Island $_{c}(\mathrm{~d})$} & 0.003 & 0.006 & -0.020 & 0.004 & -0.013 & -0.002 \\
\hline & $(0.009)$ & $(0.005)$ & $(0.018)$ & $(0.005)$ & $(0.015)$ & $(0.005)$ \\
\hline \multirow[t]{2}{*}{ Landlocked $_{c}(\mathrm{~d})$} & 0.007 & -0.004 & -0.018 & 0.002 & -0.022 & 0.003 \\
\hline & $(0.006)$ & $(0.003)$ & $(0.016)$ & $(0.007)$ & $(0.017)$ & $(0.006)$ \\
\hline \multirow[t]{2}{*}{ Latitude $_{c}$} & 0.000 & -0.000 & 0.000 & 0.000 & 0.000 & 0.000 \\
\hline & $(0.000)$ & $(0.000)$ & $(0.000)$ & $(0.000)$ & $(0.001)$ & $(0.000)$ \\
\hline Longitude $_{c}$ & $-0.000 *$ & -0.000 & 0.000 & -0.000 & 0.000 & -0.000 \\
\hline
\end{tabular}




\begin{tabular}{|c|c|c|c|c|c|c|}
\hline & $(0.000)$ & $(0.000)$ & $(0.000)$ & $(0.000)$ & $(0.000)$ & $(0.000)$ \\
\hline Macro-Region Dummies & Yes & Yes & Yes & Yes & Yes & Yes \\
\hline Number of Countries & 44 & 64 & 44 & 64 & 44 & 64 \\
\hline $\mathrm{R}^{2}$ & 0.47 & 0.56 & 0.57 & 0.74 & 0.53 & 0.71 \\
\hline Model F Statistic [p-value] & $12.55[0.000]$ & $5.51[0.000]$ & $5.78[0.000]$ & $45.55[0.000]$ & $9.11[0.000]$ & $44.31[0.000]$ \\
\hline Equality of Urban Concentration ${ }_{c}^{2000}$ (p-value) & \multicolumn{2}{|c|}{0.093} & \multicolumn{2}{|c|}{0.060} & \multicolumn{2}{|c|}{0.002} \\
\hline First-Stage Estimation & & & & & & \\
\hline \multirow[t]{2}{*}{ Area Equipped for Irrigation ${ }_{c}^{1900}$} & $0.217 * * * *$ & $0.206^{* * *}$ & $0.217 * * * *$ & $0.197^{* * *}$ & $0.210 * * * *$ & $0.195^{* * *}$ \\
\hline & $(0.051)$ & $(0.065)$ & $(0.049)$ & $(0.059)$ & $(0.050)$ & $(0.061)$ \\
\hline First-Stage F Statistic on Excluded IV [p-value] & $17.96[0.000]$ & $10.07[0.003]$ & $19.36[0.000]$ & $11.21[0.002]$ & $17.37[0.000]$ & $10.31[0.003]$ \\
\hline
\end{tabular}

Notes: $* p<0.1 ; * * p<0.05 ; * * * p<0.01 ; * * * * p<0.001$. TSLS estimates. Robust standard errors are reported in parentheses. All specifications include a constant term. (d) denotes a binary variable. Low- and high-income countries are classified according the World Bank Group's taxonomy. The test of equal urban concentration coefficients for low- vs. high-income countries is obtained through bootstrapping (1,000 replications). Table A2 (Online Appendix A) reports the definition of the variables. The full set of first-stage estimates is available upon request.

Table B5: The mid-run economic returns (eight-year growth rates) of urban concentration in low- vs. high-income countries. 


\begin{tabular}{|c|c|c|c|c|c|c|}
\hline \multirow{3}{*}{$\begin{array}{l}\text { Growth Period of Dependent Variable } \\
\text { Dependent Variable } \\
\text { Low- vs. High-Income Countries }\end{array}$} & \multicolumn{6}{|c|}{$2000-2008$} \\
\hline & \multicolumn{2}{|c|}{$\Delta$ Employment $_{\mathrm{c}}$} & \multicolumn{2}{|c|}{$\Delta$ GDP Per Capita ${ }_{c}$} & \multicolumn{2}{|c|}{$\Delta$ Labour Productivity $_{c}$} \\
\hline & Low-Income & High-Income & Low-Income & High-Income & Low-Income & High-Income \\
\hline & (1) & (2) & (3) & (4) & (5) & (6) \\
\hline \multirow[t]{2}{*}{ Urban Concentration $_{c}^{2000}$} & -0.019 & -0.027 & 0.055 & $0.071 * *$ & $0.081^{*}$ & $0.082 * *$ \\
\hline & $(0.023)$ & $(0.018)$ & $(0.039)$ & $(0.028)$ & $(0.043)$ & $(0.038)$ \\
\hline \multirow[t]{2}{*}{$\log \left(\right.$ Employment $\left._{c}^{2000}\right)$} & -0.003 & $-0.005^{* *}$ & $\ldots$ & $\cdots$ & $\ldots$ & $\ldots$ \\
\hline & $(0.005)$ & $(0.003)$ & & & & \\
\hline \multirow[t]{2}{*}{$\log \left(\right.$ GDP Per Capita $\left.{ }_{c}^{2000}\right)$} & $\cdots$ & $\cdots$ & $-0.019^{*}$ & $-0.025 * * * *$ & $\ldots$ & $\ldots$ \\
\hline & & & $(0.011)$ & $(0.004)$ & & \\
\hline \multirow[t]{2}{*}{$\log \left(\right.$ Labour Productivity $\left.{ }_{c}^{2000}\right)$} & $\cdots$ & $\cdots$ & $\cdots$ & $\cdots$ & $-0.020 * *$ & $-0.025^{* * * *}$ \\
\hline & & & & & $(0.010)$ & $(0.005)$ \\
\hline \multirow[t]{2}{*}{$\log \left(\right.$ Employment $\left._{\mathrm{c}}^{\text {Avg. } 1991 \text { to } 2000}\right)$} & $\ldots$ & $\cdots$ & 0.007 & $0.010^{* * *}$ & 0.011 & $0.012 * *$ \\
\hline & & & $(0.006)$ & $(0.004)$ & $(0.007)$ & $(0.005)$ \\
\hline \multirow[t]{2}{*}{$\log \left(\right.$ GDP Per Capita ${ }_{\mathrm{c}}^{\text {Avg. }} 1990$ to 2000$)$} & -0.000 & 0.001 & $\cdots$ & $\cdots$ & $\cdots$ & $\cdots$ \\
\hline & $(0.004)$ & $(0.002)$ & & & & \\
\hline \multirow[t]{2}{*}{ Gross Fixed Capital Formation to GDP Avg. 1990 to 2000} & -0.122 & 0.052 & $0.225^{* * *}$ & $-0.110^{* *}$ & $0.277 * * * *$ & $-0.128^{* *}$ \\
\hline & $(0.082)$ & $(0.033)$ & $(0.080)$ & $(0.052)$ & $(0.066)$ & $(0.054)$ \\
\hline \multirow[t]{2}{*}{ Share of Government Consumption ${ }_{\mathrm{c}}^{\text {Avg. }} 1990$ to 2000} & -0.063 & 0.024 & 0.073 & -0.031 & 0.113 & -0.070 \\
\hline & $(0.042)$ & $(0.023)$ & $(0.072)$ & $(0.051)$ & $(0.071)$ & $(0.053)$ \\
\hline 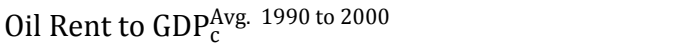 & $0.083^{* *}$ & 0.019 & -0.035 & 0.001 & -0.076 & 0.024 \\
\hline
\end{tabular}




\begin{tabular}{|c|c|c|c|c|c|c|}
\hline & $(0.038)$ & $(0.029)$ & $(0.073)$ & $(0.033)$ & $(0.068)$ & $(0.043)$ \\
\hline \multirow[t]{2}{*}{ Openess scrg. 1990 to 2000} & $0.022^{*}$ & 0.003 & -0.009 & $0.017^{* *}$ & -0.011 & 0.015 \\
\hline & $(0.013)$ & $(0.005)$ & $(0.022)$ & $(0.008)$ & $(0.020)$ & $(0.010)$ \\
\hline \multirow[t]{2}{*}{ Share of High Tech Export Avg. 1990 to 2000} & 0.004 & 0.017 & 0.018 & $-0.076^{* * *}$ & 0.040 & $-0.075^{* *}$ \\
\hline & $(0.017)$ & $(0.015)$ & $(0.036)$ & $(0.027)$ & $(0.036)$ & $(0.034)$ \\
\hline \multirow[t]{2}{*}{ Population Density ${ }_{c}^{\text {Avg. }} 1990$ to 2000} & 0.000 & -0.000 & -0.000 & -0.000 & -0.000 & 0.000 \\
\hline & $(0.000)$ & $(0.000)$ & $(0.000)$ & $(0.000)$ & $(0.000)$ & $(0.000)$ \\
\hline \multirow{2}{*}{ Years of Schooling Avg. 1990, 1995, 2000} & -0.001 & -0.001 & -0.000 & $0.007 * * * *$ & -0.002 & $0.007 * * *$ \\
\hline & $(0.002)$ & $(0.001)$ & $(0.003)$ & $(0.002)$ & $(0.004)$ & $(0.002)$ \\
\hline \multirow{2}{*}{ Government Effectiveness Avg. 1996, 1998, 2000} & 0.006 & 0.002 & -0.001 & 0.004 & -0.003 & 0.003 \\
\hline & $(0.005)$ & $(0.003)$ & $(0.011)$ & $(0.005)$ & $(0.010)$ & $(0.005)$ \\
\hline \multirow[t]{2}{*}{$\log \left(\right.$ Surface $\left._{c}\right)$} & 0.003 & 0.002 & -0.006 & 0.003 & -0.006 & 0.003 \\
\hline & $(0.002)$ & $(0.002)$ & $(0.004)$ & $(0.003)$ & $(0.004)$ & $(0.003)$ \\
\hline \multirow[t]{2}{*}{ Island $_{c}$ (d) } & 0.013 & 0.000 & -0.009 & -0.003 & -0.013 & -0.003 \\
\hline & $(0.011)$ & $(0.004)$ & $(0.018)$ & $(0.005)$ & $(0.018)$ & $(0.005)$ \\
\hline \multirow[t]{2}{*}{ Landlocked $_{c}(\mathrm{~d})$} & 0.008 & -0.004 & -0.015 & 0.003 & -0.021 & 0.004 \\
\hline & $(0.007)$ & $(0.003)$ & $(0.015)$ & $(0.007)$ & $(0.016)$ & $(0.006)$ \\
\hline \multirow[t]{2}{*}{ Latitude $_{c}$} & 0.000 & 0.000 & 0.001 & 0.000 & 0.000 & 0.000 \\
\hline & $(0.000)$ & $(0.000)$ & $(0.000)$ & $(0.000)$ & $(0.001)$ & $(0.000)$ \\
\hline \multirow[t]{2}{*}{ Longitude $_{c}$} & -0.000 & -0.000 & 0.000 & 0.000 & 0.000 & -0.000 \\
\hline & $(0.000)$ & $(0.000)$ & $(0.000)$ & $(0.000)$ & $(0.000)$ & $(0.000)$ \\
\hline
\end{tabular}




\begin{tabular}{|c|c|c|c|c|c|c|}
\hline Macro-Region Dummies & Yes & Yes & Yes & Yes & Yes & Yes \\
\hline Number of Countries & 44 & 64 & 44 & 64 & 44 & 64 \\
\hline $\mathrm{R}^{2}$ & 0.55 & 0.60 & 0.55 & 0.71 & 0.53 & 0.67 \\
\hline Model F Statistic [p-value] & $5.04[0.000]$ & $6.70[0.000]$ & $6.18[0.000]$ & $59.12[0.000]$ & $15.16[0.000]$ & $112.11[0.000]$ \\
\hline Equality of Urban Concentration ${ }_{c}^{2000}$ (p-value) & \multicolumn{2}{|c|}{0.024} & \multicolumn{2}{|c|}{0.056} & \multicolumn{2}{|c|}{0.011} \\
\hline \multicolumn{7}{|l|}{ First-Stage Estimation } \\
\hline \multirow[t]{2}{*}{ Area Equipped for Irrigation $\mathrm{n}_{\mathrm{c}}^{1900}$} & $0.217^{* * * *}$ & $0.206^{* * *}$ & $0.217 * * * *$ & $0.197 * * *$ & $0.210^{* * * *}$ & $0.195 * * *$ \\
\hline & $(0.051)$ & $(0.065)$ & $(0.049)$ & $(0.059)$ & $(0.050)$ & $(0.061)$ \\
\hline First-Stage F Statistic on Excluded IV [p-value] & $17.96[0.000]$ & $10.07[0.003]$ & $19.36[0.000]$ & $11.21[0.002]$ & $17.37[0.000]$ & $10.31[0.003]$ \\
\hline
\end{tabular}

Notes: $* p<0.1 ; * * p<0.05 ; * * * p<0.01 ; * * * * p<0.001$. TSLS estimates. Robust standard errors are reported in parentheses. All specifications include a constant term. (d) denotes a binary variable. Low- and high-income countries are classified according the World Bank Group's taxonomy. The test of equal urban concentration coefficients for low- vs. high-income countries is obtained through bootstrapping (1,000 replications). Table A2 (Online Appendix A) reports the definition of the variables. The full set of first-stage estimates is available upon request. 
Table B6: The economic returns of urban concentration for low- vs. high-density urban areas within

FUAs.

\begin{tabular}{|c|c|c|c|c|c|c|}
\hline Dependent Variable & 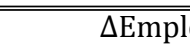 & jment ${ }_{\mathrm{c}}$ & 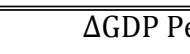 & - Capita & $\Delta \overline{\Delta \text { Labour P }}$ & oductivity \\
\hline Low- vs. High-Density Urban Areas in FUAs & Low-Density & High-Density & Low-Density & High-Density & Low-Density & High-Density \\
\hline & (1) & (2) & (3) & (4) & (5) & (6) \\
\hline Urban Concentration $_{\mathrm{c}}^{2000}$ (low-density) & $\begin{array}{c}-0.027 * * \\
(0.012)\end{array}$ & $\cdots$ & $\begin{array}{c}0.055 * * * \\
(0.017)\end{array}$ & $\ldots$ & $\begin{array}{c}0.078^{* * * *} \\
(0.018)\end{array}$ & $\cdots$ \\
\hline Urban Concentration $_{\mathrm{c}}^{2000}$ (high-density) & $\ldots$ & $\begin{array}{c}-0.030 * * \\
(0.013)\end{array}$ & $\cdots$ & $\begin{array}{c}0.061^{* * *} \\
(0.020)\end{array}$ & $\cdots$ & $\begin{array}{c}0.086^{* * * *} \\
(0.021)\end{array}$ \\
\hline $\log \left(\right.$ Employment $\left._{\mathrm{c}}^{2000}\right)$ & $\begin{array}{c}-0.005^{* * *} \\
(0.002)\end{array}$ & $\begin{array}{c}-0.006^{* * *} \\
(0.002)\end{array}$ & $\cdots$ & $\cdots$ & $\ldots$ & $\ldots$ \\
\hline $\log \left(\right.$ GDP Per Capita $\left.{ }_{c}^{2000}\right)$ & $\ldots$ & $\ldots$ & $\begin{array}{c}-0.018^{* * * *} \\
(0.003)\end{array}$ & $\begin{array}{c}-0.019^{* * * *} \\
(0.003)\end{array}$ & $\cdots$ & $\cdots$ \\
\hline $\log \left(\right.$ Labour Productivity $\left.{ }_{c}^{2000}\right)$ & $\ldots$ & $\ldots$ & $\ldots$ & $\ldots$ & $\begin{array}{c}-0.018^{* * * *} \\
(0.003)\end{array}$ & $\begin{array}{c}-0.018 * * * * \\
(0.003)\end{array}$ \\
\hline $\log \left(\right.$ Employment $_{\mathrm{c}}^{\text {Avg. } 1991 \text { to } 2000)}$ & $\ldots$ & $\ldots$ & $\begin{array}{c}0.009^{* * * *} \\
(0.003)\end{array}$ & $\begin{array}{c}0.010^{* * * *} \\
(0.003)\end{array}$ & $\begin{array}{c}0.011^{* * * *} \\
(0.003)\end{array}$ & $\begin{array}{c}0.013 * * * * \\
(0.003)\end{array}$ \\
\hline $\log \left(\right.$ GDP Per Capita ${ }_{c}^{\text {Avg. }} 1990$ to 2000 ) & $\begin{array}{c}0.001 \\
(0.002)\end{array}$ & $\begin{array}{c}0.001 \\
(0.002)\end{array}$ & $\ldots$ & $\ldots$ & $\ldots$ & $\ldots$ \\
\hline Gross Fixed Capital Formation to GDPAvg. 1990 to 2000 & $\begin{array}{l}-0.012 \\
(0.026)\end{array}$ & $\begin{array}{l}-0.009 \\
(0.026)\end{array}$ & $\begin{array}{l}0.033 \\
(0.035)\end{array}$ & $\begin{array}{l}0.025 \\
(0.037)\end{array}$ & $\begin{array}{c}0.026 \\
(0.039)\end{array}$ & $\begin{array}{l}0.016 \\
(0.041)\end{array}$ \\
\hline 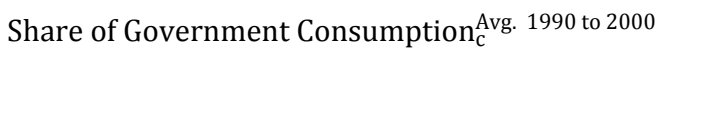 & $\begin{array}{l}-0.003 \\
(0.015)\end{array}$ & $\begin{array}{l}-0.008 \\
(0.016)\end{array}$ & $\begin{array}{l}-0.028 \\
(0.025)\end{array}$ & $\begin{array}{l}-0.018 \\
(0.027)\end{array}$ & $\begin{array}{l}-0.032 \\
(0.024)\end{array}$ & $\begin{array}{l}-0.018 \\
(0.027)\end{array}$ \\
\hline Oil Rent to GDP Avg. 1990 to 2000 & $\begin{array}{c}0.050 * * * \\
(0.018)\end{array}$ & $\begin{array}{l}0.027 * \\
(0.016)\end{array}$ & $\begin{array}{l}-0.022 \\
(0.025)\end{array}$ & $\begin{array}{l}0.025 \\
(0.026)\end{array}$ & $\begin{array}{l}-0.045^{*} \\
(0.026)\end{array}$ & $\begin{array}{c}0.020 \\
(0.027)\end{array}$ \\
\hline Openess Avg. $_{\mathrm{C}} 1990$ to 2000 & $\begin{array}{l}0.010^{*} \\
(0.005)\end{array}$ & $\begin{array}{l}0.010 * * \\
(0.005)\end{array}$ & $\begin{array}{c}0.015^{* * * *} \\
(0.005)\end{array}$ & $\begin{array}{c}0.014 * * * \\
(0.005)\end{array}$ & $\begin{array}{l}0.011^{*} \\
(0.006)\end{array}$ & $\begin{array}{c}0.010 \\
(0.006)\end{array}$ \\
\hline Share of High Tech Export ${ }_{c}^{\text {Avg. }} 1990$ to 2000 & $\begin{array}{c}0.003 \\
(0.009)\end{array}$ & $\begin{array}{l}0.006 \\
(0.010)\end{array}$ & $\begin{array}{l}-0.016 \\
(0.012)\end{array}$ & $\begin{array}{l}-0.022 * \\
(0.012)\end{array}$ & $\begin{array}{l}-0.007 \\
(0.015)\end{array}$ & $\begin{array}{l}-0.014 \\
(0.016)\end{array}$ \\
\hline High Income $_{c}(\mathrm{~d})$ & $\begin{array}{l}-0.002 \\
(0.003)\end{array}$ & $\begin{array}{l}-0.003 \\
(0.003)\end{array}$ & $\begin{array}{c}0.015 * * * \\
(0.005)\end{array}$ & $\begin{array}{c}0.017 * * * \\
(0.005)\end{array}$ & $\begin{array}{l}0.011 * * \\
(0.005)\end{array}$ & $\begin{array}{l}0.014 * * \\
(0.006)\end{array}$ \\
\hline
\end{tabular}




\begin{tabular}{|c|c|c|c|c|c|c|}
\hline \multirow[t]{2}{*}{ Population Density Avg. 1990 to 2000} & 0.000 & 0.000 & 0.000 & 0.000 & -0.000 & -0.000 \\
\hline & $(0.000)$ & $(0.000)$ & $(0.000)$ & $(0.000)$ & $(0.000)$ & $(0.000)$ \\
\hline \multirow[t]{2}{*}{ Years of Schooling Avg. 1990, 1995, 2000} & $-0.002 * *$ & $-0.002 * *$ & $0.003 * * * *$ & $0.004 * * *$ & $0.004 * * *$ & $0.004 * * *$ \\
\hline & $(0.001)$ & $(0.001)$ & $(0.001)$ & $(0.001)$ & $(0.001)$ & $(0.001)$ \\
\hline \multirow[t]{2}{*}{ 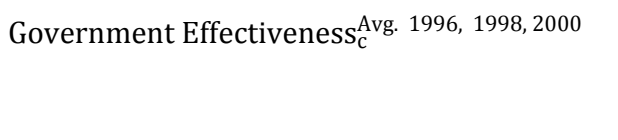 } & 0.001 & 0.002 & 0.004 & 0.003 & 0.003 & 0.001 \\
\hline & $(0.002)$ & $(0.002)$ & $(0.003)$ & $(0.003)$ & $(0.003)$ & $(0.003)$ \\
\hline \multirow[t]{2}{*}{$\log \left(\right.$ Surface $\left._{c}\right)$} & 0.002 & $0.002 * *$ & 0.003 & 0.002 & 0.003 & 0.002 \\
\hline & $(0.001)$ & $(0.001)$ & $(0.002)$ & $(0.002)$ & $(0.002)$ & $(0.002)$ \\
\hline \multirow[t]{2}{*}{$\operatorname{Island}_{c}(\mathrm{~d})$} & -0.002 & 0.000 & 0.004 & -0.001 & 0.006 & -0.001 \\
\hline & $(0.003)$ & $(0.003)$ & $(0.004)$ & $(0.005)$ & $(0.005)$ & $(0.005)$ \\
\hline \multirow[t]{2}{*}{ Landlocked ${ }_{c}(\mathrm{~d})$} & 0.004 & 0.003 & -0.005 & -0.003 & $-0.008^{*}$ & -0.006 \\
\hline & $(0.002)$ & $(0.002)$ & $(0.004)$ & $(0.004)$ & $(0.005)$ & $(0.005)$ \\
\hline \multirow[t]{2}{*}{ Latitude $_{c}$} & -0.000 & -0.000 & $0.000 * *$ & 0.000 & $0.000^{*}$ & 0.000 \\
\hline & $(0.000)$ & $(0.000)$ & $(0.000)$ & $(0.000)$ & $(0.000)$ & $(0.000)$ \\
\hline \multirow[t]{2}{*}{ Longitude $_{c}$} & -0.000 & -0.000 & -0.000 & $-0.000 *$ & $-0.000 * *$ & $-0.000 * * *$ \\
\hline & $(0.000)$ & $(0.000)$ & $(0.000)$ & $(0.000)$ & $(0.000)$ & $(0.000)$ \\
\hline Macro-Region Dummies & Yes & Yes & Yes & Yes & Yes & Yes \\
\hline Number of Countries & 108 & 108 & 108 & 108 & 108 & 108 \\
\hline $\mathrm{R}^{2}$ & 0.60 & 0.62 & 0.56 & 0.48 & 0.43 & 0.37 \\
\hline Model F Statistic [p-value] & $14.08[0.000]$ & $15.69[0.000]$ & $11.78[0.000]$ & $13.21[0.000]$ & $13.39[0.000]$ & $15.90[0.000]$ \\
\hline \multirow[t]{2}{*}{ Equality of Low- vs. High-Density (p-value) } & \multicolumn{2}{|c|}{0.039} & \multicolumn{2}{|c|}{0.027} & \multicolumn{2}{|c|}{0.041} \\
\hline & & & & & & \\
\hline \multirow[t]{2}{*}{ Area Equipped for Irrigation ${ }_{c}^{1900}$} & $0.219 * * * *$ & $0.196^{* * * *}$ & $0.220 * * * *$ & $0.199 * * * *$ & $0.219 * * * *$ & $0.198 * * * *$ \\
\hline & $(0.041)$ & $(0.043)$ & $(0.038)$ & $(0.040)$ & $(0.041)$ & $(0.045)$ \\
\hline First-Stage F Statistic on Excluded IV [p-value] & $27.89[0.000]$ & $20.42[0.000]$ & $33.63[0.000]$ & $24.30[0.000]$ & $28.13[0.000]$ & $19.65[0.000]$ \\
\hline
\end{tabular}

\footnotetext{
Notes: $* p<0.1 ; * * p<0.05 ; * * * p<0.01 ; * * * * p<0.001$. TSLS estimates. Robust standard errors are reported in parentheses. All specifications include a constant term. (d) denotes a binary variable. Low- and high-density urban areas within FUAs are defined as in the GHSL database. The test of equality between low- vs. high-density urban concentration coefficients is obtained through bootstrapping (1,000 replications). Table A2 (Online Appendix A) reports the definition of the variables. The full set of first-stage estimates is available upon request.
} 
Table B7: The economic returns of urban concentration by FUAs' population threshold values.

\begin{tabular}{|c|c|c|c|c|c|}
\hline Dependent Variable & & & Employmen & & \\
\hline FUAs' Population Threshold Values & $\geq 50,000$ & $\geq 100,000$ & $\geq 150,000$ & $\geq 200,000$ & $\geq 250,00$ \\
\hline & (1) & (2) & (3) & (4) & (5) \\
\hline Urban Concentration $_{\mathrm{c}}^{2000}(\geq 50,000)$ & $\begin{array}{c}-0.033^{* *} \\
(0.014)\end{array}$ & $\ldots$ & $\cdots$ & $\ldots$ & $\ldots$ \\
\hline Urban Concentration $_{\mathrm{c}}^{2000}(\geq 100,000)$ & $\cdots$ & $\begin{array}{c}-0.031 * * \\
(0.013)\end{array}$ & $\ldots$ & $\ldots$ & $\ldots$ \\
\hline Urban Concentration $_{\mathrm{c}}^{2000}(\geq 150,000)$ & $\ldots$ & $\ldots$ & $\begin{array}{l}-0.024 * \\
(0.013)\end{array}$ & $\ldots$ & $\cdots$ \\
\hline Urban Concentration $_{\mathrm{c}}^{2000}(\geq 200,000)$ & $\cdots$ & $\cdots$ & $\cdots$ & $\begin{array}{l}-0.018 \\
(0.011)\end{array}$ & $\ldots$ \\
\hline Urban Concentration $_{\mathrm{c}}^{2000}(\geq 250,000)$ & $\cdots$ & $\cdots$ & $\cdots$ & .. & $\begin{array}{l}-0.016 \\
(0.011)\end{array}$ \\
\hline $\log \left(\right.$ Employment $\left._{\mathrm{c}}^{2000}\right)$ & $-0.006 * * *$ & $-0.006^{* *}$ & $-0.005 *$ & $-0.005^{*}$ & $-0.004 *$ \\
\hline & $(0.002)$ & $(0.003)$ & $(0.003)$ & $(0.002)$ & $(0.002)$ \\
\hline $\log \left(\right.$ GDP Per Capita $\left.{ }_{c}^{2000}\right)$ & $\cdots$ & $\cdots$ & $\cdots$ & $\cdots$ & $\ldots$ \\
\hline $\log \left(\right.$ Labour Productivity $\left.{ }_{c}^{2000}\right)$ & $\cdots$ & $\cdots$ & $\cdots$ & $\cdots$ & $\cdots$ \\
\hline $\log \left(\right.$ Employment ${ }_{c}^{\text {Avg. } 1991 \text { to } 2000)}$ & $\cdots$ & $\cdots$ & $\cdots$ & $\cdots$ & $\cdots$ \\
\hline $\log \left(\right.$ GDP Per Capita ${ }_{c}^{\text {Avg. }} 1990$ to 2000) & 0.002 & 0.000 & 0.001 & 0.000 & 0.001 \\
\hline & $(0.002)$ & $(0.003)$ & $(0.003)$ & $(0.002)$ & $(0.002)$ \\
\hline Gross Fixed Capital Formation to GDP Avg. 1990 to 2000 & -0.019 & -0.005 & -0.008 & -0.022 & -0.028 \\
\hline & $(0.025)$ & $(0.030)$ & $(0.030)$ & $(0.028)$ & $(0.029)$ \\
\hline 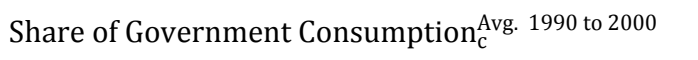 & -0.011 & -0.013 & -0.019 & -0.017 & -0.016 \\
\hline & $(0.017)$ & $(0.019)$ & $(0.018)$ & $(0.015)$ & $(0.014)$ \\
\hline Oil Rent to GDP ${ }_{\mathrm{c}}^{\text {Avg. }} 1990$ to 2000 & $0.028^{*}$ & 0.026 & 0.023 & $0.034 * *$ & $0.035^{*}$ \\
\hline & $(0.016)$ & $(0.019)$ & $(0.019)$ & $(0.017)$ & $(0.018)$ \\
\hline Openess ${ }_{c}^{\text {Avg. } 1990 ~ t o ~} 2000$ & $0.011^{* *}$ & 0.008 & 0.009 & 0.008 & 0.008 \\
\hline & $(0.005)$ & $(0.006)$ & $(0.006)$ & $(0.006)$ & $(0.006)$ \\
\hline Share of High Tech Export ${ }_{c}^{\text {Avg. }} 1990$ to 2000 & 0.009 & 0.012 & 0.010 & 0.006 & 0.007 \\
\hline
\end{tabular}




\begin{tabular}{|c|c|c|c|c|c|}
\hline & $(0.010)$ & $(0.011)$ & $(0.011)$ & $(0.010)$ & $(0.010)$ \\
\hline \multirow[t]{2}{*}{$\operatorname{High~Income~}_{c}(\mathrm{~d})$} & -0.003 & -0.001 & -0.001 & 0.000 & -0.001 \\
\hline & $(0.003)$ & $(0.004)$ & $(0.004)$ & $(0.003)$ & $(0.003)$ \\
\hline \multirow[t]{2}{*}{ Population Densityc Avg. 1990 to 2000} & 0.000 & 0.000 & 0.000 & 0.000 & 0.000 \\
\hline & $(0.000)$ & $(0.000)$ & $(0.000)$ & $(0.000)$ & $(0.000)$ \\
\hline \multirow[t]{2}{*}{ Years of Schooling Avg. 1990, 1995, 2000} & $-0.002 * *$ & $-0.002 * *$ & $-0.002 * *$ & $-0.002 * *$ & $-0.002 * *$ \\
\hline & $(0.001)$ & $(0.001)$ & $(0.001)$ & $(0.001)$ & $(0.001)$ \\
\hline \multirow[t]{2}{*}{ 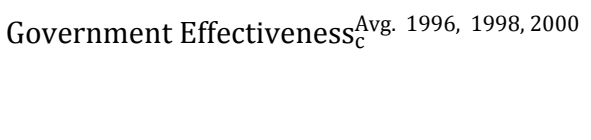 } & 0.001 & -0.000 & -0.002 & 0.001 & 0.001 \\
\hline & $(0.002)$ & $(0.003)$ & $(0.003)$ & $(0.002)$ & $(0.002)$ \\
\hline \multirow[t]{2}{*}{$\log \left(\right.$ Surface $\left._{c}\right)$} & $0.002 *$ & 0.002 & 0.001 & 0.001 & 0.001 \\
\hline & $(0.001)$ & $(0.001)$ & $(0.001)$ & $(0.001)$ & $(0.002)$ \\
\hline \multirow[t]{2}{*}{ Island $_{c}(\mathrm{~d})$} & 0.000 & 0.001 & -0.000 & 0.002 & 0.002 \\
\hline & $(0.003)$ & $(0.003)$ & $(0.003)$ & $(0.002)$ & $(0.002)$ \\
\hline \multirow[t]{2}{*}{ Landlocked $_{c}(\mathrm{~d})$} & 0.004 & $0.006^{* *}$ & $0.006^{* *}$ & $0.006^{* *}$ & $0.005^{*}$ \\
\hline & $(0.002)$ & $(0.003)$ & $(0.003)$ & $(0.002)$ & $(0.002)$ \\
\hline \multirow[t]{2}{*}{ Latitude $_{c}$} & -0.000 & -0.000 & -0.000 & -0.000 & -0.000 \\
\hline & $(0.000)$ & $(0.000)$ & $(0.000)$ & $(0.000)$ & $(0.000)$ \\
\hline \multirow[t]{2}{*}{ Longitude $_{c}$} & -0.000 & -0.000 & -0.000 & -0.000 & -0.000 \\
\hline & $(0.000)$ & $(0.000)$ & $(0.000)$ & $(0.000)$ & $(0.000)$ \\
\hline Macro-Region Dummies & Yes & Yes & Yes & Yes & Yes \\
\hline Number of Countries & 106 & 106 & 105 & 103 & 101 \\
\hline $\mathrm{R}^{2}$ & 0.62 & 0.57 & 0.60 & 0.69 & 0.69 \\
\hline Model F Statistic [p-value] & $16.36[0.000]$ & $11.83[0.000]$ & $12.80[0.000]$ & $14.53[0.000]$ & $13.67[0.000]$ \\
\hline
\end{tabular}

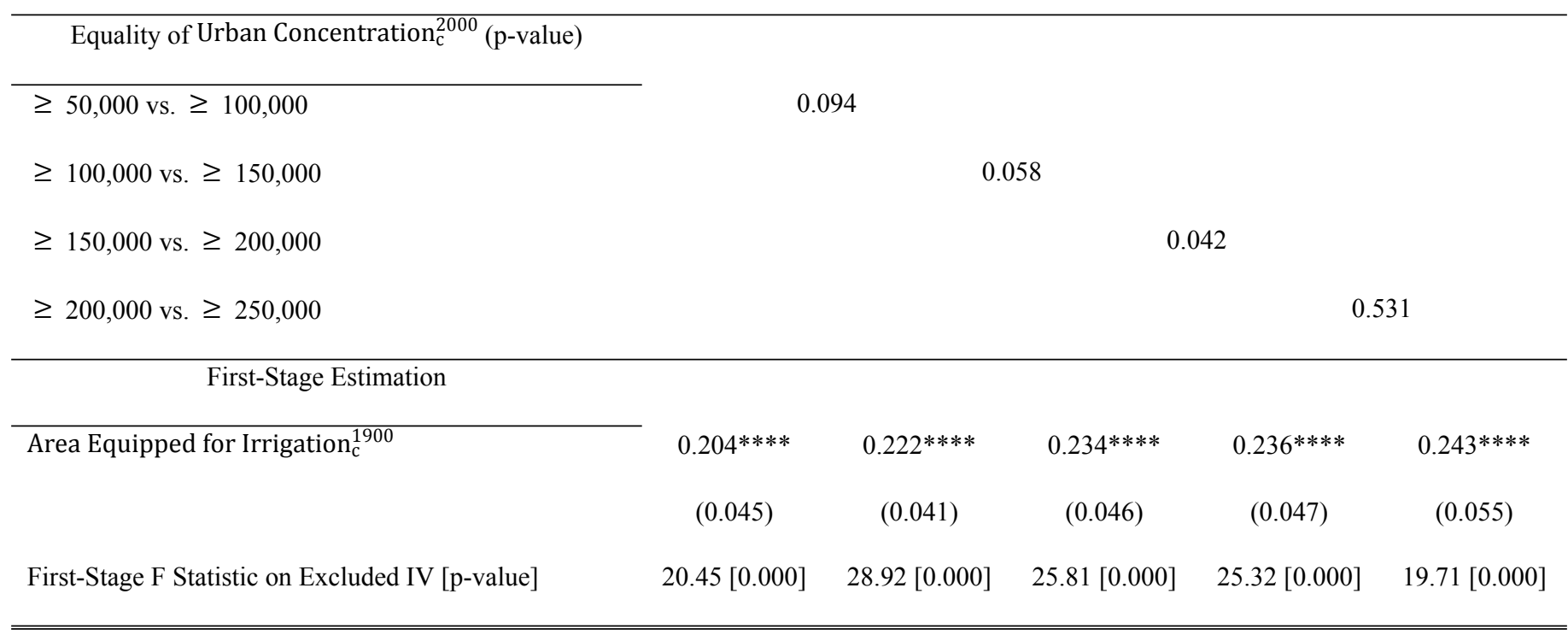


Notes: $* p<0.1 ; * * p<0.05 ; * * * p<0.01 ; * * * *<<0.001$. TSLS estimates. Robust standard errors are reported in parentheses. All specifications include a constant term. (d) denotes a binary variable. Threshold values are defined in terms of (urban and rural) population residing within a FUA. The test of equality between pairs of urban concentration coefficients is obtained through bootstrapping (1,000 replications). Table A2 (Online Appendix A) reports the definition of the variables. The full set of first-stage estimates is available upon request. 
Table B7 - Continues.

\begin{tabular}{|c|c|c|c|c|c|}
\hline \multirow{2}{*}{$\begin{array}{l}\text { Dependent Variable } \\
\text { FUAs' Population Threshold Values }\end{array}$} & \multicolumn{5}{|c|}{$\overline{\Delta \text { GDP Per Capita }_{\mathrm{c}}}$} \\
\hline & $\geq 50,000$ & $\geq 100,000$ & $\geq 150,000$ & $\geq 200,000$ & $\geq 250,000$ \\
\hline & (6) & (7) & (8) & (9) & (10) \\
\hline Urban Concentration $_{\mathrm{c}}^{2000}(\geq 50,000)$ & $\begin{array}{c}0.066^{* * * * *} \\
(0.018)\end{array}$ & $\ldots$ & $\ldots$ & $\ldots$ & $\ldots$ \\
\hline Urban Concentration $_{\mathrm{c}}^{2000}(\geq 100,000)$ & $\ldots$ & $\begin{array}{c}0.060 * * * \\
(0.019)\end{array}$ & $\ldots$ & $\ldots$ & $\cdots$ \\
\hline Urban Concentration $_{\mathrm{c}}^{2000}(\geq 150,000)$ & $\ldots$ & $\cdots$ & $\begin{array}{c}0.048 * * * \\
(0.016)\end{array}$ & $\cdots$ & $\ldots$ \\
\hline Urban Concentration $_{\mathrm{c}}^{2000}(\geq 200,000)$ & $\cdots$ & $\cdots$ & $\ldots$ & $\begin{array}{c}0.049 * * * \\
(0.017)\end{array}$ & $\cdots$ \\
\hline Urban Concentration $_{\mathrm{c}}^{2000}(\geq 250,000)$ & $\cdots$ & $\cdots$ & $\cdots$ & $\ldots$ & $\begin{array}{c}0.045^{* * *} \\
(0.016)\end{array}$ \\
\hline $\log \left(\right.$ Employment $\left._{\mathrm{c}}^{2000}\right)$ & $\cdots$ & $\cdots$ & $\ldots$ & $\cdots$ & $\ldots$ \\
\hline $\log \left(\right.$ GDP Per Capita $\left.{ }_{c}^{2000}\right)$ & $-0.019 * * * *$ & $-0.017 * * * *$ & $-0.018 * * * *$ & $-0.018 * * * *$ & $-0.018 * * * *$ \\
\hline & $(0.003)$ & $(0.003)$ & $(0.003)$ & $(0.003)$ & $(0.003)$ \\
\hline $\log \left(\right.$ Labour Productivity $\left.{ }_{c}^{2000}\right)$ & $\ldots$ & $\ldots$ & $\cdots$ & $\ldots$ & $\ldots$ \\
\hline $\log \left(\right.$ Employment $\left.{ }_{c}^{\text {Avg. } 1991 \text { to } 2000}\right)$ & $0.010 * * * *$ & $0.011^{* * * *}$ & $0.009 * * *$ & $0.009 * * *$ & $0.009 * * *$ \\
\hline & $(0.003)$ & $(0.003)$ & $(0.003)$ & $(0.003)$ & $(0.003)$ \\
\hline $\log ($ GDP Per Capita Avg. 1990 to 2000) & $\ldots$ & $\ldots$ & $\ldots$ & $\ldots$ & $\ldots$ \\
\hline Gross Fixed Capital Formation to GDP Avg. 1990 to 2000 & 0.042 & 0.011 & 0.018 & 0.010 & 0.014 \\
\hline & $(0.038)$ & $(0.040)$ & $(0.039)$ & $(0.041)$ & $(0.039)$ \\
\hline 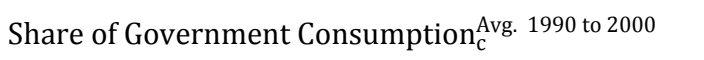 & -0.013 & -0.008 & 0.004 & -0.003 & -0.007 \\
\hline & $(0.028)$ & $(0.027)$ & $(0.027)$ & $(0.029)$ & $(0.028)$ \\
\hline Oil Rent to GDP Avg. 1990 to 2000 & 0.026 & 0.029 & 0.033 & 0.037 & 0.039 \\
\hline & $(0.027)$ & $(0.028)$ & $(0.025)$ & $(0.030)$ & $(0.030)$ \\
\hline 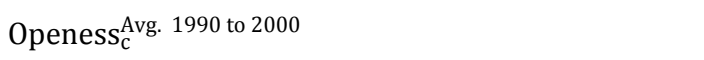 & $0.012 * *$ & $0.018^{* * *}$ & $0.016^{* * *}$ & $0.019^{* * *}$ & $0.019 * * *$ \\
\hline & $(0.005)$ & $(0.006)$ & $(0.005)$ & $(0.006)$ & $(0.006)$ \\
\hline Share of High Tech Export ${ }_{c}^{\text {Avg. }} 1990$ to 2000 & $-0.027 * *$ & $-0.031^{* *}$ & $-0.029 * *$ & $-0.030^{* *}$ & $-0.031 * *$ \\
\hline
\end{tabular}




\begin{tabular}{|c|c|c|c|c|c|}
\hline & $(0.013)$ & $(0.014)$ & $(0.012)$ & $(0.014)$ & $(0.015)$ \\
\hline \multirow[t]{2}{*}{ High Income $_{c}(\mathrm{~d})$} & $0.017 * * *$ & $0.012 * *$ & $0.014 * *$ & $0.013^{* *}$ & $0.015^{* *}$ \\
\hline & $(0.005)$ & $(0.006)$ & $(0.006)$ & $(0.007)$ & $(0.006)$ \\
\hline \multirow[t]{2}{*}{ Population Densityc Avg. 1990 to 2000} & 0.000 & 0.000 & $0.000 *$ & $0.000^{*}$ & 0.000 \\
\hline & $(0.000)$ & $(0.000)$ & $(0.000)$ & $(0.000)$ & $(0.000)$ \\
\hline \multirow[t]{2}{*}{ Years of Schooling Avg. 1990, 1995, 2000} & $0.004 * * *$ & $0.004 * * *$ & $0.003 * * *$ & $0.004 * * *$ & $0.004^{* * *}$ \\
\hline & $(0.001)$ & $(0.001)$ & $(0.001)$ & $(0.001)$ & $(0.001)$ \\
\hline \multirow[t]{2}{*}{ 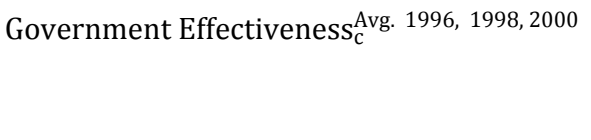 } & 0.004 & $0.006^{*}$ & $0.009 * * *$ & $0.008 * *$ & $0.007 * *$ \\
\hline & $(0.003)$ & $(0.003)$ & $(0.003)$ & $(0.004)$ & $(0.004)$ \\
\hline \multirow[t]{2}{*}{$\log \left(\right.$ Surface $\left._{c}\right)$} & 0.002 & 0.002 & $0.004 * *$ & $0.005^{* *}$ & $0.005^{*}$ \\
\hline & $(0.002)$ & $(0.002)$ & $(0.002)$ & $(0.002)$ & $(0.003)$ \\
\hline \multirow[t]{2}{*}{$\operatorname{Island}_{c}(\mathrm{~d})$} & -0.001 & -0.003 & -0.000 & -0.001 & -0.000 \\
\hline & $(0.005)$ & $(0.005)$ & $(0.006)$ & $(0.006)$ & $(0.006)$ \\
\hline \multirow[t]{2}{*}{ Landlocked $_{c}(\mathrm{~d})$} & -0.004 & $-0.009^{* *}$ & $-0.009 * *$ & $-0.009 * *$ & $-0.008^{*}$ \\
\hline & $(0.004)$ & $(0.004)$ & $(0.004)$ & $(0.004)$ & $(0.004)$ \\
\hline \multirow[t]{2}{*}{ Latitude $_{c}$} & 0.000 & $0.000^{*}$ & $0.000 * *$ & $0.000 *$ & $0.000^{*}$ \\
\hline & $(0.000)$ & $(0.000)$ & $(0.000)$ & $(0.000)$ & $(0.000)$ \\
\hline \multirow[t]{2}{*}{ Longitude $_{c}$} & -0.000 & -0.000 & -0.000 & -0.000 & -0.000 \\
\hline & $(0.000)$ & $(0.000)$ & $(0.000)$ & $(0.000)$ & $(0.000)$ \\
\hline Macro-Region Dummies & Yes & Yes & Yes & Yes & Yes \\
\hline Number of Countries & 106 & 106 & 105 & 103 & 101 \\
\hline $\mathrm{R}^{2}$ & 0.46 & 0.44 & 0.51 & 0.49 & 0.52 \\
\hline Model F Statistic [p-value] & $14.30[0.000]$ & $12.91[0.000]$ & $18.08[0.000]$ & $15.37[0.000]$ & $15.01[0.000]$ \\
\hline
\end{tabular}

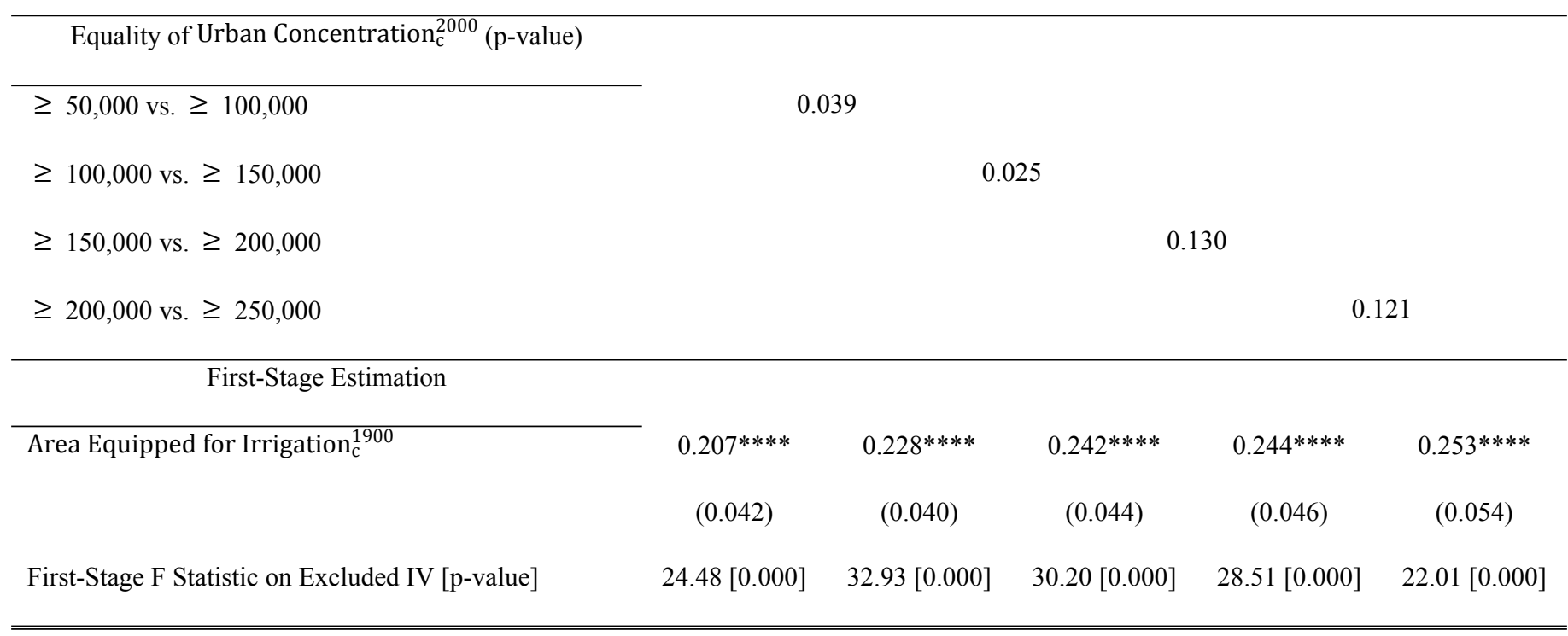




\begin{abstract}
Notes: $* p<0.1 ; * * p<0.05 ; * * * p<0.01 ; * * * * p<0.001$. TSLS estimates. Robust standard errors are reported in parentheses. All specifications include a constant term. (d) denotes a binary variable. Threshold values are defined in terms of (urban and rural) population residing within a FUA. The test of equality between pairs of urban concentration coefficients is obtained through bootstrapping (1,000 replications). Table A2 (Online Appendix A) reports the definition of the variables. The full set of first-stage estimates is available upon request.
\end{abstract}


Table B7 - Continues.

\begin{tabular}{|c|c|c|c|c|c|}
\hline Dependent Variable & & & our Producti & & \\
\hline FUAs' Population Threshold Values & $\geq 50,000$ & $\geq 100,000$ & $\geq 150,000$ & $\geq 200,000$ & $\geq 250,000$ \\
\hline & (11) & (12) & (13) & (14) & (15) \\
\hline Urban Concentration $_{\mathrm{c}}^{2000}(\geq 50,000)$ & $\begin{array}{c}0.090^{* * * *} \\
(0.020)\end{array}$ & $\cdots$ & $\cdots$ & $\cdots$ & $\cdots$ \\
\hline Urban Concentration $_{\mathrm{c}}^{2000}(\geq 100,000)$ & $\ldots$ & $\begin{array}{c}0.082 * * * * \\
(0.022)\end{array}$ & $\cdots$ & $\cdots$ & $\cdots$ \\
\hline Urban Concentration $_{\mathrm{c}}^{2000}(\geq 150,000)$ & $\cdots$ & $\ldots$ & $\begin{array}{c}0.064^{* * * *} \\
(0.018)\end{array}$ & $\cdots$ & $\cdots$ \\
\hline Urban Concentration $_{\mathrm{c}}^{2000}(\geq 200,000)$ & $\cdots$ & $\cdots$ & $\cdots$ & $\begin{array}{c}0.064^{* * * *} \\
(0.018)\end{array}$ & $\cdots$ \\
\hline Urban Concentration $_{\mathrm{c}}^{2000}(\geq 250,000)$ & $\cdots$ & $\cdots$ & $\cdots$ & $\cdots$ & $\begin{array}{c}0.061 * * * * \\
(0.018)\end{array}$ \\
\hline $\log \left(\right.$ Employment $\left._{\mathrm{c}}^{2000}\right)$ & $\cdots$ & $\cdots$ & $\cdots$ & $\cdots$ & $\cdots$ \\
\hline $\log \left(\right.$ GDP Per Capita $\left.{ }_{c}^{2000}\right)$ & $\cdots$ & $\cdots$ & $\cdots$ & $\cdots$ & $\cdots$ \\
\hline $\log \left(\right.$ Labour Productivity $\left.y_{c}^{2000}\right)$ & $-0.019 * * * *$ & $-0.016^{* * * *}$ & $-0.018 * * * *$ & $-0.017 * * * *$ & $-0.018 * * * *$ \\
\hline & $(0.003)$ & $(0.004)$ & $(0.004)$ & $(0.003)$ & $(0.003)$ \\
\hline $\log \left(\right.$ Employment $\left._{\mathrm{c}}^{\text {Avg. } 1991 \text { to } 2000}\right)$ & $0.013^{* * * *}$ & $0.015^{* * * *}$ & $0.011 * * *$ & $0.012 * * *$ & $0.012 * * *$ \\
\hline & $(0.003)$ & $(0.004)$ & $(0.004)$ & $(0.004)$ & $(0.004)$ \\
\hline $\log \left(\right.$ GDP Per Capita ${ }_{c}^{\text {Avg. }} 1990$ to 2000) & $\cdots$ & $\cdots$ & $\cdots$ & $\cdots$ & $\cdots$ \\
\hline Gross Fixed Capital Formation to $\mathrm{GDP}_{\mathrm{c}}^{\text {Avg. }} 1990$ to 2000 & 0.037 & -0.006 & 0.006 & 0.002 & 0.012 \\
\hline & $(0.041)$ & $(0.045)$ & $(0.043)$ & $(0.046)$ & $(0.047)$ \\
\hline 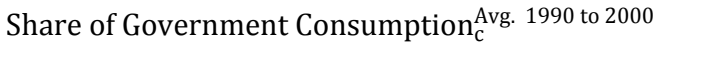 & -0.012 & -0.008 & 0.007 & -0.002 & -0.006 \\
\hline & $(0.028)$ & $(0.029)$ & $(0.027)$ & $(0.029)$ & $(0.029)$ \\
\hline Oil Rent to $\mathrm{GDP}_{\mathrm{c}}^{\text {Avg. }} 1990$ to 2000 & 0.019 & 0.026 & 0.032 & 0.032 & 0.030 \\
\hline & $(0.029)$ & $(0.028)$ & $(0.026)$ & $(0.030)$ & $(0.032)$ \\
\hline Openess $\mathrm{c}_{\mathrm{C}}^{\text {Avg. } 1990 \text { to } 2000}$ & 0.008 & $0.016^{* *}$ & $0.013 * *$ & $0.017 * *$ & $0.018 * *$ \\
\hline & $(0.006)$ & $(0.007)$ & $(0.006)$ & $(0.007)$ & $(0.007)$ \\
\hline Share of High Tech Export Avg. 1990 to 2000 & -0.020 & -0.027 & -0.023 & -0.024 & -0.027 \\
\hline
\end{tabular}




\begin{tabular}{|c|c|c|c|c|c|}
\hline & $(0.016)$ & $(0.017)$ & $(0.014)$ & $(0.016)$ & $(0.017)$ \\
\hline \multirow[t]{2}{*}{ High Income $_{c}$ (d) } & $0.014 * *$ & 0.007 & 0.010 & 0.008 & $0.011^{*}$ \\
\hline & $(0.006)$ & $(0.007)$ & $(0.007)$ & $(0.007)$ & $(0.007)$ \\
\hline \multirow[t]{2}{*}{ Population Density Avg. 1990 to 2000} & -0.000 & -0.000 & 0.000 & 0.000 & 0.000 \\
\hline & $(0.000)$ & $(0.000)$ & $(0.000)$ & $(0.000)$ & $(0.000)$ \\
\hline \multirow[t]{2}{*}{ Years of Schooling Avg. 1990, 1995, 2000} & $0.004 * * *$ & $0.004 * * *$ & $0.004 * * *$ & $0.005^{* * *}$ & $0.005^{* * *}$ \\
\hline & $(0.001)$ & $(0.001)$ & $(0.001)$ & $(0.002)$ & $(0.002)$ \\
\hline \multirow[t]{2}{*}{ 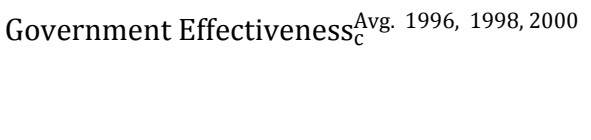 } & 0.003 & 0.006 & $0.010 * * *$ & $0.008 * *$ & $0.007 *$ \\
\hline & $(0.003)$ & $(0.004)$ & $(0.004)$ & $(0.004)$ & $(0.004)$ \\
\hline \multirow[t]{2}{*}{$\log \left(\right.$ Surface $\left._{c}\right)$} & 0.002 & 0.003 & $0.005^{* *}$ & $0.006^{* *}$ & $0.006^{* *}$ \\
\hline & $(0.003)$ & $(0.002)$ & $(0.002)$ & $(0.002)$ & $(0.003)$ \\
\hline \multirow[t]{2}{*}{$\operatorname{Island}_{c}(\mathrm{~d})$} & -0.001 & -0.004 & 0.000 & -0.002 & -0.000 \\
\hline & $(0.006)$ & $(0.006)$ & $(0.006)$ & $(0.006)$ & $(0.006)$ \\
\hline \multirow[t]{2}{*}{ Landlocked $_{c}(\mathrm{~d})$} & -0.008 & $-0.014 * * *$ & $-0.013 * * *$ & $-0.014 * * *$ & $-0.012 * *$ \\
\hline & $(0.005)$ & $(0.005)$ & $(0.005)$ & $(0.005)$ & $(0.005)$ \\
\hline \multirow[t]{2}{*}{ Latitude $_{c}$} & 0.000 & $0.000^{*}$ & $0.000 * *$ & $0.000^{*}$ & 0.000 \\
\hline & $(0.000)$ & $(0.000)$ & $(0.000)$ & $(0.000)$ & $(0.000)$ \\
\hline \multirow[t]{2}{*}{ Longitude $_{c}$} & $-0.000 * *$ & $-0.000^{*}$ & $-0.000 * *$ & $-0.000 * *$ & $-0.000 * * *$ \\
\hline & $(0.000)$ & $(0.000)$ & $(0.000)$ & $(0.000)$ & $(0.000)$ \\
\hline Macro-Region Dummies & Yes & Yes & Yes & Yes & Yes \\
\hline Number of Countries & 106 & 106 & 105 & 103 & 101 \\
\hline $\mathrm{R}^{2}$ & 0.31 & 0.26 & 0.38 & 0.39 & 0.42 \\
\hline Model F Statistic [p-value] & $23.97[0.000]$ & $13.37[0.000]$ & $18.09[0.000]$ & $16.31[0.000]$ & $18.14[0.000]$ \\
\hline
\end{tabular}

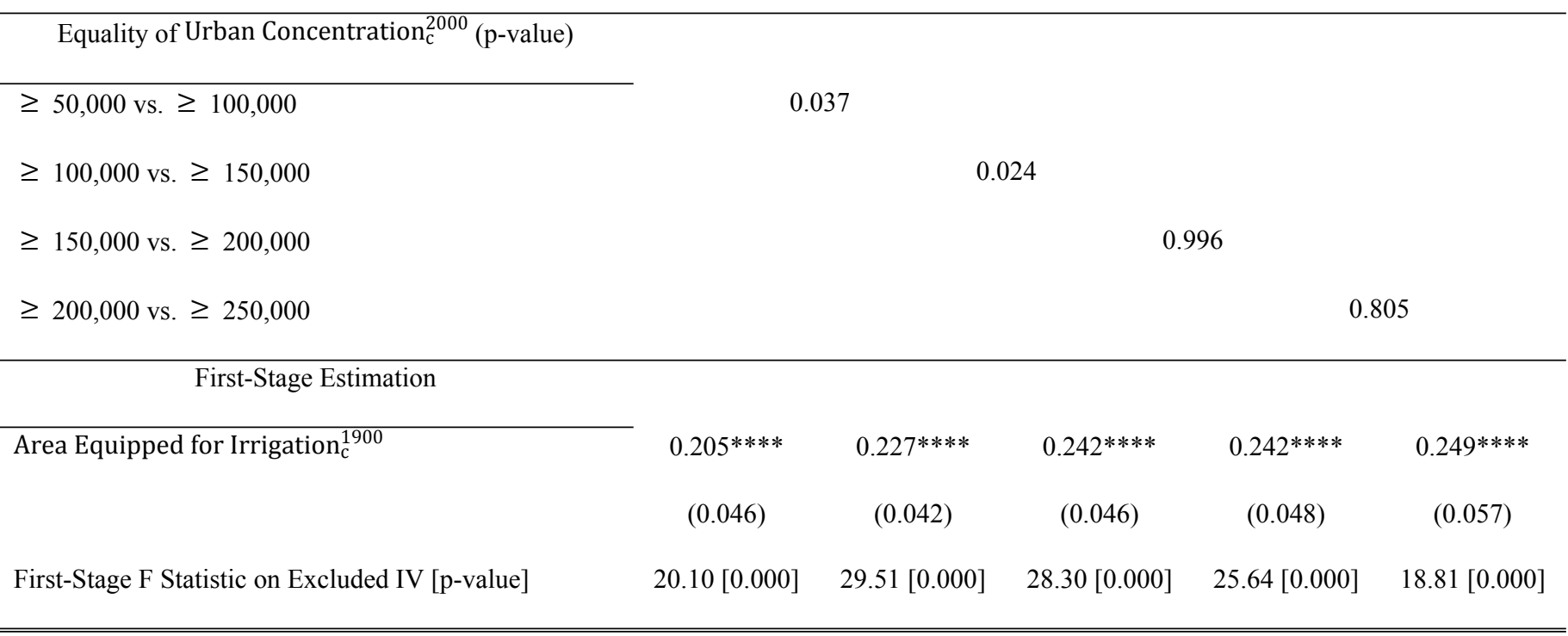


Notes: $* p<0.1 ; * * p<0.05 ; * * * p<0.01 ; * * * *<0.001$. TSLS estimates. Robust standard errors are reported in parentheses. All specifications include a constant term. (d) denotes a binary variable. Threshold values are defined in terms of (urban and rural) population residing within a FUA. The test of equality between pairs of urban concentration coefficients is obtained through bootstrapping (1,000 replications). Table A2 (Online Appendix A) reports the definition of the variables. The full set of first-stage estimates is available upon request. 


\section{ONLINE APPENDIX C - Robustness exercises}

A series of exercises has been performed, first, to check the robustness of the Ordinary Least Squares (OLS) and Two-Stage Least Squares (TSLS) results presented in Table 1 (Manuscript) in terms of model specification.

First, we have removed the initial growth employment variable - i.e., log $\left(\right.$ Employment $\left._{c}^{2000}\right)$ - from the employment growth equation, and the employment variable averaged over the period

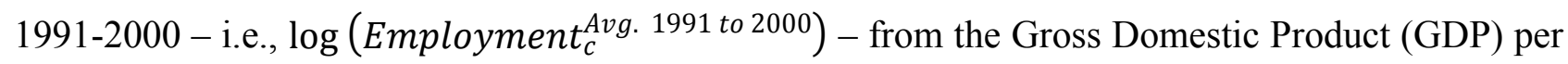
capita and labour productivity growth equation, because of their high collinearity with the urban concentration variable $-\rho=-0.759$ and $\rho=-0.760$, respectively. The results of this exercise are reported in Table $\mathrm{C} 1$ and fully confirm the main findings.

Second, we have tested the robustness of the OLS and TSLS results presented in Table 1 (Manuscript) by including simultaneously the initial growth variables for employment $\log \left(\right.$ Employment $\left._{c}^{2000}\right)$-, GDP per capita - log (GDP Per Capita $\left.{ }_{c}^{2000}\right)$ - and labour productivity $\log ($ Labour Productivity 2000$)$ - in the employment, GDP per capita, and labour productivity growth equations. ${ }^{2}$ The results of this exercise are reported in Table C2. They fully confirm the main findings.

Third, we have considered the minimum, mean, and maximum values of a country's latitude and longitude geographic coordinates rather than the coordinates of the centroid. The rationale of this exercise is that the coordinates of the centroid would potentially be too restrictive to control for geographic heterogeneity in the case of very large countries. The results of this exercise are reported in Table C3. They also confirm the main findings.

\footnotetext{
${ }^{2}$ The GDP per capita variable averaged over the period 1990-2000 - i.e., log (GDP Per Capita Avg. 1990 to 2000) - has not been included in the employment growth equation, while the employment variable averaged over the period 1991-2000

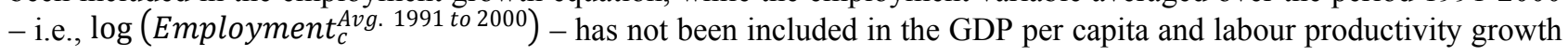
equations.
} 
Fourth, we have included an additional control variable capturing the log-number of Functional Urban Areas (FUA) within a country. The results of this exercise, that are reported in Table C4, fully confirm the main ones.

Fifth, we have added as additional control a variable capturing the overall percentage of urban population within a country according to official country statistics provided by the World Bank Group. The results are reported in Table C5, and, once again, confirm the main findings.

A second series of tests has been performed to check the robustness of the TSLS estimation of Equation (1) in the Manuscript, and, particularly, our identification strategy based on the external instrumental variable (IV) capturing the irrigated land area in 1900.

First, we consider only the control variables which turned out to be statistically significant in the baseline model with respect to each of the three economic dimensions considered - employment, GDP per capita, and labour productivity growth. The results of this exercise are reported in Table C6. They fully confirm those reported in Table 1 (Manuscript).

Second, we have replicated the baseline TSLS estimation of Equation (1) adding a control variable capturing the GDP per capita value in the year 1900 as a proxy for past economic development, in order to assess the sensitivity of our IV capturing land area equipped for irrigation in the year 1900. In fact, our IV would be problematic if development in irrigation infrastructures was related to the level of economic development of a country. The idea of this robustness exercise is that the inclusion of a proxy for economic development referring to the same year of measurement as our IV would exclude any biases related to persistence in countries' economic development. The historical GDP data series was obtained from Geiger and Frieler (2018), who provide a globallyharmonised dataset on historical - and projected - GDP (per capita) data. The results of this exercise, reported in Table C7, confirm both the predictive power of our IV and our main findings.

Third, the TSLS estimation of Equation (1) has been replicated by specifying an over-identified equation that adds a second external IV to that capturing irrigated land area in 1900. In the spirit of Frick and Rodríguez-Pose (2018), the second IV captures country-level terrain ruggedness as first- 
nature characteristic, under the rationale that a high level of terrain ruggedness could lead to a low degree of urban concentration by influencing land suitability for building cities and trade possibilities among places (Nunn and Puga, 2012). As shown in Table C8, the first-stage coefficients for terrain ruggedness are negligible, despite showing the expected negative sign. However, the first-stage F statistics on the excluded IVs are higher than the conservative cut-off value of 10 , and the null hypothesis of instruments' validity is never rejected as pointed out by the p-values of the Hansen's (1982) J statistic. In addition, the main results are fully confirmed, also when controlling for past economic development captured by GDP per capita in 1900.

Fourth, a second over-identified equation has been specified by adding as second IV the percentage of a country's urban land in the year 1881, besides that capturing land area equipped for irrigation in 1900. The variable for urban land in 1881 is defined using historical reconstructed landcover data derived from the Historical Database of the Global Environment (HYDE 3.1), that provides grid cells of $0.5^{\circ}$ width, each containing land-cover yearly observations for the period 1770 2010 - see Goldewijk et al. (2010) and Goldewijk et al. (2011) for details. The rationale of this second IV - defined as the country-specific average of land defined as 'urban' in 1881 - is that countries that were highly 'urbanised' in the past could have been more likely to be characterised by a subsequent low degree of urban concentration, as long as urban settlements were already spread over the surface of a country in the past. The exogeneity of this IV is strengthened by the fact that it is defined about one century before our economic growth variables. As shown in Table C9, the IV for urban land in 1881 shows the expected negative first-stage coefficients, and also appears to be a valuable predictor for the current degree of urban concentration. Moreover, the first-stage F statistics on the excluded IVs are higher than the conservative cut-off value of 10, and the null hypothesis of instruments' validity is never rejected as pointed out by the p-values of the Hansen's (1982) J statistic. In addition, the main results are fully confirmed, also when controlling for past economic development captured by GDP per capita in 1900 . 
Fifth, the robustness of the baseline TSLS specification has been tested by removing from the computation of the urban concentration variable those FUAs lying in the top and bottom 5\% and 10\% of the distribution of FUAs' population. Therefore, this test trims extremely large and small FUAs, that can be considered as potential outliers. The results are reported in Table C10 and fully confirm the main findings reported in Table 1 (Manuscript).

Finally, the TSLS estimation of Equation (1) has been replicated on a reduced sample of 102 countries that present at least two FUAs in the Global Human Settlement Layer (GHSL) database. Thus, this exercise removes those countries characterised by the maximum value of the urban concentration index by construction, even though the fact that they are characterised by a unique FUA should not be considered as a cause of potential bias, it being their specific urban structure. The results of this exercise are reported in Table C11 and fully confirm those reported in Table 1 (Manuscript). 
Table C1: The economic returns of urban concentration - Robustness test removing collinear employment variables.

\begin{tabular}{|c|c|c|c|c|c|c|}
\hline \multirow{2}{*}{$\begin{array}{l}\text { Dependent Variable } \\
\text { Estimation Method }\end{array}$} & \multicolumn{2}{|c|}{$\bar{~} \Delta$ Employment $_{\mathrm{c}}$} & \multicolumn{2}{|c|}{ 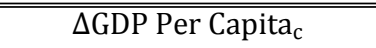 } & \multicolumn{2}{|c|}{ 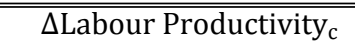 } \\
\hline & OLS & TSLS & OLS & TSLS & OLS & TSLS \\
\hline \multirow{3}{*}{ Urban Concentration $_{\mathrm{c}}^{2000}$} & (1) & (2) & (3) & (4) & (5) & (6) \\
\hline & -0.003 & $-0.005^{* * *}$ & $0.015^{*}$ & $0.009 * * * *$ & $0.014 *$ & $0.012 * * * *$ \\
\hline & $(0.005)$ & $(0.001)$ & $(0.008)$ & $(0.003)$ & $(0.008)$ & $(0.003)$ \\
\hline \multirow[t]{2}{*}{$\log \left(\right.$ GDP Per Capita $\left.{ }_{c}^{2000}\right)$} & $\cdots$ & $\cdots$ & $-0.016^{* * * *}$ & $-0.011 * * * *$ & $\ldots$ & $\ldots$ \\
\hline & & & $(0.003)$ & $(0.003)$ & & \\
\hline \multirow[t]{2}{*}{$\log \left(\right.$ Labour Productivity $\left.{ }_{c}^{2000}\right)$} & $\cdots$ & $\cdots$ & $\cdots$ & $\cdots$ & $-0.016^{* * * *}$ & $-0.009 * * *$ \\
\hline & & & & & $(0.003)$ & $(0.003)$ \\
\hline \multirow[t]{2}{*}{$\log \left(\right.$ GDP Per Capita ${ }_{c}^{\text {Avg. } 1990 ~ t o ~ 2000) ~}$} & 0.000 & -0.002 & $\ldots$ & $\ldots$ & $\cdots$ & $\cdots$ \\
\hline & $(0.002)$ & $(0.002)$ & & & & \\
\hline \multirow[t]{2}{*}{ Gross Fixed Capital Formation to GDP Avg. 1990 to 2000} & -0.027 & -0.020 & 0.031 & 0.035 & $0.048^{*}$ & 0.020 \\
\hline & $(0.024)$ & $(0.026)$ & $(0.028)$ & $(0.028)$ & $(0.028)$ & $(0.029)$ \\
\hline \multirow[t]{2}{*}{ 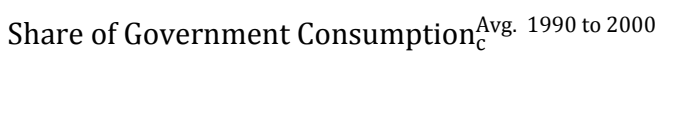 } & -0.008 & -0.013 & -0.008 & 0.002 & -0.012 & 0.005 \\
\hline & $(0.014)$ & $(0.016)$ & $(0.023)$ & $(0.027)$ & $(0.020)$ & $(0.028)$ \\
\hline \multirow[t]{2}{*}{ Oil Rent to GDP Avg. 1990 to 2000} & $0.050 * * *$ & $0.045^{* *}$ & -0.005 & -0.013 & $-0.034 *$ & -0.025 \\
\hline & $(0.017)$ & $(0.019)$ & $(0.020)$ & $(0.021)$ & $(0.019)$ & $(0.025)$ \\
\hline \multirow[t]{2}{*}{ Openess Avg. $_{\mathrm{C}} 1990$ to 2000} & $0.013 * * *$ & $0.011 * *$ & $0.013 * *$ & $0.014 * *$ & 0.004 & $0.011^{*}$ \\
\hline & $(0.004)$ & $(0.004)$ & $(0.005)$ & $(0.006)$ & $(0.005)$ & $(0.006)$ \\
\hline \multirow[t]{2}{*}{ Share of High Tech Export ${ }_{c}^{\text {Avg. }} 1990$ to 2000} & -0.001 & -0.006 & -0.015 & -0.000 & 0.001 & 0.014 \\
\hline & $(0.008)$ & $(0.009)$ & $(0.010)$ & $(0.013)$ & $(0.010)$ & $(0.016)$ \\
\hline \multirow[t]{2}{*}{ High Income $_{c}(d)$} & -0.001 & 0.002 & $0.015 * * *$ & 0.008 & $0.011 * *$ & 0.003 \\
\hline & $(0.003)$ & $(0.003)$ & $(0.005)$ & $(0.005)$ & $(0.005)$ & $(0.006)$ \\
\hline \multirow[t]{2}{*}{ Population Density Avg. 1990 to 2000} & 0.000 & 0.000 & 0.000 & 0.000 & 0.000 & 0.000 \\
\hline & $(0.000)$ & $(0.000)$ & $(0.000)$ & $(0.000)$ & $(0.000)$ & $(0.000)$ \\
\hline \multirow[t]{2}{*}{ Years of Schooling Avg. 1990, 1995, 2000} & -0.001 & $-0.002 *$ & $0.003^{* * *}$ & $0.003 * * *$ & $0.003^{* * *}$ & $0.004^{* * *}$ \\
\hline & $(0.001)$ & $(0.001)$ & $(0.001)$ & $(0.001)$ & $(0.001)$ & $(0.001)$ \\
\hline \multirow[t]{2}{*}{ 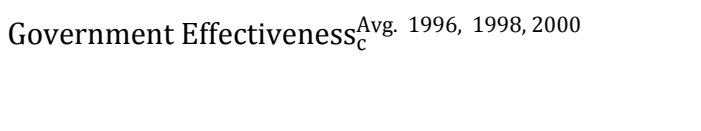 } & 0.001 & 0.002 & 0.003 & 0.001 & 0.002 & 0.000 \\
\hline & $(0.002)$ & $(0.002)$ & $(0.003)$ & $(0.003)$ & $(0.003)$ & $(0.004)$ \\
\hline
\end{tabular}




\begin{tabular}{|c|c|c|c|c|c|c|}
\hline \multirow[t]{2}{*}{$\log \left(\right.$ Surface $\left._{c}\right)$} & 0.001 & $0.002^{* *}$ & $0.005^{* * * *}$ & 0.001 & $0.004 * * *$ & 0.001 \\
\hline & $(0.001)$ & $(0.001)$ & $(0.002)$ & $(0.001)$ & $(0.001)$ & $(0.002)$ \\
\hline \multirow[t]{2}{*}{$\operatorname{Island}_{\mathrm{c}}(\mathrm{d})$} & -0.001 & -0.001 & -0.000 & -0.000 & 0.001 & 0.000 \\
\hline & $(0.003)$ & $(0.002)$ & $(0.005)$ & $(0.005)$ & $(0.005)$ & $(0.006)$ \\
\hline \multirow[t]{2}{*}{ Landlocked $_{c}(\mathrm{~d})$} & $0.004^{*}$ & $0.006^{* *}$ & -0.003 & $-0.008 * *$ & $-0.008 * *$ & $-0.012 * * *$ \\
\hline & $(0.002)$ & $(0.002)$ & $(0.003)$ & $(0.004)$ & $(0.003)$ & $(0.004)$ \\
\hline \multirow{2}{*}{ Latitude $_{c}$} & -0.000 & -0.000 & 0.000 & 0.000 & 0.000 & 0.000 \\
\hline & $(0.000)$ & $(0.000)$ & $(0.000)$ & $(0.000)$ & $(0.000)$ & $(0.000)$ \\
\hline \multirow[t]{2}{*}{ Longitude $_{c}$} & $-0.000 * *$ & $-0.000 * *$ & 0.000 & -0.000 & -0.000 & -0.000 \\
\hline & $(0.000)$ & $(0.000)$ & $(0.000)$ & $(0.000)$ & $(0.000)$ & $(0.000)$ \\
\hline Macro-Region Dummies & Yes & Yes & Yes & Yes & Yes & Yes \\
\hline Number of Countries & 108 & 108 & 108 & 108 & 108 & 108 \\
\hline $\mathrm{R}^{2}$ & 0.66 & 0.59 & 0.62 & 0.51 & 0.60 & 0.39 \\
\hline \multirow[t]{2}{*}{ Model F Statistic [p-value] } & $18.44[0.000]$ & $10.48[0.000]$ & $13.05[0.000]$ & $11.28[0.000]$ & $9.98[0.000]$ & $11.12[0.000]$ \\
\hline & & & & & & \\
\hline \multirow[t]{2}{*}{ Area Equipped for Irrigation ${ }_{c}^{1900}$} & $\cdots$ & $0.144 * * * *$ & $\cdots$ & $0.142 * * * *$ & $\cdots$ & $0.140 * * * *$ \\
\hline & & $(0.024)$ & & $(0.024)$ & & $(0.025)$ \\
\hline First-Stage F Statistic on Excluded IV [p-value] & $\ldots$ & $36.49[0.000]$ & $\ldots$ & $34.96[0.000]$ & $\ldots$ & $31.68[0.000]$ \\
\hline
\end{tabular}

\footnotetext{
Notes: $* p<0.1 ; * * p<0.05 ; * * * p<0.01 ; * * * * p<0.001$. Robust standard errors are reported in parentheses. All specifications include a constant term. (d) denotes a binary variable. The variable $\log \left(\right.$ Employment $\left.\mathrm{c}_{\mathrm{c}}^{2000}\right)$ has been removed from the employment growth equations, while the variable $\log \left(\right.$ Employment $\mathrm{t}_{\mathrm{c}}^{\text {Avg. } 1991 \text { to } 2000}$ ) has been removed from the GDP per capita and labour productivity equations due to high correlation with the variable Urban Concentration ${ }_{\mathrm{c}}^{2000}$, i.e., -0.759 and -0.760 , respectively. Table A2 (Online Appendix A) reports the definition of the variables. The full set of firststage estimates of the TSLS is available upon request.
} 
Table C2: The economic returns of urban concentration - Robustness test controlling simultaneously for growth-initial employment, GDP per capita, and labour productivity variables.

\begin{tabular}{|c|c|c|c|c|c|c|}
\hline \multirow{2}{*}{$\begin{array}{l}\text { Dependent Variable } \\
\text { Estimation Method }\end{array}$} & \multicolumn{2}{|c|}{ 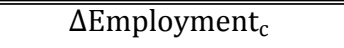 } & \multicolumn{2}{|c|}{$\Delta$ GDP Per Capita $_{\mathrm{c}}$} & \multicolumn{2}{|c|}{ 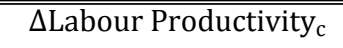 } \\
\hline & OLS & TSLS & OLS & TSLS & OLS & TSLS \\
\hline \multirow{3}{*}{ Urban Concentration $_{\mathrm{c}}^{2000}$} & (1) & (2) & (3) & (4) & (5) & (6) \\
\hline & -0.010 & $-0.031 * *$ & $0.017 * *$ & $0.053 * * *$ & $0.016^{*}$ & $0.078 * * * *$ \\
\hline & $(0.006)$ & $(0.014)$ & $(0.007)$ & $(0.017)$ & $(0.008)$ & $(0.020)$ \\
\hline \multirow[t]{2}{*}{$\log \left(\right.$ Employment $\left._{\mathrm{c}}^{2000}\right)$} & $-0.012 * *$ & $-0.005 * * *$ & $0.005^{* * *}$ & $0.009 * * * *$ & -0.014 & -0.016 \\
\hline & $(0.005)$ & $(0.002)$ & $(0.002)$ & $(0.002)$ & $(0.032)$ & $(0.032)$ \\
\hline \multirow[t]{2}{*}{$\log ($ GDP Per Capita 2000$)$} & -0.008 & -0.010 & $-0.024 * * *$ & $-0.022 * * *$ & 0.014 & 0.001 \\
\hline & $(0.006)$ & $(0.006)$ & $(0.007)$ & $(0.008)$ & $(0.009)$ & $(0.012)$ \\
\hline \multirow[t]{2}{*}{$\log \left(\right.$ Labour Productivity $\left.{ }_{c}^{2000}\right)$} & 0.010 & $0.011^{*}$ & 0.009 & 0.004 & $-0.025 * * *$ & $-0.019^{*}$ \\
\hline & $(0.006)$ & $(0.006)$ & $(0.007)$ & $(0.008)$ & $(0.008)$ & $(0.009)$ \\
\hline \multirow[t]{2}{*}{ Gross Fixed Capital Formation to GDP Avg. 1990 to 2000} & -0.017 & -0.027 & 0.001 & 0.009 & 0.009 & 0.009 \\
\hline & $(0.026)$ & $(0.024)$ & $(0.034)$ & $(0.035)$ & $(0.025)$ & $(0.038)$ \\
\hline \multirow[t]{2}{*}{ 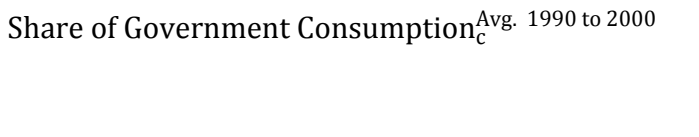 } & -0.010 & -0.006 & 0.004 & -0.011 & 0.016 & -0.015 \\
\hline & $(0.015)$ & $(0.015)$ & $(0.022)$ & $(0.025)$ & $(0.024)$ & $(0.029)$ \\
\hline \multirow[t]{2}{*}{ Oil Rent to GDP Avg. 1990 to 2000} & $0.030 *$ & $0.030 * *$ & 0.002 & 0.024 & -0.026 & 0.022 \\
\hline & $(0.018)$ & $(0.014)$ & $(0.029)$ & $(0.023)$ & $(0.020)$ & $(0.028)$ \\
\hline \multirow[t]{2}{*}{ Openess ${ }_{\mathrm{C}}^{\text {Avg. }} 1990$ to 2000} & $0.010^{*}$ & $0.011 * *$ & $0.016^{* * *}$ & $0.014 * * *$ & 0.008 & $0.010^{*}$ \\
\hline & $(0.005)$ & $(0.005)$ & $(0.005)$ & $(0.005)$ & $(0.005)$ & $(0.006)$ \\
\hline \multirow[t]{2}{*}{ Share of High Tech Export $t_{c}^{\text {Avg. }} 1990$ to 2000} & 0.005 & 0.007 & -0.014 & -0.016 & 0.003 & -0.007 \\
\hline & $(0.009)$ & $(0.010)$ & $(0.013)$ & $(0.011)$ & $(0.011)$ & $(0.015)$ \\
\hline \multirow[t]{2}{*}{ High Income $_{c}(\mathrm{~d})$} & -0.002 & -0.003 & $0.015^{* * *}$ & $0.016^{* * * *}$ & $0.008^{*}$ & $0.012 * *$ \\
\hline & $(0.003)$ & $(0.003)$ & $(0.004)$ & $(0.005)$ & $(0.005)$ & $(0.005)$ \\
\hline \multirow[t]{2}{*}{ Population Densityc Avg. 1990 to 2000} & 0.000 & 0.000 & 0.000 & 0.000 & 0.000 & 0.000 \\
\hline & $(0.000)$ & $(0.000)$ & $(0.000)$ & $(0.000)$ & $(0.000)$ & $(0.000)$ \\
\hline \multirow[t]{2}{*}{ Years of Schooling Avg. 1990, 1995, 2000} & $-0.002 *$ & $-0.002 * *$ & $0.003 * * *$ & $0.004 * * * *$ & $0.003^{* *}$ & $0.004 * * *$ \\
\hline & $(0.001)$ & $(0.001)$ & $(0.001)$ & $(0.001)$ & $(0.001)$ & $(0.001)$ \\
\hline \multirow[t]{2}{*}{ 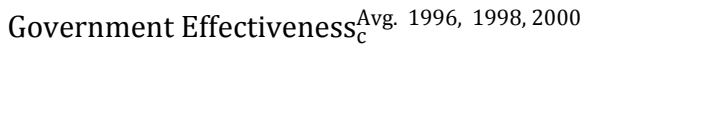 } & -0.000 & 0.002 & 0.002 & 0.002 & -0.000 & 0.002 \\
\hline & $(0.003)$ & $(0.002)$ & $(0.003)$ & $(0.003)$ & $(0.004)$ & $(0.004)$ \\
\hline
\end{tabular}




\begin{tabular}{|c|c|c|c|c|c|c|}
\hline \multirow[t]{2}{*}{$\log \left(\right.$ Surface $\left._{c}\right)$} & 0.001 & 0.001 & 0.002 & 0.002 & $0.004 *$ & 0.003 \\
\hline & $(0.002)$ & $(0.001)$ & $(0.002)$ & $(0.002)$ & $(0.002)$ & $(0.002)$ \\
\hline \multirow[t]{2}{*}{$\operatorname{Island}_{\mathrm{c}}(\mathrm{d})$} & -0.002 & -0.000 & 0.000 & -0.001 & -0.000 & -0.000 \\
\hline & $(0.003)$ & $(0.003)$ & $(0.005)$ & $(0.004)$ & $(0.005)$ & $(0.005)$ \\
\hline \multirow[t]{2}{*}{ Landlocked $_{c}(\mathrm{~d})$} & $0.005^{*}$ & $0.005^{*}$ & -0.002 & -0.002 & $-0.009^{* * *}$ & -0.006 \\
\hline & $(0.003)$ & $(0.002)$ & $(0.003)$ & $(0.004)$ & $(0.003)$ & $(0.004)$ \\
\hline \multirow[t]{2}{*}{ Latitude $_{c}$} & $-0.002 * *$ & -0.000 & 0.000 & 0.000 & 0.000 & 0.000 \\
\hline & $(0.001)$ & $(0.000)$ & $(0.000)$ & $(0.000)$ & $(0.000)$ & $(0.000)$ \\
\hline \multirow[t]{2}{*}{ Longitude $_{\mathrm{c}}$} & -0.000 & -0.000 & 0.000 & -0.000 & -0.000 & $-0.000 * * *$ \\
\hline & $(0.000)$ & $(0.000)$ & $(0.000)$ & $(0.000)$ & $(0.000)$ & $(0.000)$ \\
\hline Macro-Region Dummies & Yes & Yes & Yes & Yes & Yes & Yes \\
\hline Number of Countries & 108 & 108 & 108 & 108 & 108 & 108 \\
\hline $\mathrm{R}^{2}$ & 0.71 & 0.63 & 0.86 & 0.55 & 0.66 & 0.44 \\
\hline \multirow[t]{2}{*}{ Model F Statistic [p-value] } & $22.12[0.000]$ & $14.85[0.000]$ & $23.53[0.000]$ & $19.64[0.000]$ & $9.31[0.000]$ & $17.14[0.000]$ \\
\hline & & & & & & \\
\hline \multirow[t]{2}{*}{ Area Equipped for Irrigation ${ }_{c}^{1900}$} & $\cdots$ & $0.196^{* * * *}$ & $\cdots$ & $0.196^{* * * *}$ & $\cdots$ & $0.196^{* * * *}$ \\
\hline & & $(0.043)$ & & $(0.043)$ & & $(0.043)$ \\
\hline First-Stage F Statistic on Excluded IV [p-value] & $\ldots$ & $20.61[0.000]$ & $\ldots$ & $20.61[0.000]$ & $\ldots$ & $20.61[0.000]$ \\
\hline
\end{tabular}

Notes: $* p<0.1 ; * * p<0.05 ; * * * p<0.01 ; * * * * p<0.001$. Robust standard errors are reported in parentheses. All specifications include a constant term. (d) denotes a binary variable. Table A2 (Online Appendix A) reports the definition of the variables. The full set of first-stage estimates of the TSLS is available upon request. 
Table C3: The economic returns of urban concentration - Robustness test controlling for minimum, mean, and maximum latitude and longitude values.

\begin{tabular}{|c|c|c|c|c|c|c|}
\hline \multirow{2}{*}{$\begin{array}{l}\text { Dependent Variable } \\
\text { Estimation Method }\end{array}$} & \multicolumn{2}{|c|}{ 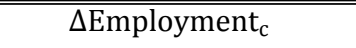 } & \multicolumn{2}{|c|}{ 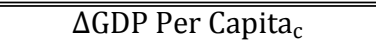 } & \multicolumn{2}{|c|}{ 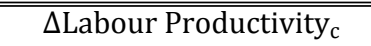 } \\
\hline & OLS & TSLS & OLS & TSLS & OLS & TSLS \\
\hline \multirow{3}{*}{ Urban Concentration $_{\mathrm{c}}^{2000}$} & (1) & (2) & (3) & (4) & (5) & (6) \\
\hline & -0.009 & $-0.043 * * *$ & $0.015^{*}$ & $0.076^{* *}$ & $0.021 * *$ & $0.114 * * *$ \\
\hline & $(0.006)$ & $(0.016)$ & $(0.009)$ & $(0.031)$ & $(0.009)$ & $(0.037)$ \\
\hline \multirow[t]{2}{*}{$\log \left(\right.$ Employment $\left._{\mathrm{c}}^{2000}\right)$} & $-0.003 * *$ & $-0.008 * * * *$ & ... & $\cdots$ & $\ldots$ & $\cdots$ \\
\hline & $(0.001)$ & $(0.002)$ & & & & \\
\hline \multirow[t]{2}{*}{$\log \left(\right.$ GDP Per Capita $\left.{ }_{c}^{2000}\right)$} & $\cdots$ & $\cdots$ & $-0.016^{* * * *}$ & $-0.019 * * * *$ & $\cdots$ & $\cdots$ \\
\hline & & & $(0.003)$ & $(0.004)$ & & \\
\hline \multirow[t]{2}{*}{$\log \left(\right.$ Labour Productivity $\left.{ }_{c}^{2000}\right)$} & $\cdots$ & $\ldots$ & $\ldots$ & $\ldots$ & $-0.015 * * * *$ & $-0.019 * * * *$ \\
\hline & & & & & $(0.003)$ & $(0.004)$ \\
\hline \multirow[t]{2}{*}{$\log \left(\right.$ Employment $\left._{\mathrm{c}}^{\text {Avg. } 1991 \text { to } 2000}\right)$} & $\ldots$ & $\cdots$ & 0.004 & $0.012 * * *$ & $0.004^{*}$ & $0.017 * * * *$ \\
\hline & & & $(0.002)$ & $(0.004)$ & $(0.002)$ & $(0.005)$ \\
\hline \multirow[t]{2}{*}{$\log \left(\right.$ GDP Per Capita ${ }_{c}^{\text {Avg. }} 1990$ to 2000) } & -0.000 & 0.001 & $\ldots$ & $\ldots$ & $\cdots$ & $\cdots$ \\
\hline & $(0.002)$ & $(0.002)$ & & & & \\
\hline \multirow[t]{2}{*}{ Gross Fixed Capital Formation to GDP Avg. 1990 to 2000} & -0.008 & -0.001 & 0.030 & 0.021 & 0.021 & 0.011 \\
\hline & $(0.025)$ & $(0.027)$ & $(0.029)$ & $(0.041)$ & $(0.027)$ & $(0.049)$ \\
\hline \multirow[t]{2}{*}{ 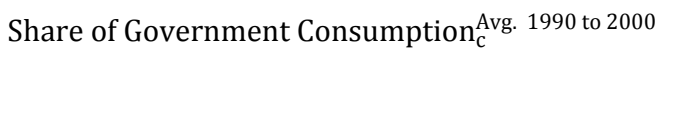 } & -0.016 & -0.010 & -0.007 & -0.021 & -0.003 & -0.022 \\
\hline & $(0.014)$ & $(0.019)$ & $(0.024)$ & $(0.030)$ & $(0.020)$ & $(0.034)$ \\
\hline \multirow[t]{2}{*}{ Oil Rent to GDP Avg. 1990 to 2000} & $0.039 * *$ & 0.020 & -0.006 & 0.033 & -0.020 & 0.036 \\
\hline & $(0.017)$ & $(0.018)$ & $(0.020)$ & $(0.031)$ & $(0.019)$ & $(0.037)$ \\
\hline \multirow[t]{2}{*}{ 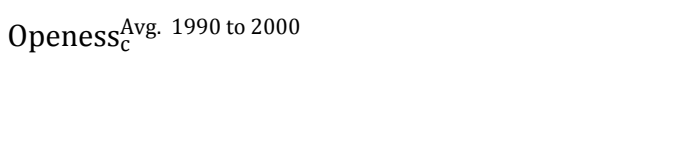 } & $0.011 * *$ & $0.011 * *$ & $0.014 * *$ & $0.013^{* *}$ & 0.009 & 0.008 \\
\hline & $(0.005)$ & $(0.006)$ & $(0.005)$ & $(0.006)$ & $(0.006)$ & $(0.008)$ \\
\hline \multirow[t]{2}{*}{ Share of High Tech Export Avg. 1990 to 2000} & 0.004 & 0.007 & -0.016 & -0.021 & -0.006 & -0.014 \\
\hline & $(0.009)$ & $(0.011)$ & $(0.010)$ & $(0.014)$ & $(0.012)$ & $(0.019)$ \\
\hline \multirow[t]{2}{*}{ High Income $_{c}(d)$} & -0.002 & -0.003 & $0.015 * * *$ & $0.017 * * *$ & $0.012 * *$ & $0.014 * *$ \\
\hline & $(0.003)$ & $(0.003)$ & $(0.005)$ & $(0.006)$ & $(0.005)$ & $(0.007)$ \\
\hline \multirow[t]{2}{*}{ Population Density Avg. 1990 to 2000} & 0.000 & 0.000 & 0.000 & 0.000 & -0.000 & -0.000 \\
\hline & $(0.000)$ & $(0.000)$ & $(0.000)$ & $(0.000)$ & $(0.000)$ & $(0.000)$ \\
\hline
\end{tabular}




\begin{tabular}{|c|c|c|c|c|c|c|}
\hline \multirow[t]{2}{*}{ 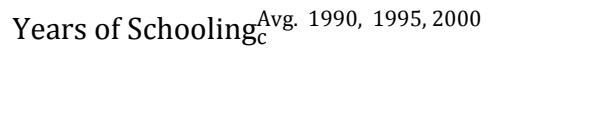 } & -0.001 & $-0.002 * *$ & $0.003 * * *$ & $0.004 * * *$ & $0.003 * * *$ & $0.005 * * *$ \\
\hline & $(0.001)$ & $(0.001)$ & $(0.001)$ & $(0.001)$ & $(0.001)$ & $(0.002)$ \\
\hline \multirow[t]{2}{*}{ 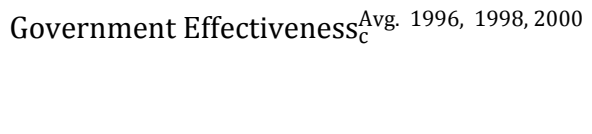 } & 0.001 & 0.002 & 0.002 & 0.003 & 0.002 & 0.002 \\
\hline & $(0.002)$ & $(0.003)$ & $(0.003)$ & $(0.004)$ & $(0.003)$ & $(0.004)$ \\
\hline \multirow[t]{2}{*}{$\log \left(\right.$ Surface $\left._{c}\right)$} & 0.002 & 0.001 & 0.002 & 0.003 & 0.002 & 0.004 \\
\hline & $(0.001)$ & $(0.001)$ & $(0.002)$ & $(0.003)$ & $(0.002)$ & $(0.003)$ \\
\hline \multirow[t]{2}{*}{ Island $_{c}(\mathrm{~d})$} & -0.001 & -0.000 & -0.000 & -0.001 & 0.000 & -0.001 \\
\hline & $(0.003)$ & $(0.003)$ & $(0.005)$ & $(0.005)$ & $(0.005)$ & $(0.006)$ \\
\hline \multirow[t]{2}{*}{ Landlocked $_{c}(\mathrm{~d})$} & $0.004 *$ & 0.004 & -0.004 & -0.003 & $-0.007 *$ & -0.007 \\
\hline & $(0.002)$ & $(0.003)$ & $(0.003)$ & $(0.004)$ & $(0.004)$ & $(0.005)$ \\
\hline \multirow[t]{2}{*}{ Minimum Latitude $_{c}$} & -0.000 & -0.000 & 0.000 & 0.000 & 0.000 & 0.000 \\
\hline & $(0.000)$ & $(0.000)$ & $(0.000)$ & $(0.000)$ & $(0.000)$ & $(0.001)$ \\
\hline \multirow[t]{2}{*}{ Mean Latitude $_{c}$} & -0.000 & -0.000 & -0.000 & 0.000 & -0.000 & 0.000 \\
\hline & $(0.000)$ & $(0.000)$ & $(0.000)$ & $(0.001)$ & $(0.001)$ & $(0.001)$ \\
\hline \multirow[t]{2}{*}{ Maximum Latitude $_{c}$} & 0.000 & 0.000 & 0.000 & -0.000 & 0.000 & -0.001 \\
\hline & $(0.000)$ & $(0.000)$ & $(0.000)$ & $(0.000)$ & $(0.000)$ & $(0.001)$ \\
\hline \multirow[t]{2}{*}{ Minimum Longitude $_{c}$} & $-0.000 * *$ & -0.000 & 0.000 & 0.000 & 0.000 & -0.000 \\
\hline & $(0.000)$ & $(0.000)$ & $(0.000)$ & $(0.000)$ & $(0.000)$ & $(0.000)$ \\
\hline \multirow[t]{2}{*}{ Mean Longitude $_{c}$} & $-0.000 * *$ & -0.000 & 0.000 & -0.000 & -0.000 & $-0.000 * *$ \\
\hline & $(0.000)$ & $(0.000)$ & $(0.000)$ & $(0.000)$ & $(0.000)$ & $(0.000)$ \\
\hline \multirow[t]{2}{*}{ Maximum Longitude $_{c}$} & -0.000 & 0.000 & -0.000 & $-0.000 *$ & -0.000 & $-0.000 * *$ \\
\hline & $(0.000)$ & $(0.000)$ & $(0.000)$ & $(0.000)$ & $(0.000)$ & $(0.000)$ \\
\hline Macro-Region Dummies & Yes & Yes & Yes & Yes & Yes & Yes \\
\hline Number of Countries & 108 & 108 & 108 & 108 & 108 & 108 \\
\hline $\mathrm{R}^{2}$ & 0.68 & 0.56 & 0.62 & 0.41 & 0.61 & 0.15 \\
\hline Model F Statistic [p-value] & $25.58[0.000]$ & $52.17[0.000]$ & $10.82[0.000]$ & $10.90[0.000]$ & $8.02[0.000]$ & $8.80[0.000]$ \\
\hline
\end{tabular}

First-Stage Estimation

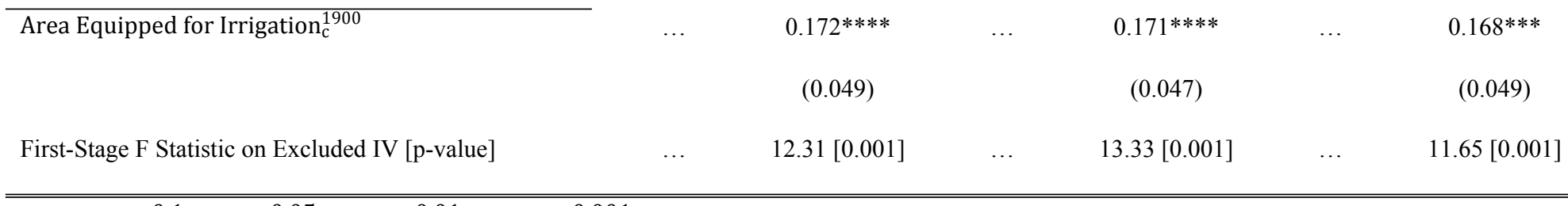

Notes: $* p<0.1 ; * * p<0.05 ; * * * p<0.01 ; * * * * p<0.001$. Robust standard errors are reported in parentheses. All specifications include a constant term. (d) denotes a binary variable. Table A2 (Online Appendix A) reports the definition of the variables. The full set of first-stage estimates of the TSLS is available upon request. 
Table C4: The economic returns of urban concentration - Robustness test controlling for countryspecific number of FUAs.

\begin{tabular}{|c|c|c|c|c|c|c|}
\hline \multirow{2}{*}{$\begin{array}{l}\text { Dependent Variable } \\
\text { Estimation Method }\end{array}$} & \multicolumn{2}{|c|}{ 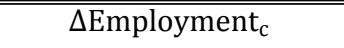 } & \multicolumn{2}{|c|}{$\bar{~} \Delta$ GDP Per Capita $_{\mathrm{c}}$} & \multicolumn{2}{|c|}{ 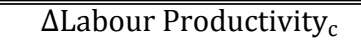 } \\
\hline & OLS & TSLS & OLS & TSLS & OLS & TSLS \\
\hline \multirow{3}{*}{ Urban Concentration $_{\mathrm{c}}^{2000}$} & (1) & (2) & (3) & (4) & (5) & (6) \\
\hline & -0.003 & $-0.027 * * *$ & $0.016^{* *}$ & $0.054 * * *$ & $0.018 * *$ & $0.072 * * * *$ \\
\hline & $(0.008)$ & $(0.010)$ & $(0.008)$ & $(0.017)$ & $(0.008)$ & $(0.018)$ \\
\hline \multirow[t]{2}{*}{$\log \left(\right.$ Employment $\left._{c}^{2000}\right)$} & $-0.005 * *$ & $-0.004 *$ & $\ldots$ & $\ldots$ & $\ldots$ & $\ldots$ \\
\hline & $(0.002)$ & $(0.002)$ & & & & \\
\hline \multirow[t]{2}{*}{$\log \left(\right.$ GDP Per Capita $\left.{ }_{c}^{2000}\right)$} & $\cdots$ & $\cdots$ & $-0.014 * * * *$ & $-0.018 * * * *$ & $\cdots$ & $\cdots$ \\
\hline & & & $(0.003)$ & $(0.003)$ & & \\
\hline \multirow[t]{2}{*}{$\log \left(\right.$ Labour Productivity $\left.{ }_{c}^{2000}\right)$} & $\ldots$ & $\ldots$ & $\ldots$ & $\ldots$ & $-0.015 * * * *$ & $-0.018 * * * *$ \\
\hline & & & & & $(0.003)$ & $(0.003)$ \\
\hline \multirow[t]{2}{*}{$\log \left(\right.$ Employment $\left._{\mathrm{c}}^{\text {Avg. } 1991 \text { to } 2000}\right)$} & $\ldots$ & $\ldots$ & -0.000 & 0.004 & 0.003 & 0.003 \\
\hline & & & $(0.007)$ & $(0.004)$ & $(0.002)$ & $(0.004)$ \\
\hline \multirow[t]{2}{*}{$\log ($ GDP Per Capita Avg. 1990 to 2000) } & 0.000 & 0.001 & $\ldots$ & $\ldots$ & $\ldots$ & $\ldots$ \\
\hline & $(0.002)$ & $(0.002)$ & & & & \\
\hline \multirow[t]{2}{*}{ Gross Fixed Capital Formation to GDP Avg. 1990 to 2000} & -0.017 & -0.007 & 0.021 & 0.024 & 0.023 & 0.015 \\
\hline & $(0.025)$ & $(0.026)$ & $(0.030)$ & $(0.034)$ & $(0.027)$ & $(0.034)$ \\
\hline \multirow[t]{2}{*}{ 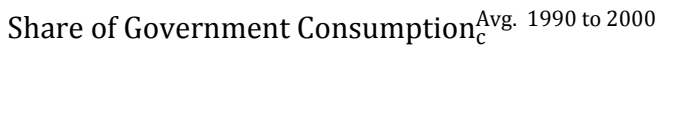 } & -0.015 & -0.008 & -0.002 & -0.020 & -0.005 & -0.023 \\
\hline & $(0.014)$ & $(0.014)$ & $(0.022)$ & $(0.027)$ & $(0.020)$ & $(0.025)$ \\
\hline \multirow[t]{2}{*}{ Oil Rent to GDP Avg. 1990 to 2000} & $0.037 * *$ & $0.031 * *$ & -0.013 & 0.007 & -0.026 & -0.005 \\
\hline & $(0.016)$ & $(0.016)$ & $(0.027)$ & $(0.024)$ & $(0.018)$ & $(0.021)$ \\
\hline \multirow[t]{2}{*}{ Openess ${ }_{c}^{\text {Avg. } 1990 ~ t o ~} 2000$} & $0.011^{* *}$ & $0.010^{* *}$ & $0.015 * * *$ & $0.014 * * *$ & 0.008 & $0.010^{*}$ \\
\hline & $(0.004)$ & $(0.005)$ & $(0.005)$ & $(0.005)$ & $(0.005)$ & $(0.006)$ \\
\hline \multirow[t]{2}{*}{ Share of High Tech Export Avg. 1990 to 2000} & 0.003 & 0.005 & -0.016 & $-0.018 *$ & -0.003 & -0.008 \\
\hline & $(0.008)$ & $(0.009)$ & $(0.012)$ & $(0.011)$ & $(0.011)$ & $(0.012)$ \\
\hline \multirow[t]{2}{*}{ High Income $_{c}(\mathrm{~d})$} & -0.002 & -0.002 & $0.014 * * * *$ & $0.016^{* * *}$ & $0.011 * *$ & $0.013 * *$ \\
\hline & $(0.003)$ & $(0.003)$ & $(0.004)$ & $(0.005)$ & $(0.005)$ & $(0.005)$ \\
\hline \multirow[t]{2}{*}{ Population Densityc Avg. 1990 to 2000} & 0.000 & 0.000 & 0.000 & 0.000 & -0.000 & -0.000 \\
\hline & $(0.000)$ & $(0.000)$ & $(0.000)$ & $(0.000)$ & $(0.000)$ & $(0.000)$ \\
\hline
\end{tabular}




\begin{tabular}{|c|c|c|c|c|c|c|}
\hline \multirow[t]{2}{*}{ Years of Schooling Avg. 1990, 1995, 2000} & -0.001 & $-0.002 * *$ & $0.003 * * *$ & $0.003 * * *$ & $0.003 * * *$ & $0.004 * * * *$ \\
\hline & $(0.001)$ & $(0.001)$ & $(0.001)$ & $(0.001)$ & $(0.001)$ & $(0.001)$ \\
\hline \multirow[t]{2}{*}{ Government Effectiveness Avg. 1996, 1998, 2000} & 0.001 & 0.001 & 0.002 & 0.003 & 0.001 & 0.003 \\
\hline & $(0.002)$ & $(0.002)$ & $(0.003)$ & $(0.003)$ & $(0.003)$ & $(0.003)$ \\
\hline \multirow[t]{2}{*}{$\log \left(\right.$ Surface $\left._{c}\right)$} & $0.002 *$ & $0.002 * *$ & 0.006 & 0.002 & 0.002 & 0.002 \\
\hline & $(0.001)$ & $(0.001)$ & $(0.006)$ & $(0.002)$ & $(0.002)$ & $(0.002)$ \\
\hline \multirow[t]{2}{*}{$\operatorname{Island}_{\mathrm{c}}(\mathrm{d})$} & -0.001 & 0.000 & -0.001 & -0.002 & -0.000 & -0.002 \\
\hline & $(0.003)$ & $(0.003)$ & $(0.004)$ & $(0.005)$ & $(0.005)$ & $(0.005)$ \\
\hline \multirow[t]{2}{*}{ Landlocked $_{c}(\mathrm{~d})$} & $0.004 * *$ & 0.003 & -0.003 & -0.001 & $-0.007^{*}$ & -0.004 \\
\hline & $(0.002)$ & $(0.002)$ & $(0.003)$ & $(0.004)$ & $(0.004)$ & $(0.004)$ \\
\hline \multirow[t]{2}{*}{ Latitude $_{c}$} & -0.000 & -0.000 & 0.000 & 0.000 & 0.000 & 0.000 \\
\hline & $(0.000)$ & $(0.000)$ & $(0.000)$ & $(0.000)$ & $(0.000)$ & $(0.000)$ \\
\hline \multirow[t]{2}{*}{ Longitude $_{c}$} & $-0.000^{*}$ & -0.000 & 0.000 & -0.000 & -0.000 & -0.000 \\
\hline & $(0.000)$ & $(0.000)$ & $(0.000)$ & $(0.000)$ & $(0.000)$ & $(0.000)$ \\
\hline \multirow[t]{2}{*}{$\log \left(\right.$ Number $\left.\mathrm{FUA}_{\mathrm{c}}^{2000}\right)$} & 0.003 & -0.002 & 0.005 & 0.005 & $0.008 * *$ & $0.009^{*}$ \\
\hline & $(0.003)$ & $(0.002)$ & $(0.004)$ & $(0.005)$ & $(0.004)$ & $(0.005)$ \\
\hline Macro-Region Dummies & Yes & Yes & Yes & Yes & Yes & Yes \\
\hline Number of Countries & 108 & 108 & 108 & 108 & 108 & 108 \\
\hline $\mathrm{R}^{2}$ & 0.68 & 0.64 & 0.85 & 0.55 & 0.62 & 0.51 \\
\hline \multirow[t]{2}{*}{ Model F Statistic [p-value] } & $17.17[0.000]$ & $15.70[0.000]$ & $21.23[0.000]$ & $11.25[0.000]$ & $10.41[0.000]$ & $11.66[0.000]$ \\
\hline & & & & & & \\
\hline \multirow[t]{2}{*}{ Area Equipped for Irrigation ${ }_{c}^{1900}$} & $\cdots$ & $0.259 * * * *$ & $\cdots$ & $0.257 * * * *$ & $\cdots$ & $0.266^{* * * *}$ \\
\hline & & $(0.039)$ & & $(0.040)$ & & $(0.036)$ \\
\hline First-Stage F Statistic on Excluded IV [p-value] & $\ldots$ & $43.01[0.000]$ & $\ldots$ & $41.75[0.000]$ & $\ldots$ & $54.35[0.000]$ \\
\hline
\end{tabular}

Notes: $* p<0.1 ; * * p<0.05 ; * * * p<0.01 ; * * * * p<0.001$. Robust standard errors are reported in parentheses. All specifications include a constant term. (d) denotes a binary variable. Table A2 (Online Appendix A) reports the definition of the variables. The full set of first-stage estimates of the TSLS is available upon request. 
Table C5: The economic returns of urban concentration - Robustness test controlling for countrylevel percentage of urban population.

\begin{tabular}{|c|c|c|c|c|c|c|}
\hline \multirow{2}{*}{$\begin{array}{l}\text { Dependent Variable } \\
\text { Estimation Method }\end{array}$} & \multicolumn{2}{|c|}{$\Delta$ Employment $_{\mathrm{c}}$} & \multicolumn{2}{|c|}{$\Delta$ GDP Per Capita $_{\mathrm{c}}$} & \multicolumn{2}{|c|}{ 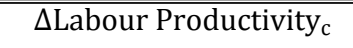 } \\
\hline & OLS & TSLS & OLS & TSLS & OLS & TSLS \\
\hline \multirow{3}{*}{ Urban Concentration $_{\mathrm{c}}^{2000}$} & (1) & (2) & (3) & (4) & (5) & (6) \\
\hline & -0.008 & $-0.028 * *$ & $0.015^{*}$ & $0.064 * * *$ & $0.021 * *$ & $0.087 * * * *$ \\
\hline & $(0.006)$ & $(0.014)$ & $(0.009)$ & $(0.022)$ & $(0.009)$ & $(0.023)$ \\
\hline \multirow[t]{2}{*}{$\log \left(\right.$ Employment $\left._{\mathrm{c}}^{2000}\right)$} & $-0.002 *$ & $-0.005 * *$ & $\cdots$ & $\ldots$ & $\ldots$ & $\ldots$ \\
\hline & $(0.001)$ & $(0.002)$ & & & & \\
\hline \multirow[t]{2}{*}{$\log \left(\right.$ GDP Per Capita $\left.{ }_{c}^{2000}\right)$} & $\cdots$ & $\cdots$ & $-0.016^{* * * *}$ & $-0.020 * * * *$ & $\cdots$ & $\cdots$ \\
\hline & & & $(0.003)$ & $(0.004)$ & & \\
\hline \multirow[t]{2}{*}{$\log \left(\right.$ Labour Productivity $\left._{c}^{2000}\right)$} & $\ldots$ & $\ldots$ & $\ldots$ & $\ldots$ & $-0.015 * * * *$ & $-0.019 * * * *$ \\
\hline & & & & & $(0.004)$ & $(0.004)$ \\
\hline \multirow[t]{2}{*}{$\log \left(\right.$ Employment $\left._{\mathrm{c}}^{\text {Avg. } 1991 \text { to } 2000}\right)$} & .. & $\ldots$ & 0.004 & $0.010^{* * * *}$ & 0.004 & $0.013^{* * * *}$ \\
\hline & & & $(0.002)$ & $(0.003)$ & $(0.002)$ & $(0.003)$ \\
\hline \multirow[t]{2}{*}{$\log \left(\right.$ GDP Per Capita ${ }_{c}^{\text {Avg. } 1990 \text { to 2000) }}$} & -0.001 & -0.000 & $\cdots$ & $\cdots$ & $\cdots$ & $\cdots$ \\
\hline & $(0.002)$ & $(0.002)$ & & & & \\
\hline \multirow[t]{2}{*}{ Gross Fixed Capital Formation to GDP ${ }_{c}^{\text {Avg. }} 1990$ to 2000} & -0.013 & -0.009 & 0.034 & 0.029 & 0.025 & 0.020 \\
\hline & $(0.024)$ & $(0.025)$ & $(0.029)$ & $(0.037)$ & $(0.028)$ & $(0.040)$ \\
\hline \multirow[t]{2}{*}{ 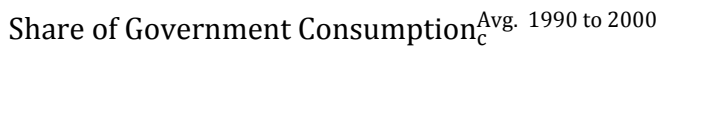 } & -0.016 & -0.010 & -0.006 & -0.024 & -0.002 & -0.023 \\
\hline & $(0.014)$ & $(0.015)$ & $(0.024)$ & $(0.029)$ & $(0.020)$ & $(0.029)$ \\
\hline \multirow[t]{2}{*}{ Oil Rent to GDP Avg. 1990 to 2000} & $0.040 * *$ & $0.029 * *$ & -0.006 & 0.025 & -0.019 & 0.019 \\
\hline & $(0.016)$ & $(0.015)$ & $(0.020)$ & $(0.026)$ & $(0.018)$ & $(0.026)$ \\
\hline \multirow[t]{2}{*}{ Openess Avg. 1990 to 2000} & $0.011^{* *}$ & $0.010^{* *}$ & $0.013^{* *}$ & $0.014 * * *$ & 0.008 & 0.010 \\
\hline & $(0.004)$ & $(0.005)$ & $(0.005)$ & $(0.005)$ & $(0.005)$ & $(0.006)$ \\
\hline \multirow[t]{2}{*}{ Share of High Tech Export Avg. 1990 to 2000} & 0.003 & 0.005 & -0.015 & $-0.021^{*}$ & -0.005 & -0.012 \\
\hline & $(0.008)$ & $(0.010)$ & $(0.010)$ & $(0.012)$ & $(0.011)$ & $(0.016)$ \\
\hline \multirow[t]{2}{*}{ High Income $_{c}(\mathrm{~d})$} & -0.001 & -0.002 & $0.015 * * *$ & $0.018 * * *$ & $0.011 * *$ & $0.014 * *$ \\
\hline & $(0.002)$ & $(0.002)$ & $(0.005)$ & $(0.005)$ & $(0.005)$ & $(0.006)$ \\
\hline \multirow[t]{2}{*}{ Population Densityc Avg. 1990 to 2000} & 0.000 & 0.000 & 0.000 & 0.000 & 0.000 & -0.000 \\
\hline & $(0.000)$ & $(0.000)$ & $(0.000)$ & $(0.000)$ & $(0.000)$ & $(0.000)$ \\
\hline
\end{tabular}




\begin{tabular}{|c|c|c|c|c|c|c|}
\hline \multirow[t]{2}{*}{ Years of Schooling Avg. 1990, 1995, 2000} & $-0.001 *$ & $-0.002 * *$ & $0.003 * * *$ & $0.003 * * *$ & $0.003 * * *$ & $0.004 * * *$ \\
\hline & $(0.001)$ & $(0.001)$ & $(0.001)$ & $(0.001)$ & $(0.001)$ & $(0.001)$ \\
\hline \multirow{2}{*}{ Government Effectiveness Avg. 1996, 1998, 2000} & 0.001 & 0.002 & 0.003 & 0.003 & 0.002 & 0.002 \\
\hline & $(0.002)$ & $(0.002)$ & $(0.003)$ & $(0.003)$ & $(0.003)$ & $(0.003)$ \\
\hline \multirow[t]{2}{*}{$\log \left(\right.$ Surface $\left._{c}\right)$} & $0.002 *$ & $0.002 *$ & 0.002 & 0.002 & 0.002 & 0.002 \\
\hline & $(0.001)$ & $(0.001)$ & $(0.002)$ & $(0.002)$ & $(0.002)$ & $(0.002)$ \\
\hline \multirow[t]{2}{*}{$\operatorname{Island}_{\mathrm{c}}(\mathrm{d})$} & 0.000 & 0.000 & -0.001 & -0.000 & -0.001 & -0.000 \\
\hline & $(0.003)$ & $(0.003)$ & $(0.005)$ & $(0.005)$ & $(0.005)$ & $(0.006)$ \\
\hline \multirow[t]{2}{*}{ Landlocked $_{c}(\mathrm{~d})$} & $0.004^{*}$ & 0.004 & -0.004 & -0.002 & $-0.007^{*}$ & -0.006 \\
\hline & $(0.002)$ & $(0.003)$ & $(0.003)$ & $(0.004)$ & $(0.004)$ & $(0.005)$ \\
\hline \multirow[t]{2}{*}{ Latitude $_{c}$} & -0.000 & -0.000 & 0.000 & 0.000 & 0.000 & 0.000 \\
\hline & $(0.000)$ & $(0.000)$ & $(0.000)$ & $(0.000)$ & $(0.000)$ & $(0.000)$ \\
\hline \multirow[t]{2}{*}{ Longitude $_{c}$} & $-0.000 * *$ & -0.000 & -0.000 & -0.000 & -0.000 & $-0.000 * * *$ \\
\hline & $(0.000)$ & $(0.000)$ & $(0.000)$ & $(0.000)$ & $(0.000)$ & $(0.000)$ \\
\hline \multirow[t]{2}{*}{ Percentage Urban Population Avg. 1990 to 2000} & 0.012 & 0.007 & -0.002 & 0.009 & -0.008 & 0.007 \\
\hline & $(0.010)$ & $(0.012)$ & $(0.012)$ & $(0.015)$ & $(0.013)$ & $(0.018)$ \\
\hline Macro-Region Dummies & Yes & Yes & Yes & Yes & Yes & Yes \\
\hline Number of Countries & 108 & 108 & 108 & 108 & 108 & 108 \\
\hline $\mathrm{R}^{2}$ & 0.68 & 0.64 & 0.62 & 0.48 & 0.61 & 0.37 \\
\hline Model F Statistic [p-value] & $14.46[0.000]$ & $14.75[0.000]$ & $14.49[0.000]$ & $11.78[0.000]$ & $9.63[0.000]$ & $14.94[0.000]$ \\
\hline
\end{tabular}

First-Stage Estimation

\begin{tabular}{lccccc}
\hline Area Equipped for Irrigation $\mathrm{c}_{\mathrm{c}}^{1900}$ & $\ldots$ & $0.188^{* * * *}$ & $\ldots$ & $0.188^{* * * *}$ & $(0.038)$ \\
& & $(0.041)$ & & $(0.043)$ \\
First-Stage F Statistic on Excluded IV [p-value] & $\ldots$ & $20.74[0.000]$ & $\ldots$ & $24.37[0.000] \quad \ldots$ & $19.12[0.000]$
\end{tabular}

Notes: $* p<0.1 ; * * p<0.05 ; * * * p<0.01 ; * * * * p<0.001$. Robust standard errors are reported in parentheses. All specifications include a constant term. (d) denotes a binary variable. Table A2 (Online Appendix A) reports the definition of the variables. The full set of first-stage estimates of the TSLS is available upon request. 
Table C6: The economic returns of urban concentration - Robustness test on TSLS estimates with statistically significant control variables only.

\begin{tabular}{|c|c|c|c|}
\hline Dependent Variable & 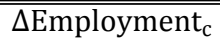 & 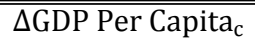 & 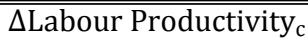 \\
\hline & (1) & (2) & (3) \\
\hline \multirow[t]{2}{*}{ Urban Concentration $_{\mathrm{c}}^{2000}$} & $-0.037 * *$ & $0.069^{* * * *}$ & $0.094 * * * *$ \\
\hline & $(0.015)$ & $(0.019)$ & $(0.022)$ \\
\hline \multirow[t]{2}{*}{$\log \left(\right.$ Employment $\left._{c}^{2000}\right)$} & $-0.005 * * *$ & $\ldots$ & $\ldots$ \\
\hline & $(0.002)$ & & \\
\hline \multirow[t]{2}{*}{$\log \left(\right.$ GDP Per Capita $\left.{ }_{c}^{2000}\right)$} & $\cdots$ & $-0.016 * * * *$ & $\cdots$ \\
\hline & & $(0.002)$ & \\
\hline \multirow[t]{2}{*}{$\log \left(\right.$ Labour Productivity $\left._{c}^{2000}\right)$} & $\ldots$ & ... & $-0.016^{* * * *}$ \\
\hline & & & $(0.002)$ \\
\hline \multirow[t]{2}{*}{$\log \left(\right.$ Employment $\left._{\mathrm{c}}^{\text {Avg. } 1991 \text { to } 2000}\right)$} & $\ldots$ & $0.014^{* * * *}$ & $0.015^{* * * *}$ \\
\hline & & $(0.002)$ & $(0.003)$ \\
\hline \multirow[t]{2}{*}{ Oil Rent to GDP Avg. 1990 to 2000} & $0.023^{*}$ & $\cdots$ & $\cdots$ \\
\hline & $(0.012)$ & & \\
\hline \multirow[t]{2}{*}{ Openess $_{c}^{\text {Avg. }} 1990$ to 2000} & $0.009^{* *}$ & $0.015^{* * *}$ & $\cdots$ \\
\hline & $(0.004)$ & $(0.005)$ & \\
\hline \multirow[t]{2}{*}{ Share of High Tech Export ${ }_{c}^{\text {Avg. }} 1990$ to 2000} & $\ldots$ & -0.020 & $\ldots$ \\
\hline & & $(0.013)$ & \\
\hline \multirow[t]{2}{*}{ High Income $_{c}(d)$} & $\ldots$ & $0.019 * * * *$ & $0.015^{* *}$ \\
\hline & & $(0.005)$ & $(0.006)$ \\
\hline \multirow[t]{2}{*}{ 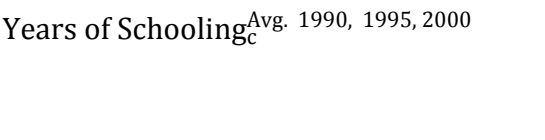 } & $-0.001 * * *$ & $0.003^{* * *}$ & $0.004^{* * * *}$ \\
\hline & $(0.001)$ & $(0.001)$ & $(0.001)$ \\
\hline \multirow[t]{2}{*}{$\log \left(\right.$ Surface $\left._{c}\right)$} & 0.000 & $\cdots$ & $\cdots$ \\
\hline & $(0.001)$ & & \\
\hline \multirow[t]{2}{*}{ Longitude $_{c}$} & $\ldots$ & $-0.000 * *$ & $-0.000 * * *$ \\
\hline & & $(0.000)$ & $(0.000)$ \\
\hline Macro-Region Dummies & Yes & Yes & Yes \\
\hline Number of Countries & 108 & 108 & 108 \\
\hline $\mathrm{R}^{2}$ & 0.53 & 0.40 & 0.23 \\
\hline
\end{tabular}


First-Stage Estimation

Area Equipped for Irrigation $_{\mathrm{c}}^{1900}$

$0.163^{* * * *}$

(0.038)

$18.21[0.000]$
$0.194 * * * *$

(0.037)

$27.92[0.000]$
$0.192 * * * *$

(0.039)

$24.11[0.000]$

First-Stage F Statistic on Excluded IV [p-value]

Notes: $* p<0.1 ; * * p<0.05 ; * * * p<0.01 ; * * * * p<0.001$. TSLS estimates. Robust standard errors are reported in parentheses. All specifications include a constant term. (d) denotes a binary variable. The selected control variables are identified from the corresponding specifications in Table B2 (Online Appendix B). Table A2 (Online Appendix A) reports the definition of the variables. The full set of firststage estimates is available upon request. 
Table C7: The economic returns of urban concentration - Robustness test on TSLS estimates controlling for historical economic development level.

\begin{tabular}{|c|c|c|c|}
\hline Dependent Variable & 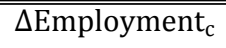 & 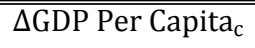 & 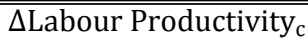 \\
\hline & (1) & (2) & (3) \\
\hline \multirow[t]{2}{*}{ Urban Concentration $_{\mathrm{c}}^{2000}$} & $-0.029 * *$ & $0.059 * * *$ & $0.083 * * * *$ \\
\hline & $(0.013)$ & $(0.019)$ & $(0.020)$ \\
\hline \multirow[t]{2}{*}{$\log \left(\right.$ Employment $\left._{c}^{2000}\right)$} & $-0.006^{* * *}$ & $\ldots$ & $\ldots$ \\
\hline & $(0.002)$ & & \\
\hline \multirow[t]{2}{*}{$\log \left(\right.$ GDP Per Capita $\left.{ }_{c}^{2000}\right)$} & $\cdots$ & $-0.018 * * * *$ & $\cdots$ \\
\hline & & $(0.003)$ & \\
\hline \multirow[t]{2}{*}{$\log \left(\right.$ Labour Productivity $\left.{ }_{c}^{2000}\right)$} & $\ldots$ & ... & $-0.018 * * * *$ \\
\hline & & & $(0.003)$ \\
\hline \multirow[t]{2}{*}{$\log \left(\right.$ Employment $\left._{\mathrm{c}}^{\text {Avg. } 1991 \text { to } 2000}\right)$} & $\ldots$ & $0.010^{* * * *}$ & $0.013^{* * * *}$ \\
\hline & & $(0.003)$ & $(0.003)$ \\
\hline \multirow[t]{2}{*}{$\log \left(\right.$ GDP Per Capita ${ }_{c}^{\text {Avg. }} 1990$ to 2000) } & 0.000 & $\cdots$ & $\cdots$ \\
\hline & $(0.002)$ & & \\
\hline \multirow[t]{2}{*}{ Gross Fixed Capital Formation to GDP Avg. 1990 to 2000} & 0.001 & 0.011 & -0.002 \\
\hline & $(0.025)$ & $(0.035)$ & $(0.039)$ \\
\hline \multirow[t]{2}{*}{ 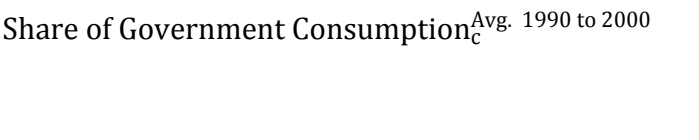 } & -0.008 & -0.019 & -0.021 \\
\hline & $(0.015)$ & $(0.027)$ & $(0.026)$ \\
\hline \multirow[t]{2}{*}{ Oil Rent to GDPAvg. 1990 to 2000} & 0.025 & 0.029 & 0.027 \\
\hline & $(0.016)$ & $(0.026)$ & $(0.027)$ \\
\hline \multirow[t]{2}{*}{ 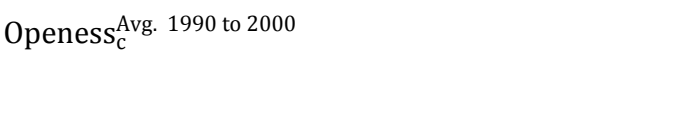 } & $0.010^{* *}$ & $0.014 * * *$ & $0.010^{*}$ \\
\hline & $(0.005)$ & $(0.005)$ & $(0.006)$ \\
\hline \multirow[t]{2}{*}{ Share of High Tech Export ${ }_{c}^{\text {Avg. } 1990 ~ t o ~} 2000$} & 0.007 & $-0.022 *$ & -0.015 \\
\hline & $(0.010)$ & $(0.012)$ & $(0.015)$ \\
\hline \multirow[t]{2}{*}{ High Income $_{c}(\mathrm{~d})$} & -0.002 & $0.017 * * *$ & $0.013 * *$ \\
\hline & $(0.003)$ & $(0.005)$ & $(0.006)$ \\
\hline \multirow[t]{2}{*}{ Population Density ${ }_{c}^{\text {Avg. }} 1990$ to 2000} & 0.000 & 0.000 & -0.000 \\
\hline & $(0.000)$ & $(0.000)$ & $(0.000)$ \\
\hline Years of Schooling Avg. 1990, 1995, 2000 & $-0.002 * *$ & $0.004 * * *$ & $0.004 * * *$ \\
\hline
\end{tabular}




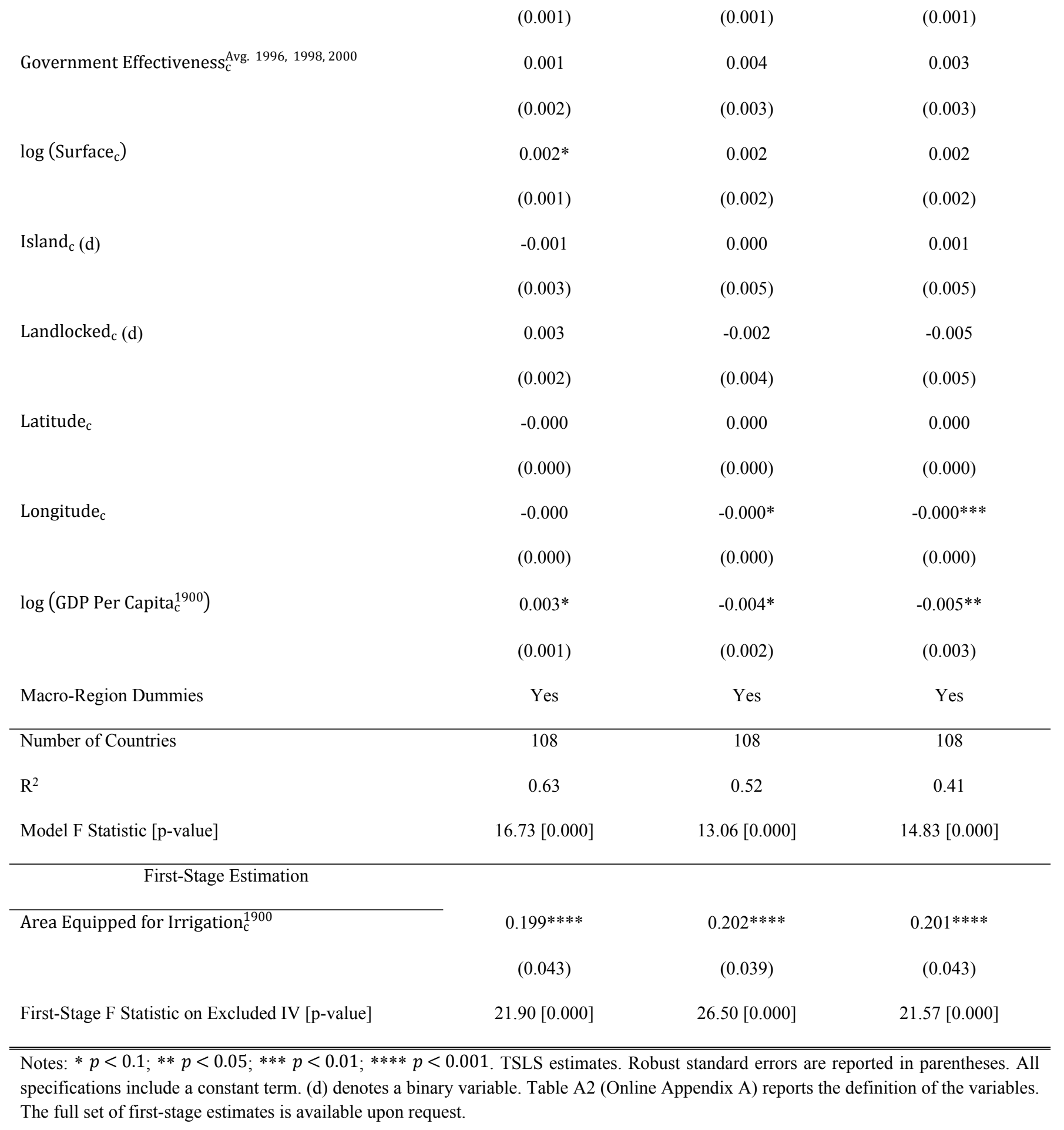


Table C8: The economic returns of urban concentration - Robustness test on TSLS estimates using an over-identified equation with terrain ruggedness and controlling for historical economic development level.

\begin{tabular}{|c|c|c|c|c|c|c|}
\hline \multirow[t]{2}{*}{ Dependent Variable } & \multicolumn{2}{|c|}{ 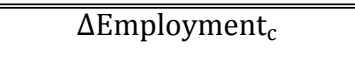 } & \multicolumn{2}{|c|}{ 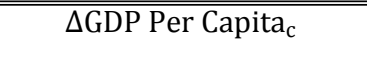 } & \multicolumn{2}{|c|}{$\Delta{\bar{~} \Delta \text { Labour Productivity }_{c}}$} \\
\hline & (1) & (2) & (3) & (4) & (5) & (6) \\
\hline \multirow[t]{2}{*}{ Urban Concentration $_{\mathrm{c}}^{2000}$} & $-0.027 * *$ & $-0.026^{* *}$ & $0.055^{* * *}$ & $0.055^{* * *}$ & $0.071^{* * *}$ & $0.070 * * *$ \\
\hline & $(0.012)$ & $(0.012)$ & $(0.021)$ & $(0.020)$ & $(0.022)$ & $(0.022)$ \\
\hline \multirow{2}{*}{$\log \left(\right.$ Employment $\left._{\mathrm{c}}^{2000}\right)$} & $-0.005^{* * *}$ & $-0.006^{* * *}$ & $\ldots$ & $\ldots$ & $\cdots$ & $\cdots$ \\
\hline & $(0.002)$ & $(0.002)$ & & & & \\
\hline \multirow[t]{2}{*}{$\log \left(\right.$ GDP Per Capita $\left.{ }_{\mathrm{c}}^{2000}\right)$} & $\cdots$ & $\cdots$ & $-0.018 * * * *$ & $-0.018 * * * *$ & $\cdots$ & $\cdots$ \\
\hline & & & $(0.003)$ & $(0.003)$ & & \\
\hline \multirow{2}{*}{$\log \left(\right.$ Labour Productivity $\left.{ }_{c}^{2000}\right)$} & $\ldots$ & $\ldots$ & $\ldots$ & $\ldots$ & $-0.018^{* * * *}$ & $-0.017 * * * *$ \\
\hline & & & & & $(0.003)$ & $(0.003)$ \\
\hline \multirow[t]{2}{*}{$\log \left(\right.$ Employment $\left.{ }_{c}^{\text {Avg. } 1991 \text { to 2000 }}\right)$} & $\ldots$ & $\cdots$ & $0.009 * * *$ & $0.009 * * * *$ & $0.011 * * * *$ & $0.011^{* * * *}$ \\
\hline & & & $(0.003)$ & $(0.003)$ & $(0.003)$ & $(0.003)$ \\
\hline \multirow{2}{*}{$\log \left(\right.$ GDP Per Capita ${ }_{c}^{\text {Avg. } 1990 ~ t o ~ 2000) ~}$} & 0.001 & 0.000 & $\cdots$ & $\cdots$ & $\cdots$ & $\cdots$ \\
\hline & $(0.002)$ & $(0.002)$ & & & & \\
\hline \multirow[t]{2}{*}{ Gross Fixed Capital Formation to GDP ${ }_{c}^{\text {Avg. }} 1990$ to 2000} & -0.010 & -0.000 & 0.028 & 0.012 & 0.020 & 0.001 \\
\hline & $(0.026)$ & $(0.025)$ & $(0.036)$ & $(0.034)$ & $(0.037)$ & $(0.036)$ \\
\hline \multirow[t]{2}{*}{ 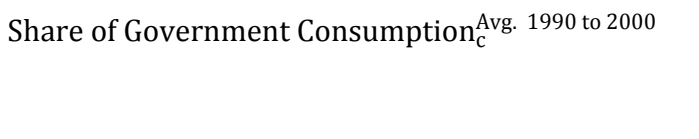 } & -0.008 & -0.009 & -0.019 & -0.018 & -0.017 & -0.017 \\
\hline & $(0.015)$ & $(0.015)$ & $(0.026)$ & $(0.026)$ & $(0.024)$ & $(0.024)$ \\
\hline \multirow[t]{2}{*}{ Oil Rent to GDP Avg. 1990 to 2000} & $0.030^{*}$ & $0.026^{*}$ & 0.020 & 0.027 & 0.010 & 0.019 \\
\hline & $(0.016)$ & $(0.016)$ & $(0.025)$ & $(0.025)$ & $(0.024)$ & $(0.025)$ \\
\hline \multirow[t]{2}{*}{ Openess Avg. 1990 to 2000} & $0.010^{* *}$ & $0.010^{* *}$ & $0.014 * * *$ & $0.014 * * *$ & 0.009 & $0.010^{*}$ \\
\hline & $(0.005)$ & $(0.005)$ & $(0.005)$ & $(0.005)$ & $(0.006)$ & $(0.006)$ \\
\hline \multirow[t]{2}{*}{ Share of High Tech Export Avg. 1990 to 2000} & 0.005 & 0.007 & $-0.019 *$ & $-0.022 *$ & -0.011 & -0.013 \\
\hline & $(0.009)$ & $(0.009)$ & $(0.012)$ & $(0.012)$ & $(0.014)$ & $(0.014)$ \\
\hline \multirow[t]{2}{*}{ High Income $_{c}(\mathrm{~d})$} & -0.002 & -0.002 & $0.016^{* * *}$ & $0.016^{* * *}$ & $0.013 * *$ & $0.013 * *$ \\
\hline & $(0.003)$ & $(0.003)$ & $(0.005)$ & $(0.005)$ & $(0.005)$ & $(0.005)$ \\
\hline \multirow[t]{2}{*}{ Population Densityc Avg. 1990 to 2000} & 0.000 & 0.000 & 0.000 & 0.000 & -0.000 & -0.000 \\
\hline & $(0.000)$ & $(0.000)$ & $(0.000)$ & $(0.000)$ & $(0.000)$ & $(0.000)$ \\
\hline
\end{tabular}




\begin{tabular}{|c|c|c|c|c|c|c|}
\hline \multirow[t]{2}{*}{ Years of Schooling Avg. 1990, 1995, 2000} & $-0.002 * *$ & $-0.002 * *$ & $0.003 * * *$ & $0.004 * * *$ & $0.004 * * *$ & $0.004 * * *$ \\
\hline & $(0.001)$ & $(0.001)$ & $(0.001)$ & $(0.001)$ & $(0.001)$ & $(0.001)$ \\
\hline \multirow[t]{2}{*}{ Government Effectiveness $s_{c}^{\text {Avg. }}$ 1996, 1998, 2000} & 0.002 & 0.001 & 0.003 & 0.004 & 0.002 & 0.003 \\
\hline & $(0.002)$ & $(0.002)$ & $(0.003)$ & $(0.003)$ & $(0.003)$ & $(0.003)$ \\
\hline \multirow{2}{*}{$\log \left(\right.$ Surface $\left._{c}\right)$} & $0.002 * *$ & $0.002^{* *}$ & 0.002 & 0.002 & 0.002 & 0.002 \\
\hline & $(0.001)$ & $(0.001)$ & $(0.002)$ & $(0.002)$ & $(0.002)$ & $(0.002)$ \\
\hline \multirow[t]{2}{*}{$\operatorname{Island}_{c}(\mathrm{~d})$} & -0.000 & -0.001 & -0.001 & 0.000 & -0.001 & 0.001 \\
\hline & $(0.003)$ & $(0.003)$ & $(0.005)$ & $(0.005)$ & $(0.005)$ & $(0.005)$ \\
\hline \multirow{2}{*}{ Landlocked $_{c}(\mathrm{~d})$} & 0.003 & 0.003 & -0.003 & -0.003 & -0.006 & -0.005 \\
\hline & $(0.002)$ & $(0.002)$ & $(0.004)$ & $(0.004)$ & $(0.004)$ & $(0.004)$ \\
\hline \multirow{2}{*}{ Latitude $_{c}$} & -0.000 & -0.000 & 0.000 & 0.000 & 0.000 & 0.000 \\
\hline & $(0.000)$ & $(0.000)$ & $(0.000)$ & $(0.000)$ & $(0.000)$ & $(0.000)$ \\
\hline \multirow[t]{2}{*}{ Longitude $_{c}$} & -0.000 & -0.000 & -0.000 & $-0.000^{*}$ & $-0.000 * *$ & $-0.000 * * *$ \\
\hline & $(0.000)$ & $(0.000)$ & $(0.000)$ & $(0.000)$ & $(0.000)$ & $(0.000)$ \\
\hline \multirow[t]{2}{*}{$\log \left(\right.$ GDP Per Capita $\left.{ }_{c}^{1900}\right)$} & $\ldots$ & $0.003^{*}$ & $\ldots$ & $-0.004 * *$ & $\cdots$ & $-0.005^{* *}$ \\
\hline & & $(0.001)$ & & $(0.002)$ & & $(0.002)$ \\
\hline Macro-Region Dummies & Yes & Yes & Yes & Yes & Yes & Yes \\
\hline Number of Countries & 108 & 108 & 108 & 108 & 108 & 108 \\
\hline $\mathrm{R}^{2}$ & 0.64 & 0.65 & 0.52 & 0.54 & 0.47 & 0.49 \\
\hline \multirow[t]{2}{*}{ Model F Statistic [p-value] } & $14.98[0.000]$ & $16.58[0.000]$ & $12.89[0.000]$ & $12.73[0.000]$ & $12.11[0.000]$ & $11.44[0.000]$ \\
\hline & & & & & & \\
\hline \multirow[t]{2}{*}{ Area Equipped for Irrigation ${ }_{c}^{1900}$} & $0.202 * * * *$ & $0.203^{* * * *}$ & $0.205^{* * * *}$ & $0.205^{* * * *}$ & $0.205^{* * * *}$ & $0.206^{* * * *}$ \\
\hline & $(0.042)$ & $(0.043)$ & $(0.039)$ & $(0.039)$ & $(0.043)$ & $(0.043)$ \\
\hline \multirow[t]{2}{*}{ Terrain Ruggedness $_{c}$} & -0.002 & -0.002 & -0.002 & -0.002 & -0.002 & -0.002 \\
\hline & $(0.002)$ & $(0.002)$ & $(0.002)$ & $(0.002)$ & $(0.002)$ & $(0.002)$ \\
\hline First-Stage F Statistic on Excluded IVs [p-value] & $12.88[0.000]$ & $12.66[0.000]$ & $15.02[0.000]$ & $14.95[0.000]$ & $12.64[0.000]$ & $12.56[0.000]$ \\
\hline Hansen J Statistic (p-value) & 0.513 & 0.548 & 0.571 & 0.621 & 0.170 & 0.222 \\
\hline
\end{tabular}


Table C9: The economic returns of urban concentration - Robustness test on TSLS estimates using an over-identified equation with historical urban land coverage and controlling for historical economic development level.

\begin{tabular}{|c|c|c|c|c|c|c|}
\hline \multirow[t]{2}{*}{ Dependent Variable } & \multicolumn{2}{|c|}{ 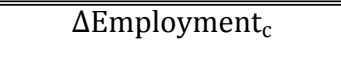 } & \multicolumn{2}{|c|}{ 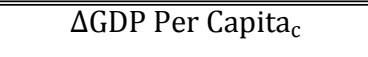 } & \multicolumn{2}{|c|}{ 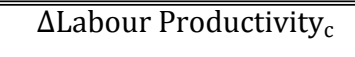 } \\
\hline & (1) & (2) & (3) & (4) & (5) & (6) \\
\hline \multirow[t]{2}{*}{ Urban Concentration $_{\mathrm{c}}^{2000}$} & $-0.027^{*}$ & $-0.026^{*}$ & $0.055^{* * * *}$ & $0.053^{* * * *}$ & $0.076^{* * * *}$ & $0.074 * * * *$ \\
\hline & $(0.016)$ & $(0.016)$ & $(0.016)$ & $(0.015)$ & $(0.017)$ & $(0.017)$ \\
\hline \multirow{2}{*}{$\log \left(\right.$ Employment $\left._{\mathrm{c}}^{2000}\right)$} & $-0.005^{* *}$ & $-0.005^{* *}$ & $\ldots$ & $\ldots$ & $\ldots$ & $\ldots$ \\
\hline & $(0.002)$ & $(0.002)$ & & & & \\
\hline \multirow[t]{2}{*}{$\log \left(\right.$ GDP Per Capita $\left.{ }_{c}^{2000}\right)$} & $\ldots$ & $\ldots$ & $-0.018^{* * * *}$ & $-0.018 * * * *$ & $\ldots$ & $\ldots$ \\
\hline & & & $(0.003)$ & $(0.003)$ & & \\
\hline \multirow{2}{*}{$\log \left(\right.$ Labour Productivity $\left.{ }_{c}^{2000}\right)$} & $\ldots$ & $\ldots$ & $\ldots$ & $\ldots$ & $-0.018 * * * *$ & $-0.017 * * * *$ \\
\hline & & & & & $(0.003)$ & $(0.003)$ \\
\hline \multirow[t]{2}{*}{ 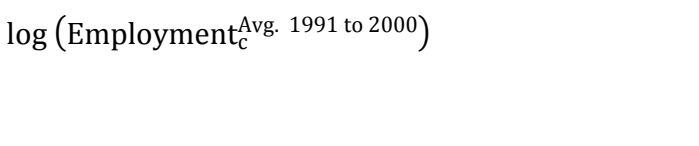 } & $\ldots$ & $\ldots$ & $0.009 * * *$ & $0.009 * * * *$ & $0.011^{* * * *}$ & $0.012 * * * *$ \\
\hline & & & $(0.003)$ & $(0.003)$ & $(0.003)$ & $(0.003)$ \\
\hline \multirow{2}{*}{$\log \left(\right.$ GDP Per Capita ${ }_{\mathrm{c}}^{\text {Avg. } 1990 \text { to } 2000)}$} & 0.001 & 0.000 & $\cdots$ & $\cdots$ & $\cdots$ & $\cdots$ \\
\hline & $(0.002)$ & $(0.002)$ & & & & \\
\hline \multirow{2}{*}{ Gross Fixed Capital Formation to GDP Avg. 1990 to 2000} & -0.010 & -0.000 & 0.028 & 0.013 & 0.020 & 0.000 \\
\hline & $(0.026)$ & $(0.026)$ & $(0.036)$ & $(0.034)$ & $(0.038)$ & $(0.036)$ \\
\hline \multirow[t]{2}{*}{ 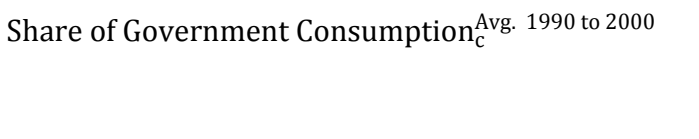 } & -0.008 & -0.009 & -0.018 & -0.018 & -0.018 & -0.018 \\
\hline & $(0.015)$ & $(0.015)$ & $(0.025)$ & $(0.026)$ & $(0.024)$ & $(0.025)$ \\
\hline \multirow[t]{2}{*}{ Oil Rent to GDP Avg. 1990 to 2000} & $0.030^{*}$ & 0.026 & 0.020 & 0.026 & 0.013 & 0.021 \\
\hline & $(0.016)$ & $(0.016)$ & $(0.025)$ & $(0.025)$ & $(0.025)$ & $(0.025)$ \\
\hline \multirow[t]{2}{*}{ Openess ${ }_{c}^{\text {Avg. } 1990 ~ t o ~} 2000$} & $0.010 * *$ & $0.010 * *$ & $0.014 * * *$ & $0.014 * * *$ & 0.009 & $0.010^{*}$ \\
\hline & $(0.005)$ & $(0.005)$ & $(0.005)$ & $(0.005)$ & $(0.006)$ & $(0.006)$ \\
\hline \multirow[t]{2}{*}{ Share of High Tech Export $t_{c}^{\text {Avg. }} 1990$ to 2000} & 0.005 & 0.007 & $-0.019 *$ & $-0.022 *$ & -0.011 & -0.014 \\
\hline & $(0.010)$ & $(0.010)$ & $(0.012)$ & $(0.011)$ & $(0.014)$ & $(0.014)$ \\
\hline \multirow[t]{2}{*}{$\operatorname{High~Income~}_{c}(\mathrm{~d})$} & -0.002 & -0.002 & $0.016^{* * *}$ & $0.016^{* * *}$ & $0.013 * *$ & $0.013^{* *}$ \\
\hline & $(0.003)$ & $(0.003)$ & $(0.005)$ & $(0.005)$ & $(0.005)$ & $(0.005)$ \\
\hline \multirow[t]{2}{*}{ Population Density Avg. 1990 to 2000} & 0.000 & 0.000 & 0.000 & 0.000 & -0.000 & -0.000 \\
\hline & $(0.000)$ & $(0.000)$ & $(0.000)$ & $(0.000)$ & $(0.000)$ & $(0.000)$ \\
\hline
\end{tabular}




\begin{tabular}{|c|c|c|c|c|c|c|}
\hline \multirow[t]{2}{*}{ Years of Schooling Avg. 1990, 1995, 2000} & $-0.002 * *$ & $-0.002 * *$ & $0.003 * * *$ & $0.004 * * *$ & $0.004 * * *$ & $0.004 * * * *$ \\
\hline & $(0.001)$ & $(0.001)$ & $(0.001)$ & $(0.001)$ & $(0.001)$ & $(0.001)$ \\
\hline \multirow[t]{2}{*}{ Government Effectiveness $s_{c}^{\text {Avg. }}$ 1996, 1998, 2000} & 0.002 & 0.001 & 0.003 & 0.004 & 0.002 & 0.003 \\
\hline & $(0.002)$ & $(0.002)$ & $(0.003)$ & $(0.003)$ & $(0.003)$ & $(0.003)$ \\
\hline \multirow[t]{2}{*}{$\log \left(\right.$ Surface $\left._{c}\right)$} & $0.002 *$ & $0.002 * *$ & 0.002 & 0.002 & 0.002 & 0.002 \\
\hline & $(0.001)$ & $(0.001)$ & $(0.002)$ & $(0.002)$ & $(0.002)$ & $(0.002)$ \\
\hline \multirow[t]{2}{*}{$\operatorname{Island}_{c}(\mathrm{~d})$} & -0.000 & -0.001 & -0.001 & 0.000 & -0.001 & 0.001 \\
\hline & $(0.003)$ & $(0.003)$ & $(0.005)$ & $(0.005)$ & $(0.005)$ & $(0.005)$ \\
\hline \multirow[t]{2}{*}{ Landlocked $_{c}$ (d) } & 0.003 & 0.003 & -0.003 & -0.003 & -0.006 & -0.005 \\
\hline & $(0.002)$ & $(0.002)$ & $(0.004)$ & $(0.004)$ & $(0.004)$ & $(0.004)$ \\
\hline \multirow[t]{2}{*}{ Latitude $_{c}$} & -0.000 & -0.000 & 0.000 & 0.000 & 0.000 & 0.000 \\
\hline & $(0.000)$ & $(0.000)$ & $(0.000)$ & $(0.000)$ & $(0.000)$ & $(0.000)$ \\
\hline \multirow[t]{2}{*}{ Longitude $_{c}$} & -0.000 & -0.000 & -0.000 & $-0.000 *$ & $-0.000 * * *$ & $-0.000 * * *$ \\
\hline & $(0.000)$ & $(0.000)$ & $(0.000)$ & $(0.000)$ & $(0.000)$ & $(0.000)$ \\
\hline \multirow[t]{2}{*}{$\log \left(\right.$ GDP Per Capita $\left.{ }_{c}^{1900}\right)$} & $\ldots$ & $0.003^{*}$ & $\ldots$ & $-0.004 * *$ & $\ldots$ & $-0.005 * *$ \\
\hline & & $(0.001)$ & & $(0.002)$ & & $(0.003)$ \\
\hline Macro-Region Dummies & Yes & Yes & Yes & Yes & Yes & Yes \\
\hline Number of Countries & 108 & 108 & 108 & 108 & 108 & 108 \\
\hline $\mathrm{R}^{2}$ & 0.64 & 0.65 & 0.52 & 0.54 & 0.44 & 0.47 \\
\hline Model F Statistic [p-value] & $15.46[0.000]$ & $16.79[0.000]$ & $13.39[0.000]$ & $13.19[0.000]$ & $14.01[0.000]$ & $12.58[0.000]$ \\
\hline
\end{tabular}

\section{First-Stage Estimation}

\begin{tabular}{|c|c|c|c|c|c|c|}
\hline \multirow[t]{2}{*}{ Area Equipped for Irrigation ${ }_{\mathrm{c}}^{1900}$} & $0.191 * * * *$ & $0.192 * * * *$ & $0.194 * * * *$ & $0.195 * * * *$ & $0.194 * * * *$ & $0.195^{* * * *}$ \\
\hline & $(0.044)$ & $(0.044)$ & $(0.040)$ & $(0.041)$ & $(0.044)$ & $(0.045)$ \\
\hline \multirow[t]{2}{*}{ Share Urban Land $d_{c}^{1881}$} & $-0.147^{*}$ & $-0.150^{*}$ & $-0.146^{*}$ & $-0.149 *$ & $-0.155^{* *}$ & $-0.157^{*}$ \\
\hline & $(0.079)$ & $(0.082)$ & $(0.078)$ & $(0.082)$ & $(0.078)$ & $(0.081)$ \\
\hline First-Stage F Statistic on Excluded IVs [p-value] & $12.92[0.000]$ & $12.74[0.000]$ & $15.05[0.000]$ & $14.90[0.000]$ & $12.79[0.000]$ & $12.68[0.000]$ \\
\hline Hansen J Statistic (p-value) & 0.719 & 0.700 & 0.417 & 0.371 & 0.306 & 0.309 \\
\hline
\end{tabular}

Notes: $* p<0.1 ; * * p<0.05 ; * * * p<0.01 ; * * * * p<0.001$. TSLS estimates. Robust standard errors are reported in parentheses. All specifications include a constant term. (d) denotes a binary variable. Table A2 (Online Appendix A) reports the definition of the variables. The full set of first-stage estimates is available upon request. 
Table C10: The economic returns of urban concentration - Robustness test on TSLS estimates trimming top and bottom 5\% and $10 \%$ of FUAs by population.

\begin{tabular}{|c|c|c|c|c|c|c|}
\hline \multirow{2}{*}{$\begin{array}{l}\text { Trimming Top and Bottom } x \% \text { of FUAs } \\
\text { Dependent Variable }\end{array}$} & \multicolumn{3}{|c|}{$x=5 \%$} & \multicolumn{3}{|c|}{$x=10 \%$} \\
\hline & $\Delta$ Employment $_{\mathrm{c}}$ & $\Delta$ GDP Per Capita ${ }_{c}$ & $\Delta$ Labour Productivity $_{\mathrm{c}}$ & $\Delta$ Employment $_{\mathrm{c}}$ & $\Delta$ GDP Per Capita ${ }_{c}$ & $\Delta$ Labour Productivity $_{c}$ \\
\hline \multirow{3}{*}{ Urban Concentration $_{c}^{2000}$} & (1) & (2) & (3) & (4) & (5) & (6) \\
\hline & $-0.018^{* *}$ & $0.036^{* * *}$ & $0.051^{* * * *}$ & $-0.031^{* * * *}$ & $0.044 * * * *$ & $0.063^{* * * *}$ \\
\hline & $(0.008)$ & $(0.011)$ & $(0.012)$ & $(0.008)$ & $(0.012)$ & $(0.012)$ \\
\hline \multirow[t]{2}{*}{$\log \left(\right.$ Employment $\left._{c}^{2000}\right)$} & $-0.004 * * *$ & $\ldots$ & $\ldots$ & $-0.004 * * *$ & $\ldots$ & $\ldots$ \\
\hline & $(0.001)$ & & & $(0.001)$ & & \\
\hline \multirow[t]{2}{*}{$\log \left(\right.$ GDP Per Capita $\left.{ }_{c}^{2000}\right)$} & $\ldots$ & $-0.016^{* * * *}$ & $\ldots$ & $\ldots$ & $-0.017^{* * * *}$ & $\ldots$ \\
\hline & & $(0.003)$ & & & $(0.003)$ & \\
\hline \multirow[t]{2}{*}{$\log \left(\right.$ Labour Productivity $\left.{ }_{c}^{2000}\right)$} & $\ldots$ & $\ldots$ & $-0.015^{* * * *}$ & $\ldots$ & $\ldots$ & $-0.015^{* * * *}$ \\
\hline & & & $(0.003)$ & & & $(0.003)$ \\
\hline \multirow[t]{2}{*}{$\log \left(\right.$ Employment ${ }_{c}^{\text {Avg. }} 1991$ to 2000$)$} & $\ldots$ & $0.007 * * * *$ & $0.009^{* * * *}$ & $\ldots$ & $0.006^{* * *}$ & $0.008^{* * * *}$ \\
\hline & & $(0.002)$ & $(0.002)$ & & $(0.002)$ & $(0.002)$ \\
\hline \multirow[t]{2}{*}{$\log \left(\right.$ GDP Per Capita avg. $_{c}^{\text {Avg. }} 1990$ to 2000$)$} & 0.000 & $\ldots$ & $\ldots$ & -0.003 & $\ldots$ & $\ldots$ \\
\hline & $(0.002)$ & & & $(0.002)$ & & \\
\hline \multirow[t]{2}{*}{ Gross Fixed Capital Formation to GDP Avg. 1990 to 2000} & -0.019 & 0.046 & 0.042 & -0.015 & $0.059^{*}$ & $0.050^{*}$ \\
\hline & $(0.024)$ & $(0.032)$ & $(0.031)$ & $(0.022)$ & $(0.032)$ & $(0.030)$ \\
\hline Share of Government Consumption ${ }_{c}^{\text {Avg. }} 1990$ to 2000 & -0.010 & -0.012 & -0.011 & -0.019 & -0.005 & -0.001 \\
\hline
\end{tabular}




\begin{tabular}{|c|c|c|c|c|c|c|}
\hline \multirow[t]{2}{*}{ Oil Rent to GDP $_{c}^{\text {Avg. }} 1990$ to 2000} & $0.047 * * *$ & -0.018 & $-0.039^{*}$ & $0.075^{* * * *}$ & -0.041 & $-0.074^{*}$ \\
\hline & $(0.015)$ & $(0.022)$ & $(0.021)$ & $(0.021)$ & $(0.033)$ & $(0.039)$ \\
\hline \multirow[t]{2}{*}{ Openess $s_{c}^{\text {Avg. }} 1990$ to 2000} & $0.011^{* *}$ & $0.011^{* *}$ & 0.006 & $0.009 * *$ & 0.006 & 0.003 \\
\hline & $(0.005)$ & $(0.005)$ & $(0.006)$ & $(0.004)$ & $(0.005)$ & $(0.005)$ \\
\hline \multirow[t]{2}{*}{ Share of High Tech Export Avg. 1990 to 2000} & 0.004 & $-0.016^{*}$ & -0.007 & $0.014^{*}$ & -0.019 & -0.013 \\
\hline & $(0.008)$ & $(0.010)$ & $(0.011)$ & $(0.009)$ & $(0.011)$ & $(0.013)$ \\
\hline \multirow[t]{2}{*}{ High Income $_{c}(d)$} & -0.001 & $0.014^{* * *}$ & $0.010^{* *}$ & 0.001 & $0.015^{* * *}$ & $0.010^{*}$ \\
\hline & $(0.003)$ & $(0.005)$ & $(0.005)$ & $(0.003)$ & $(0.005)$ & $(0.005)$ \\
\hline \multirow[t]{2}{*}{ Population Densityc Avg. 1990 to 2000} & 0.000 & -0.000 & -0.000 & 0.000 & -0.000 & -0.000 \\
\hline & $(0.000)$ & $(0.000)$ & $(0.000)$ & $(0.000)$ & $(0.000)$ & $(0.000)$ \\
\hline \multirow[t]{2}{*}{ Years of Schooling Avg. 1990, 1995, 2000} & $-0.001^{*}$ & $0.003^{* * *}$ & $0.003 * * * *$ & -0.001 & $0.003 * * *$ & $0.003 * * *$ \\
\hline & $(0.001)$ & $(0.001)$ & $(0.001)$ & $(0.001)$ & $(0.001)$ & $(0.001)$ \\
\hline \multirow[t]{2}{*}{ Government Effectiveness $s_{c}^{\text {Avg. }}$ 1996, 1998, 2000} & 0.002 & 0.002 & 0.001 & 0.003 & 0.003 & 0.001 \\
\hline & $(0.002)$ & $(0.003)$ & $(0.003)$ & $(0.002)$ & $(0.003)$ & $(0.003)$ \\
\hline \multirow[t]{2}{*}{$\log \left(\right.$ Surface $\left._{c}\right)$} & $0.003^{* *}$ & 0.001 & 0.001 & 0.001 & 0.002 & 0.002 \\
\hline & $(0.001)$ & $(0.002)$ & $(0.002)$ & $(0.001)$ & $(0.002)$ & $(0.002)$ \\
\hline \multirow[t]{2}{*}{ Island $_{c}(\mathrm{~d})$} & -0.000 & 0.000 & 0.000 & -0.002 & 0.000 & 0.002 \\
\hline & $(0.003)$ & $(0.004)$ & $(0.004)$ & $(0.002)$ & $(0.005)$ & $(0.005)$ \\
\hline \multirow[t]{2}{*}{ Landlocked $_{c}(\mathrm{~d})$} & 0.003 & -0.003 & -0.005 & 0.003 & -0.004 & -0.006 \\
\hline & $(0.002)$ & $(0.004)$ & $(0.004)$ & $(0.002)$ & $(0.004)$ & $(0.004)$ \\
\hline
\end{tabular}




\begin{tabular}{|c|c|c|c|c|c|c|}
\hline \multirow[t]{2}{*}{ Latitude $_{c}$} & -0.000 & 0.000 & 0.000 & -0.000 & 0.000 & 0.000 \\
\hline & $(0.000)$ & $(0.000)$ & $(0.000)$ & $(0.000)$ & $(0.000)$ & $(0.000)$ \\
\hline \multirow[t]{2}{*}{ Longitude $_{c}$} & $-0.000^{*}$ & -0.000 & $-0.000^{* *}$ & -0.000 & -0.000 & $-0.000 *$ \\
\hline & $(0.000)$ & $(0.000)$ & $(0.000)$ & $(0.000)$ & $(0.000)$ & $(0.000)$ \\
\hline Macro-Region Dummies & Yes & Yes & Yes & Yes & Yes & Yes \\
\hline Number of Countries & 108 & 108 & 108 & 104 & 104 & 104 \\
\hline $\mathrm{R}^{2}$ & 0.66 & 0.59 & 0.55 & 0.67 & 0.56 & 0.49 \\
\hline \multirow[t]{2}{*}{ Model F Statistic [p-value] } & $19.01[0.000]$ & $12.85[0.000]$ & $13.87[0.000]$ & $11.78[0.000]$ & $13.16[0.000]$ & $11.80[0.000]$ \\
\hline & & & & & & \\
\hline \multirow[t]{2}{*}{ Area Equipped for Irrigation ${ }_{c}^{1900}$} & $0.335^{* * * *}$ & $0.336^{* * * *}$ & $0.333 * * * *$ & $0.300^{* * * *}$ & $0.303^{* * * *}$ & $0.302 * * * *$ \\
\hline & $(0.050)$ & $(0.047)$ & $(0.050)$ & $(0.055)$ & $(0.052)$ & $(0.053)$ \\
\hline First-Stage F Statistic on Excluded IV [p-value] & $44.75[0.000]$ & $51.22[0.000]$ & $44.12[0.000]$ & $29.34[0.000]$ & $33.44[0.000]$ & $32.01[0.000]$ \\
\hline
\end{tabular}

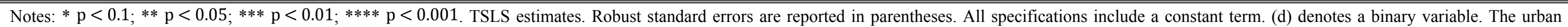

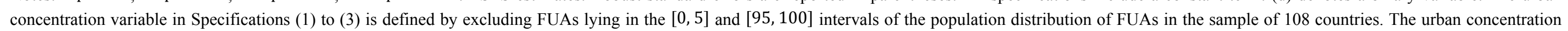

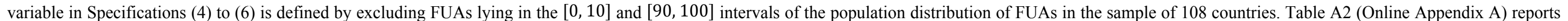
the definition of the variables. The full set of first-stage estimates is available upon request. 
Table C11: The economic returns of urban concentration - Robustness test on TSLS estimates considering the sub-sample of countries with a number of FUAs strictly greater than one.

\begin{tabular}{|c|c|c|c|}
\hline Dependent Variable & 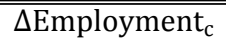 & 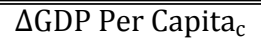 & 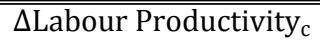 \\
\hline & (1) & (2) & (3) \\
\hline \multirow[t]{2}{*}{ Urban Concentration $_{c}^{2000}$} & $-0.057 * * *$ & $0.073 * *$ & $0.109 * * *$ \\
\hline & $(0.021)$ & $(0.032)$ & $(0.039)$ \\
\hline \multirow[t]{2}{*}{$\log \left(\right.$ Employment $\left._{c}^{2000}\right)$} & $-0.007 * * *$ & $\ldots$ & $\ldots$ \\
\hline & $(0.002)$ & & \\
\hline \multirow[t]{2}{*}{$\log \left(\right.$ GDP Per Capita $\left.{ }_{c}^{2000}\right)$} & $\cdots$ & $-0.020 * * * *$ & $\ldots$ \\
\hline & & $(0.004)$ & \\
\hline \multirow[t]{2}{*}{$\log \left(\right.$ Labour Productivity $\left.{ }_{c}^{2000}\right)$} & $\ldots$ & $\ldots$ & $-0.019 * * * *$ \\
\hline & & & $(0.004)$ \\
\hline \multirow[t]{2}{*}{$\log \left(\right.$ Employment $\left._{\mathrm{c}}^{\text {Avg. } 1991 \text { to } 2000}\right)$} & $\ldots$ & $0.008^{* *}$ & $0.012 * * *$ \\
\hline & & $(0.003)$ & $(0.004)$ \\
\hline \multirow[t]{2}{*}{$\log ($ GDP Per Capita Avg. 1990 to 2000) } & -0.002 & $\cdots$ & $\cdots$ \\
\hline & $(0.002)$ & & \\
\hline \multirow[t]{2}{*}{ Gross Fixed Capital Formation to GDP Avg. 1990 to 2000} & -0.000 & 0.038 & 0.021 \\
\hline & $(0.028)$ & $(0.040)$ & $(0.047)$ \\
\hline \multirow[t]{2}{*}{ 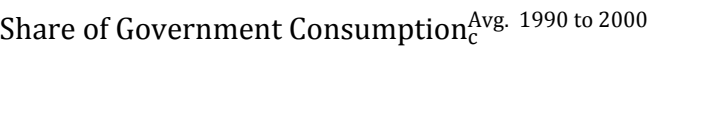 } & -0.008 & -0.019 & -0.020 \\
\hline & $(0.019)$ & $(0.032)$ & $(0.034)$ \\
\hline \multirow[t]{2}{*}{ Oil Rent to GDP Avg. 1990 to 2000} & $0.038^{*}$ & 0.029 & 0.020 \\
\hline & $(0.020)$ & $(0.031)$ & $(0.034)$ \\
\hline \multirow[t]{2}{*}{ 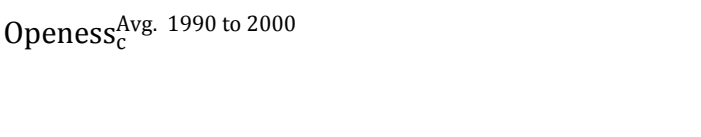 } & 0.004 & $0.011^{*}$ & 0.010 \\
\hline & $(0.005)$ & $(0.006)$ & $(0.007)$ \\
\hline \multirow[t]{2}{*}{ Share of High Tech Export ${ }_{c}^{\text {Avg. } 1990 ~ t o ~} 2000$} & $0.023^{*}$ & -0.026 & -0.026 \\
\hline & $(0.013)$ & $(0.017)$ & $(0.022)$ \\
\hline \multirow[t]{2}{*}{ High Income $_{c}(d)$} & 0.002 & $0.017 * *$ & 0.011 \\
\hline & $(0.004)$ & $(0.007)$ & $(0.008)$ \\
\hline \multirow[t]{2}{*}{ Population Density Avg. 1990 to 2000} & -0.000 & 0.000 & 0.000 \\
\hline & $(0.000)$ & $(0.000)$ & $(0.000)$ \\
\hline 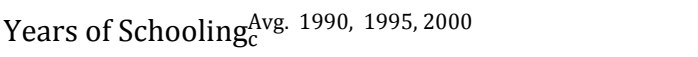 & $-0.002 *$ & $0.004 * * *$ & $0.004 * * *$ \\
\hline
\end{tabular}




\begin{tabular}{|c|c|c|c|}
\hline & $(0.001)$ & $(0.001)$ & $(0.001)$ \\
\hline \multirow[t]{2}{*}{ 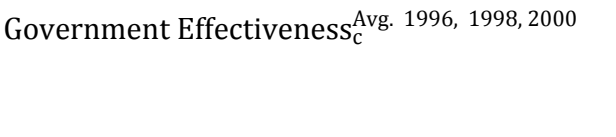 } & 0.004 & 0.005 & 0.002 \\
\hline & $(0.003)$ & $(0.004)$ & $(0.004)$ \\
\hline \multirow[t]{2}{*}{$\log \left(\right.$ Surface $\left._{c}\right)$} & 0.000 & 0.004 & 0.005 \\
\hline & $(0.002)$ & $(0.003)$ & $(0.003)$ \\
\hline \multirow[t]{2}{*}{ Island $_{c}(d)$} & -0.000 & -0.000 & 0.000 \\
\hline & $(0.004)$ & $(0.006)$ & $(0.007)$ \\
\hline \multirow[t]{2}{*}{ Landlocked $_{c}(\mathrm{~d})$} & 0.003 & -0.004 & -0.007 \\
\hline & $(0.003)$ & $(0.005)$ & $(0.006)$ \\
\hline \multirow[t]{2}{*}{ Latitude $_{c}$} & -0.000 & 0.000 & 0.000 \\
\hline & $(0.000)$ & $(0.000)$ & $(0.000)$ \\
\hline \multirow[t]{2}{*}{ Longitude $_{c}$} & -0.000 & -0.000 & $-0.000 * * *$ \\
\hline & $(0.000)$ & $(0.000)$ & $(0.000)$ \\
\hline Macro-Region Dummies & Yes & Yes & Yes \\
\hline Number of Countries & 102 & 102 & 102 \\
\hline $\mathrm{R}^{2}$ & 0.55 & 0.42 & 0.19 \\
\hline \multirow[t]{2}{*}{ Model F Statistic [p-value] } & $11.58[0.000]$ & $11.63[0.000]$ & $9.25[0.000]$ \\
\hline & & & \\
\hline \multirow[t]{2}{*}{ Area Equipped for Irrigation $_{c}^{1900}$} & $0.137 * * *$ & $0.145^{* * * *}$ & $0.142 * * * *$ \\
\hline & $(0.041)$ & $(0.040)$ & $(0.041)$ \\
\hline First-Stage F Statistic on Excluded IV [p-value] & $10.91[0.001]$ & $13.22[0.001]$ & $11.22[0.001]$ \\
\hline
\end{tabular}




\section{References in Online Appendix A}

Ahrend R, Lembcke AC and Schumann A (2017) The role of urban agglomerations for economic and productivity growth. International Productivity Monitor 32: 161-179.

Dijkstra L, Florczyk A, Freire S, Kemper T and Pesaresi M (2018) Applying the degree of urbanisation to the globe: A new harmonised definition reveals a different picture of global urbanisation. Conference Paper presented at $16^{\text {th }}$ Conference of the International Association of Official Statisticians (IAOS), OECD Headquarters, Paris, France, September 2018.

Feenstra R, Inklaar R and Timmer M (2015) The next generation of the Penn World Table. The American Economic Review 105(10): 3150-3182.

Geiger T and Frieler K (2018) Continuous national Gross Domestic Product (GDP) time series for 195 countries: Past observations (1850-2005) harmonized with future projections according the Shared Socio-economic Pathways (2006-2100). V. 2.0, Potsdam Institute for Climate Impact Research by GFZ Data Services.

Goldewijk KK, Beusen A and Janssen P (2010) Long term dynamic modeling of global population and built-up area in a spatially explicit way, HYDE 3.1. The Holocene 20(4): 565-573.

Goldewijk KK, Beusen A, van Drecht G and de Vos M (2011) The HYDE 3.1 spatially explicit database of human-induced global land-use change over the past 12,000 years. Global Ecology and Biogeography 20(1): 73-86.

Nunn N and Puga D (2012) Ruggedness: The blessing of bad geography in Africa. Review of Economics and Statistics 94(1): 20-36.

Siebert S, Kummu M, Porkka M, Döll P, Ramankutty N and Scanlon BR (2015) A global data set of the extent of irrigated land from 1900 to 2005. Hydrology and Earth System Science 19(3): $1521-1545$. 


\section{References in Online Appendix C}

Frick SA and Rodríguez-Pose A (2018) Change in urban concentration and economic growth. World Development 105: 156-170.

Geiger T and Frieler K (2018) Continuous national Gross Domestic Product (GDP) time series for 195 countries: Past observations (1850-2005) harmonized with future projections according the Shared Socio-economic Pathways (2006-2100). V. 2.0, Potsdam Institute for Climate Impact Research by GFZ Data Services.

Goldewijk KK, Beusen A and Janssen P (2010) Long term dynamic modeling of global population and built-up area in a spatially explicit way, HYDE 3.1. The Holocene 20(4): 565-573.

Goldewijk KK, Beusen A, van Drecht G and de Vos M (2011) The HYDE 3.1 spatially explicit database of human-induced global land-use change over the past 12,000 years. Global Ecology and Biogeography 20(1): 73-86.

Hansen LP (1982) Large sample properties of Generalized Method of Moments estimators. Econometrica 50(4): 1029-1054.

Nunn N and Puga D (2012) Ruggedness: The blessing of bad geography in Africa. Review of Economics and Statistics 94(1): 20-36. 